\title{
Adaptation of Coal Mine Floor Rating (CMFR) to Eastern U.S. Coal Mines
}

Sena Cicek

West Virginia University, sc0138@mix.wvu.edu

Follow this and additional works at: https://researchrepository.wvu.edu/etd

Part of the Mining Engineering Commons

\section{Recommended Citation}

Cicek, Sena, "Adaptation of Coal Mine Floor Rating (CMFR) to Eastern U.S. Coal Mines" (2020). Graduate Theses, Dissertations, and Problem Reports. 7843.

https://researchrepository.wvu.edu/etd/7843

This Thesis is protected by copyright and/or related rights. It has been brought to you by the The Research Repository @ WVU with permission from the rights-holder(s). You are free to use this Thesis in any way that is permitted by the copyright and related rights legislation that applies to your use. For other uses you must obtain permission from the rights-holder(s) directly, unless additional rights are indicated by a Creative Commons license in the record and/ or on the work itself. This Thesis has been accepted for inclusion in WVU Graduate Theses, Dissertations, and Problem Reports collection by an authorized administrator of The Research Repository @ WVU. For more information, please contact researchrepository@mail.wvu.edu. 


\title{
Adaptation of Coal Mine Floor Rating (CMFR) to Eastern U.S. Coal Mines
}

\author{
Sena Cicek
}

Thesis submitted to

the Benjamin M. Statler College of Engineering and Mineral Resources

at West Virginia University

in partial fulfillment of the requirements for the degree of

\author{
Master of Science \\ in \\ Mining Engineering
}

\author{
Ihsan Berk Tulu, Ph.D., Chair \\ Brijes Mishra, Ph.D. \\ Yi Luo, Ph.D. \\ Department of Mining Engineering \\ West Virginia University \\ Morgan M. Sears, Ph.D. \\ Pittsburgh Mining Research Division \\ National Institute for Occupational Safety and Health \\ Christopher Mark, Ph.D. \\ Mine Safety and Health Administration \\ Morgantown, West Virginia \\ 2020
}

Keywords: Rock mass classification, Coal Mine Floor Rating (CMFR), floor heave, buckling floor failure mechanism

Copyright 2020 Sena Cicek 


\section{ABSTRACT \\ Adaptation of Coal Mine Floor Rating (CMFR) to Eastern U.S. Coal Mines}

\section{Sena Cicek}

Floor heave — the excessive deformation and failure of floor strata—is a serious problem for many underground coal mining operations in the U.S. There is an accepted floor heave design methodology developed for the Illinois basin coal mines (Gadde, 2009). However, for Eastern U.S. coal mines in the Appalachian region, there is not any systematic design method to assess floor heave potential. In order to prevent stability problems associated with floor failure and to ensure the safety of the miners in this region, a systematic and proactive method to assess the potential of floor stability that also takes the floor failure mechanisms into consideration is a requirement.

In this study, the Coal Mine Floor Rating (CMFR) system, a rock mass classification system recently developed by Mo (2019) in Australia, which provides an indicator for the competence of floor strata is applied to Eastern U.S. coal mines that intermittently experienced floor heave. Exploratory geologic drill log data, overburden maps, and mine plans were gathered in a broad database for this study. Additionally, qualitative data (failure/non-failure) on floor conditions of the mine entries near the core holes were collected and analyzed so that the floor quality, and its relation to entry stability could be estimated by statistical methods.

This study found that the original CMFR classification system is not directly applicable in assessing the floor stability of Eastern U.S. coal mines. In order to extend the applicability of the CMFR classification system, the methodology is modified. A calculation procedure of the CMFR classification system's components, Coal Mine Floor Rating (CMFR) and Horizontal Stress Rating (HSR), is modified; additionally, new parameters were included in the HSR, such as orientation coefficient, horizontal stress magnitude, and elastic modulus of the strong floor layer. The stress distribution around pillars in the vicinity of the floor failure area is further analyzed through boundary element model software LaModel. After modifying the CMFR system, a better separation of failure and non-failure cases from one another is observed and an applicable rock mass classification system capable of predicting potential floor failures in the U.S. is proposed. 
To my family, 


\section{ACKNOWLEDGEMENTS}

First and foremost, I would like to express my profound appreciation and gratitude to my advisor, Dr. Ihsan Berk Tulu, for his greatest guidance, support, patience, and suggestion throughout this study. He has been an inspirational role model and mentor to me by providing invaluable directions and strong motivation. I am fortunate enough to have an opportunity to work under his supervision.

I would also like to express my deepest gratitude to Dr. Christopher Mark for guiding me to his important publications and for the stimulating questions on my research study. The discussions were crucial in inspiring me to think from multiple perspectives to form a comprehensive and objective critique. I would like to further extend my gratitude to other committee members Dr. Yi Luo, Dr. Brijes Mishra and, Dr. Morgan M. Sears for their encouragement and valuable contributions.

I gratefully acknowledge immense support from Dr. Serkan Saydam for giving me an opportunity to work in collaboration with his PhD student Sungsoon Mo and other professors at the University of New South Wales in Australia. Special thanks to Joe Wickline from Coronado Global Resources and Terry Hamrick from United Coal Company. My appreciation also extended to Dr. Michael Murphy and Dr. Brent Slaker for sharing their expertise and providing insightful advice on my research study.

Many thanks to Department Chair Dr. Vladislav Kecojevic for helping me grow professionally and advance my career. As well, I appreciate administrative support from Genette Chapman and Karen Centofanti during my academic pursuit. I would also take this opportunity to thank all my professors and fellow graduate students who made my stay such a memorable experience. I am also thankful to Rachel Boz Boothby, Sandra Morales Corales, Defne Dogu, and Elif Orhan for their caring friendship, love, and encouragement.

My final and utmost appreciation goes to my family as my biggest supporters at every stage of my life. I would like to specially thank my mother Banu Cevik, my father Cem Cicek, and my sister Zeynep Cicek for always being there for me. Also, I would like to thank my grandmother Meral Cevik, my grandfather Eyup Cevik, my uncle Ismail Cevik, and aunt Burcu Cevik for being my endless supporters; and my cousins Bartu Cevik and Emir Cevik for bringing joy to my life. 


\section{Table of Contents}

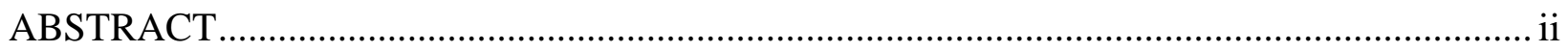

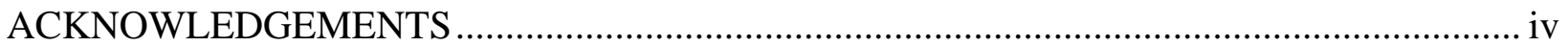

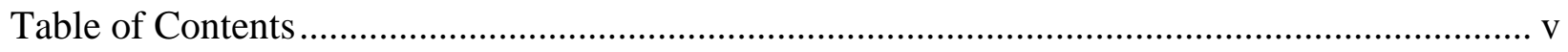

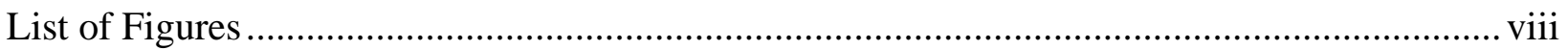

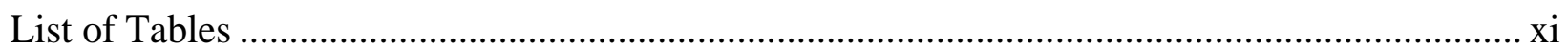

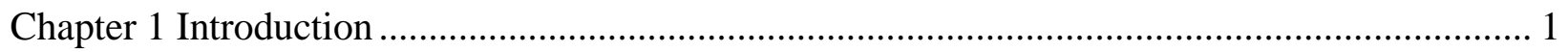

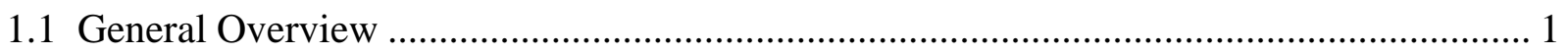

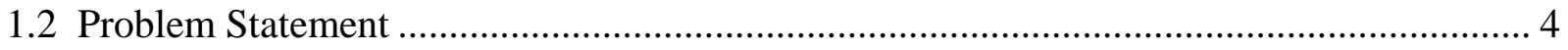

1.3 Objective of Thesis.................................................................................................... 5

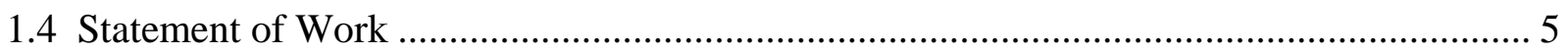

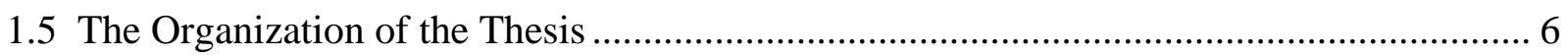

Chapter 2 Literature Review ............................................................................................ 7

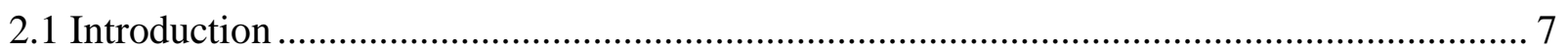

2.2 Floor Heave Mechanisms ........................................................................................... 7

2.2.1 Bearing Capacity Failure …………………......................................................... 9

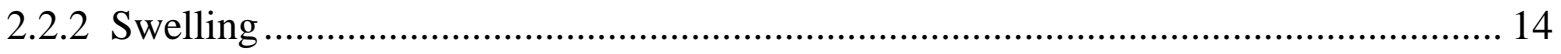

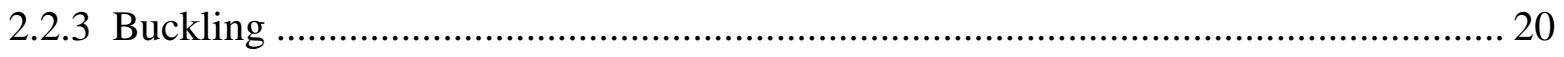

2.2.4 Other Floor Heave Mechanisms ............................................................................... 26

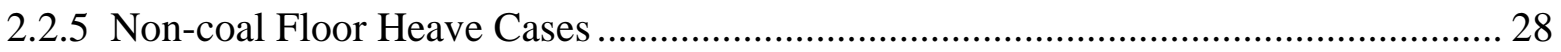

2.3 Rock Mass Classification Systems................................................................................... 32

2.4 Rock Mass Classification Systems in Mining ..................................................................... 34

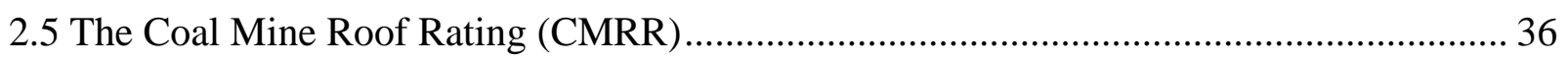


2.5.1 The CMRR Components and Calculation ...................................................... 37

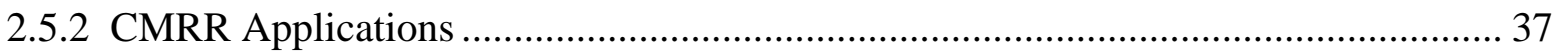

2.6 The Coal Mine Floor Rating (CMFR) ....................................................................... 38

2.6.1 The CMFR Components and Calculation ......................................................... 39

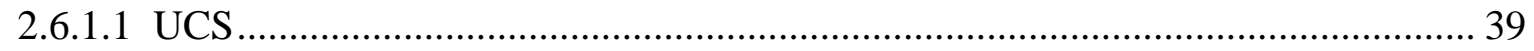

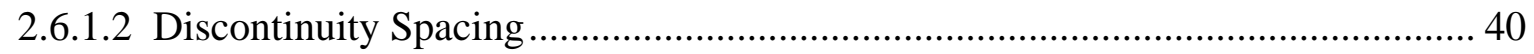

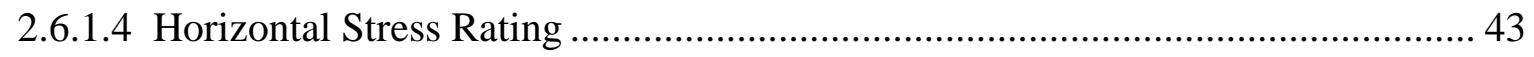

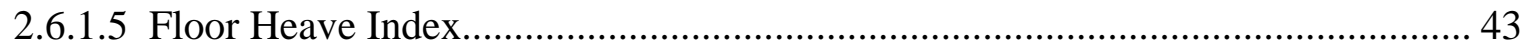

2.6.2 CMFR Application in Australia ................................................................. 44

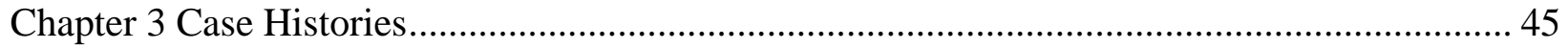

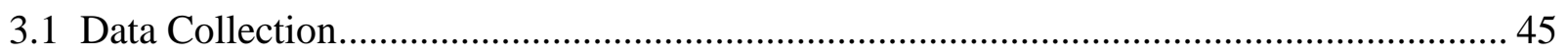

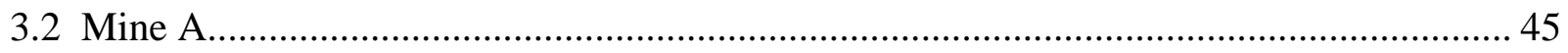

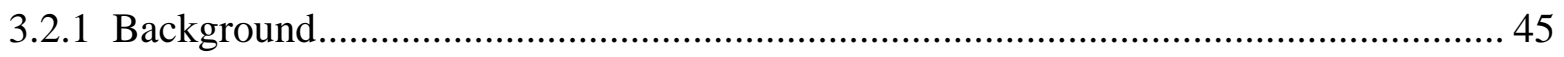

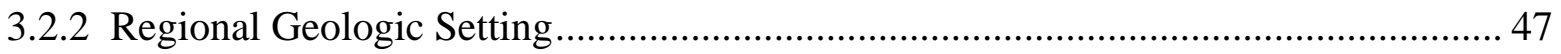

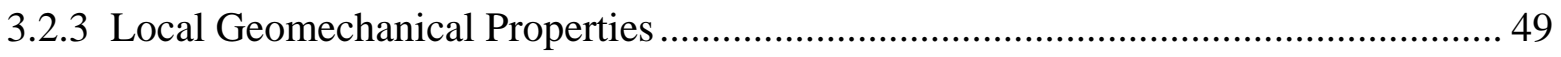

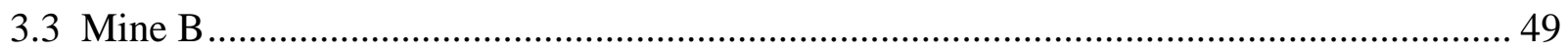

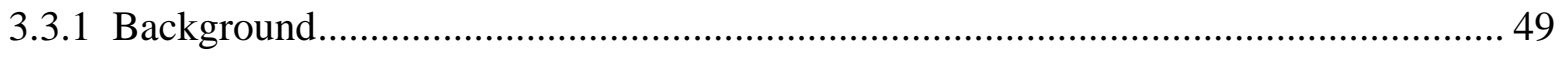

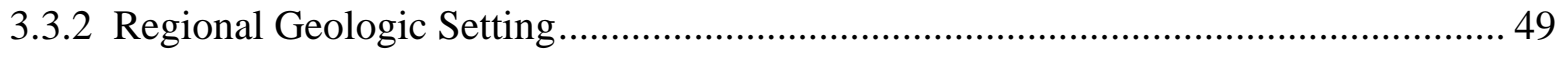

3.3.3 Local Geomechanical Properties ......................................................................... 50

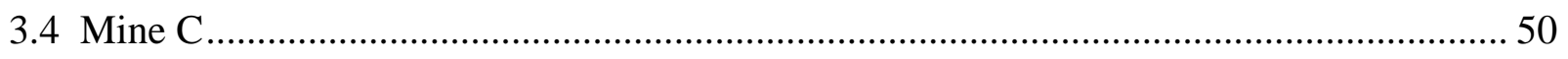

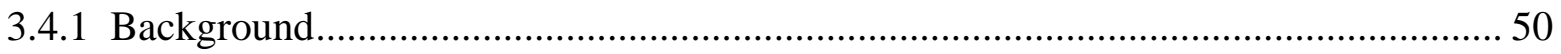

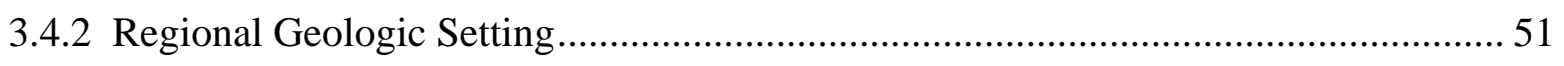

3.4.3 Local Geomechanical Properties .................................................................. 52 


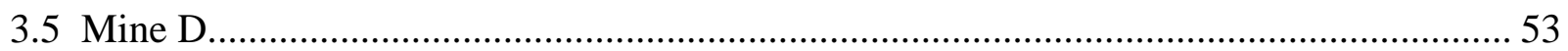

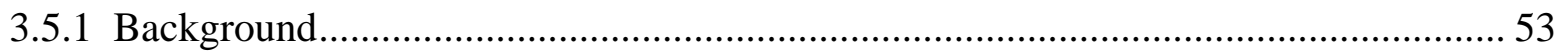

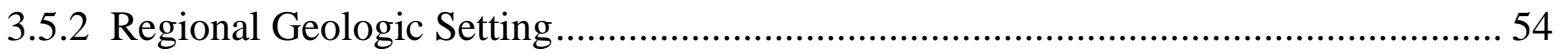

3.5.3 Local Geomechanical Properties .............................................................................. 55

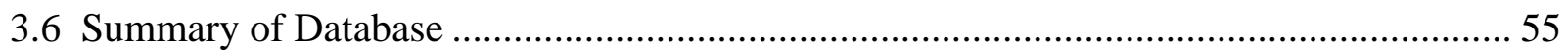

Chapter 4 Analysis of Eastern U.S. Database........................................................................... 57

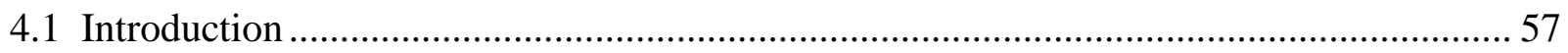

4.2 Application of the CMFR to the Eastern U.S. Case Histories ............................................ 57

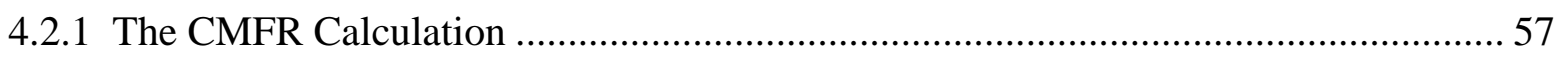

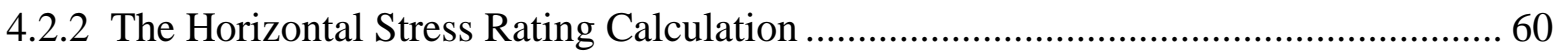

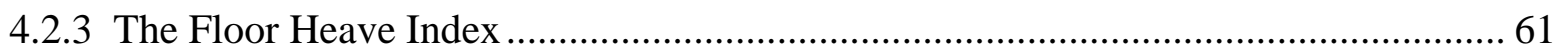

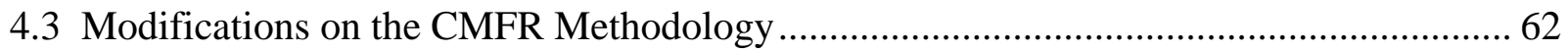

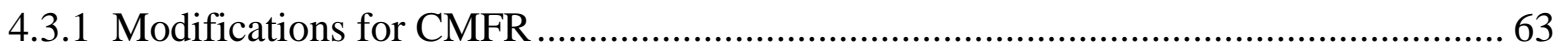

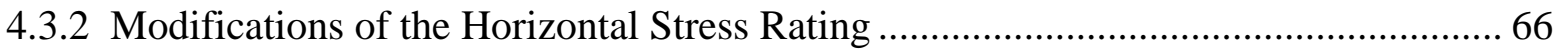

4.3.2.1 Modifications of the Depth Rating ………………………................................... 66

4.3.2.2 Modifications of the Angle Rating ......................................................................... 70

4.4 Re-analysis of cases based on Modified CMFR ............................................................. 72

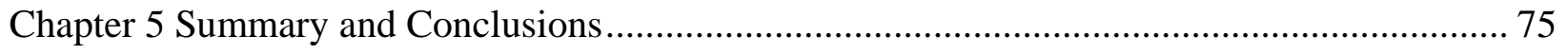

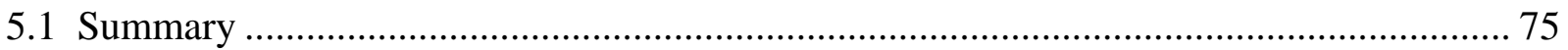

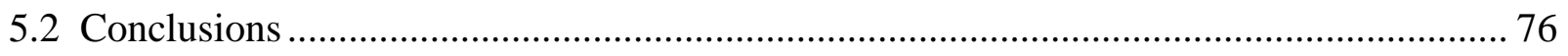

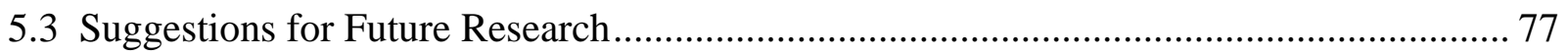

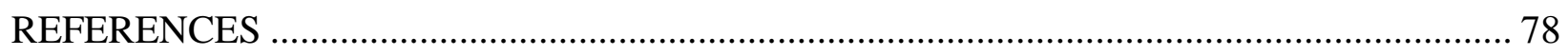

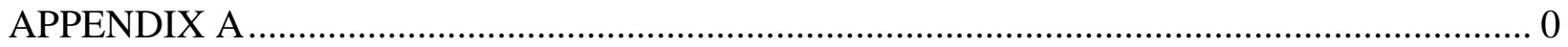




\section{List of Figures}

Figure 1. Floor deformation mechanisms: a) buckling by horizontal stress, b) swelling of underclay, c) deformation along shear planes, d) flow of underclay, and e) bearing capacity failure (adopted from Whittles, 1999).

Figure 2. Three principal mechanisms of floor heave: a) Bearing capacity failure, b) Swelling failure, and c) Buckling failure (Mo 2019) (adapted from Whittles et al., 2007). 9

Figure 3. Three modes of shear failure: a) punching shear failure, b) local shear failure, and c) general shear failure (adopted from Vesic, 1973)...................................................................... 11

Figure 4. Zeigler coal mine in the Illinois Basin: a) Initial floor deformation (Speck, 1979), and

b) Extensive floor heave in No. 5 mine (Speck, 1981)............................................................ 12

Figure 5. Localized floor heave area in No. 11 West Kentucky seam (Perry et al., 2015). ......... 13

Figure 6. Floor heave at Munmorah Colliery in Newcastle, Australia (Vasundhara,1999)......... 14

Figure 7. Claystone UCS variation with moisture content (Mills and Edwards, 1997). ............... 16

Figure 8. Partially closed entry due to gradual swelling (Gadde, 2009)........................................ 17

Figure 9. Floor heave due to combination of swelling and buckling heave at Cooranbong in

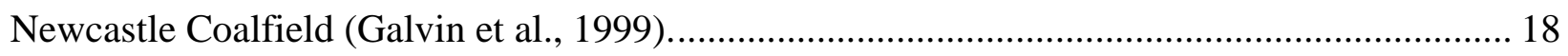

Figure 10. Buckling of floor strata due to swelling at Cooranbong in Newcastle Coalfield

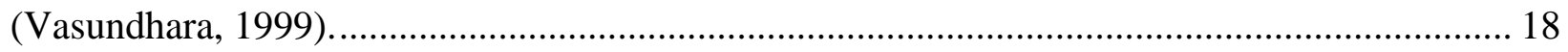

Figure 11. Stable pillar next to floor heave area in Cooranbong (Galvin et al., 1999).................. 19

Figure 12. Closed roadways in Kushiro coal mine in Japan due to significant plastic deformation

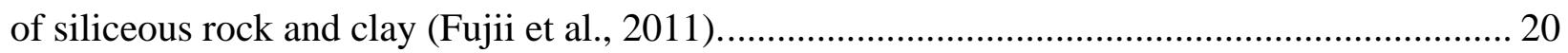

Figure 13. Floor heave sequence in Smoot mine, West Virginia (adopted from Peng, 1994)..... 21

Figure 14. Floor heave in Beckley coalbed: a) buckling of immediate floor into the entry, and b) immediate floor failure near the pillar (Aggson, 1978). 
Figure 15. Extreme buckling in an Alabama coal mine to the extent where the floor touched the roof (Serata et al., 1984). 23

Figure 16. Buckling of high-modulus sandstone floor in a lower mine during multiple-seam

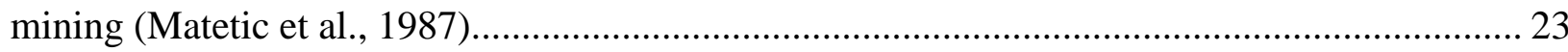

Figure 17. A rapid failure of a stiff immediate floor in a coal mine in Australia (Galvin, 2016). 25

Figure 18. Floor buckling in Springvale mine in Australia (Sheffield and Corbett, 2018)......... 25

Figure 19. Excessive floor failure in Blakefield South, NSW (Mo et al., 2018)........................ 26

Figure 20. Floor heave associated with rock burst (Qi et al., 2013) ....................................... 27

Figure 21. Floor and roof failure in trone beds in Wyoming: a) Roof-pillar-floor failure scheme (adopted Richardson et al., 1999) b) Floor heave as response to pillar punching (Richardson et

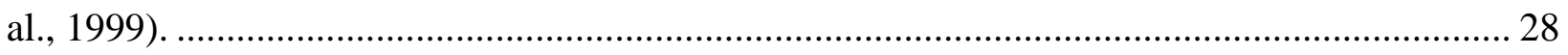

Figure 22. Surface subsidence in Petersburgh mine (Murphy, 2020)...................................... 29

Figure 23. Petersburgh mine pillars: a) Size reduction, and b) tension cracks (Murphy, 2020). . 30

Figure 24. Massive roof collapse in Petersburgh mine in Ohio (Murphy, 2020)...................... 30

Figure 25. Buckled floor in Subtropolis mine in Ohio (Slaker and Murphy, 2018)................... 31

Figure 26. Floor crack at Subtropolis mine (Slaker and Murphy, 2020)................................. 31

Figure 27. Floor Heave Index for Australian coal mines (adopted from Mo, 2019).................. 44

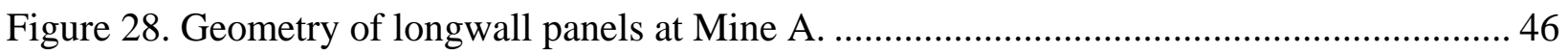

Figure 29. Stratigraphic nomenclature of the Lower Pennsylvanian Pocahontas Formation in southern West Virginia (Hennen, 1915, 1919; Krebs, 1916; Reger, 1926; Price, 1939) and southwestern Virginia (Englund, 1979; Nolde, 1994a, 1994b) (adopted from USGS, 2000)..... 47

Figure 30. Generalized stratigraphic column of the Pocahontas Number 3 coal seam for floor heave in the case study mine (Adopted from Van Dyke et al., 2018)..................................... 48

Figure 31. Stratigraphic column, showing the Eagle seam in Kanawha Group (Plass and Vogel,

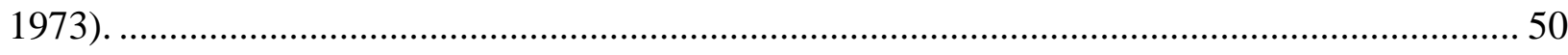


Figure 32. Mine C layout at floor heave area.

Figure 33. Floor rock samples at Mine C: a) Slickensided and rooted mudstone, b) Slickensided

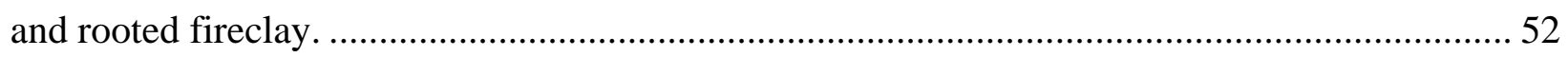

Figure 34. Mine D mine layout showing three-entry gateroad system.................................... 53

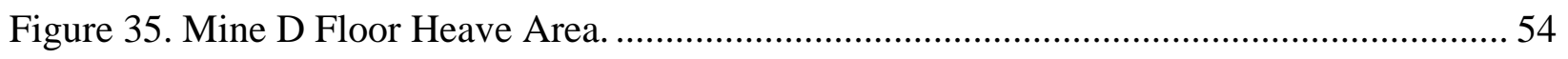

Figure 36. Generalized stratigraphic column, showing the groups and related coal beds (adopted

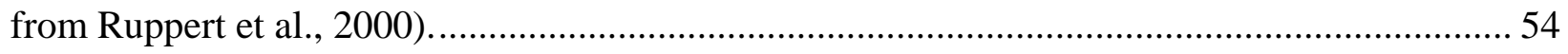

Figure 37. Discontinuity Counting on Drill Log Samples for a) BH-9, and b) BH-12.............. 59

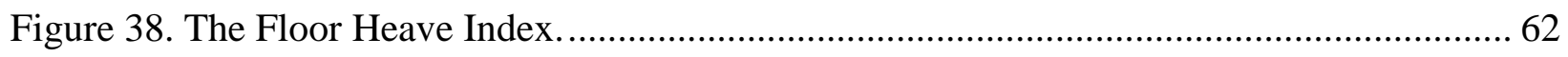

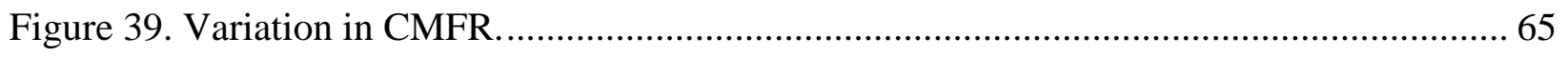

Figure 40. LaModel mesh for overburden stress in Mine A (adopted from Cicek et al., 2020)... 68

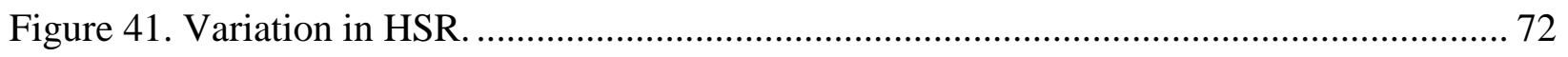

Figure 42. Floor Heave Index applying modified CMFR system. ........................................ 74 


\section{List of Tables}

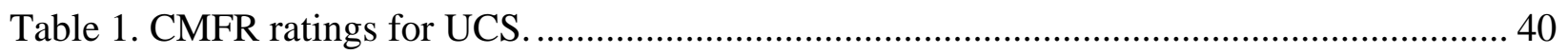

Table 2. CMFR rating for discontinuity spacing. .......................................................... 41

Table 3. Calculation procedure of unit rating and CMFR. .................................................. 42

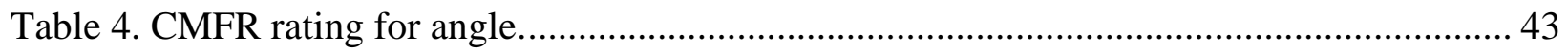

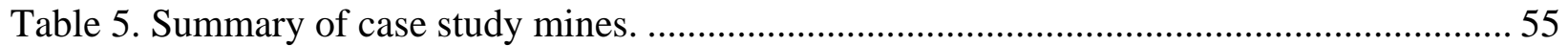

Table 6. Horizontal Stress Rating calculation............................................................... 60

Table 7. Unit Rating examples for floor layers with UCS greater than $40 \mathrm{MPa}$........................63

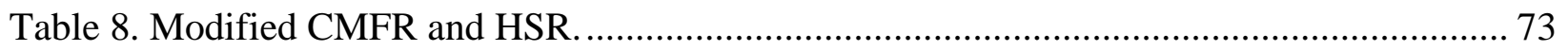




\section{Chapter 1 Introduction}

\subsection{General Overview}

In 2020, 706.4 million tons of coal was produced in the U.S. and approximately $38 \%$ of the total coal production was provided by means of underground mining methods (MSHA, 2020). Ground control related fatalities and injuries in the U.S. underground mining industry have significantly decreased; however, it is still one of the leading causes for major hazards in underground coal mines. According to MSHA, ground fall related accidents accounted for $28.2 \%$ of the occupational fatalities in underground mines between 2013 and 2018. Within the same time period, 1,082 out of 9,249 nonfatal lost-time injuries were caused by ground fall accidents (MSHA, 2019).

Coal mine ground control design tools developed by National Institute for Occupational Safety and Health (NIOSH) have been reliable methods for coal mine design and ground control plans. In the early 1990s, Mark (1990) proposed a chain pillar design software, the Analysis of Longwall Pillar Stability (ALPS); this design method has been one of the most accepted and successful gateroad pillar design methods in the U.S. underground coal mining sector. Success of the ALPS

program in the U.S. led to the development of the Analysis of Retreat Mining Pillar Stability (ARMPS) program (Mark and Chase, 1997), its upgraded version ARMPS2010 (Mark, 2010), the Analysis of Roof Bolt Systems (ARBS) (Mark et al., 2001), and the Analysis of Multiple-seam Stability (AMSS) (Mark et al., 2007). It also led to the development of the Analysis of Longwall Tailgate Serviceability (ALTS) (Colwell et al., 1999) and its updated version ALTS II (Colwell et al., 2003) in Australia. Moreover, Mark and Agioutantis (2018) recently developed Analysis of Coal Pillar Stability (ACPS) which combines ALPS, ARM, and AMSS along with the latest research findings into a single pillar design software. At present, the above-mentioned approaches are used by the U.S. and Australian underground coal mining industries to design roof, pillar, and rib stability control. Their success and acceptance in the coal mining industry signify that these approaches should be extended to floor stability design.

Floor heave is noted by Rockaway and Stephenson (1979) as "the process which occurs when the stress applied to the floor material (lithologically termed underclay) exceeds the bearing capacity of the floor strata.” Gadde (2009) defines the floor heave in underground coal mines as the 
manifestation of the large plastic movements mobilized in mine entries, due to the excess increase in moisture content, mining induced stresses, or both upon reaching the limit state of floor strata. In addition to the high stress concentration in the immediate floor, the presence of weak strata usually constitutes floor heave problems. The weak floor material underlying the coal seam is generally termed as claystone by drill technicians, underclay by geologists, and fireclay by miners (Gadde, 2009).

In practice, minor floor heave is treated by scaling the deformed floor. This type of minor floor heave problem does not possess an immediate threat to mining. However, a significant amount of floor heave poses a considerable risk for sustainable and safe mining of coal resources. Though there has not been a quantitative classification accepted by the experts to identify minor or major floor heave magnitude, Zhang et al. (2011) quantified minor floor heave as ranging from $100 \mathrm{~mm}$ (3.9 inches) to $200 \mathrm{~mm}$ (7.9 inches) with a rate less than $0.5 \mathrm{~mm} /$ day (0.02 inches/day).

Gadde (2009) states that a suitable floor heave analysis technique should be selected distinguishably for short-term and long-term stability problems; here, any problem that occurs during the service lifespan of opening would be considered a short-term problem, and any problem that emerges after mining has ceased would be considered a long-term problem. In the short-term, the extensive amount of floor heave causes narrowing of the mine entries and might lead to the closure of entries and abandonment of a whole section or panel of mine (Gadde, 2009). The unplanned closure of mine entries disrupts the production and ventilation, increasing the difficulty for personnel to travel escapeways along with trip hazards (Klemetti et al., 2020). Furthermore, continuous excessive floor heave can cause changes in the stress state of the entry roof and rib and may trigger roof or rib failures. In the long-term, the punching of pillars into the weak mine floor over the older workings causes surface subsidence, which may result in damage of surface structures such as highways, farmlands, and buildings (Sizer and Gill, 2000). Further, the pillar punching results in subsidence may cause implications in multiple seam mining in the form of elevated abutment stresses (Sears, 2020). Gadde (2009) indicated that surface subsidence due to time dependent floor heave is a major problem in the Illinois basin. He also noted that the mine seals can be damaged in the long-term as a result of extensive floor deformations (Gadde, 2009). 
Numerical and empirical methods (Mark and Bieniawski, 1986; Colwell et al., 1999; Hasenfus and Su, 1992; Cassie et al., 1999) have been commonly employed for pillar and roof stability analysis. In order to integrate more simple and practical procedures into the preliminary stability assessments, engineering classification systems based on analysis of case histories are postulated as an essential adjunct to estimate large scale rock mass behavior in engineering works (Coates, 1964; Coates and Parsons, 1966; Deere and Miller, 1966; Underwood, 1967; John, 1962; Onodera, 1970; Iida et al., 1970; Franklin et al., 1971). However, literature review has shown that the application of empirical formulation and rock mass classification systems on floor stability analysis have been limited.

More specific to the underground coal mining applications of rock mass classification systems, the Coal Mine Roof Rating (CMRR) was established for U.S. coal mines (Molinda and Mark, 1993; Mark and Molinda, 2005) and is widely accepted both in the U.S. and around the world. A few examples of rock mass classification systems which focus on the floor are available. Buddery et al. (1992) derived a classification system for the roof and floor of coal mines in South Africa; similarly, a Floor Stability Rating (FSR) was developed for the mines in South Africa to determine problematic weak floor conditions (Latilla, 2004). However, none of these floor classification techniques are accepted by the industry or even widely known.

Riefenberg (1995) stated that CMRR can be applicable to assess the floor with necessary modification. In light of this study, the most recent classification system for floor, namely the Coal Mine Floor Rating (CMFR), is proposed for Australian coal fields by Mo (2019). The CMFR classification system was developed as a practical method to assess the potential behavior of floor strata in Australian coal mines (Mo, 2019). This empirical rating system quantitatively describes the complex nature of floor rock mass. In order to assess the stability of the floor, Mo (2019) also created the Floor Heave Index (FHI), which is a logistic regression equation that separates failure and non-failure cases. As the rock mass classification systems are derived based on case histories, they are usually locally applicable within the extent of the database. Although it is fairly possible to extrapolate the applications of rock mass classification for the cases which are not included in the database, sharing similar geologic settings and operational features is required. 


\subsection{Problem Statement}

Despite the major progress in reducing floor heave incidents in the Illinois coal basin of the U.S. underground mining sector, Sears et al. (2018) stated that floor heave is an increasing problem in the deep underground coal mines of other U.S. coal mining regions. Past and recent research has suggested that floor stability research in the U.S. has focused on the Illinois Basin, consisting of coal deposits from the larger part of Illinois and parts of Western Indiana and Western Kentucky. Nondurable weak materials associated with underclay, claystone, and clayey shale are found over the large extent of the Illinois Basin (Odom and Parham, 1968). Presence of weak immediate floor material over the Illinois Basin caused many floor heaves in bearing capacity failure mode and subsequent catastrophic surface subsidence over many decades (Gadde, 2009). However, very little attention is being paid to floor heave mechanisms other than the bearing capacity failure.

Therefore, it is believed that different floor stability analysis techniques should be conducted based on the mechanism of the failure, which is discussed in detail at a later point in this thesis. Deficiency in floor stability analysis which concentrates on mechanisms other than bearing capacity and applicable in other parts of the U.S. is recognized. Although the Illinois Basin has received a vast amount of attention and has been investigated by a number of researchers, the findings and proposed solutions to floor heave can be useful for the bearing capacity failures experienced in the Illinois Basin.

National Institute for Occupational Safety and Health (NIOSH) research for longwall pillar stability (Mark, 1990; Mark, 1992), roof stability (Mark and Chase, 1997; Mark, 2009; Mark, 2010; Esterhuizen et al., 2015), and rib stability (Mohamed et al.,2019; Mohamed et al., 2020; Rashed et al., 2020) showed that the Coal Mine Roof Rating (CMRR) classification system together with load analysis can be successfully used to analyze stability. The recent Coal Mine Floor Rating (CMFR) method used in Australia (Mo, 2019), derived based on the CMRR method in the U.S., was an initial step towards incorporating similar methodology to floor stability design. Although the CMFR method is very similar to the CMRR that has been successfully used in the U.S. coal mining industry, the applicability of the CMFR method in U.S. coal mines has not been verified yet. 
During this work, specific effort has been spent on coal resources in Eastern U.S., and a database was built containing case histories from active mines in Eastern U.S which experience the buckling type of floor failure. This thesis documents the details of the modification of the CMFR classification system based on analysis of failure and non-failure cases in the Eastern U.S. The scope of this study includes analyzing the floor heave based on the floor heave mechanism, and implementing the modified CMFR system to forecast the stability of underground structures in the U.S.

\subsection{Objective of Thesis}

The goal of this research is to implement a rock mass classification system into regular ground control analysis in Eastern U.S. underground coal mines for assessing the potential floor failures. Therefore, it aims to analyze the floor heave case studies from currently active mines in the Eastern U.S. The main objectives of this research are:

(i) To compile a broad database with several actual cases of stable and unstable floors from active underground coal mines from Eastern U.S.

(ii) To examine the applicability of the Coal Mine Floor Rating (CMFR) classification system developed for Australian coal mines to Eastern U.S. coal mines.

(iii) To adapt the CMFR system to Eastern U.S. coal mining industry.

None of the rock mass classification systems have shown promise in accurately estimating the potential floor heave in U.S. coal mines. Any practically applicable innovation which relies on both numerical and statistical methods can contribute to maintaining floor stability in the U.S., which is pursued in this thesis.

\subsection{Statement of Work}

In order to evaluate the applicability of the CMFR system to U.S. coal mines, a database consisting of successful and unsuccessful floor stability cases, i.e. non-failure and failure cases, is built. Data acquisition is performed from different coal fields in the Eastern U.S. During the field trips, the mechanism of floor heave is determined first. Afterwards, site specific mining conditions, geologic core log data, and corresponding core log photographs are collected along with the laboratory test results consisting of Uniaxial Compressive Strength (UCS). Previously published reports and 
papers are used to complete the missing information in the database. After gathering all of the case history information together, the CMFR system is applied to the case histories. Better understanding of the stress distribution around pillars in the vicinity of the floor heave area is gained through boundary element model software LaModel. In light of the results from both the boundary element and sensitivity analysis, modifications are made to the CMFR methodology in order to propose an applicable rock mass classification system capable of predicting potential floor heaves in the U.S.

\subsection{The Organization of the Thesis}

This thesis is organized into seven chapters as described below:

Chapter 1 is the introduction which provides the background, problem statement, objective of thesis, and statement of work.

Chapter 2 provides a global literature survey for floor heave and related rock mass classifications systems; pertinent literature review is available in required chapters.

Chapter 3 presents the compiled database, consisting of background, global, and local geologic settings in floor heave cases from Eastern U.S. coal mines.

Chapter 4 presents the application of the CMFR system to the U.S. database and analysis.

Chapter 5 provides the conclusion, discussion, key findings, and recommendations of the thesis. 


\section{Chapter 2 Literature Review}

\subsection{Introduction}

This chapter explains three principal floor heave mechanisms along with other possible mechanisms. Different mechanisms observed in international and U.S. mines are presented to visualize each mechanism. Later, the application of rock mass classification systems in engineering projects, mining and tunneling projects, and floor stability analysis is explained. The two rock mass classification systems developed for coal mines, the Coal Mine Roof Rating (CMRR) and the Coal Mine Floor Rating (CMFR), are explained thoroughly.

\subsection{Floor Heave Mechanisms}

Research studies to characterize floor heave mechanisms have been performed since the late 1890s (Freer, 1892; Jones, 1897). Continuous efforts had been devoted to understanding floor heave mechanisms by Hall (1909), Young (1917), Nelson (1947), and Jenkins (1955, 1958, 1960). Krishna and Whittaker (1973) proposed that the three floor heave mechanisms are: 1) buckling of floor strata, 2) extrusion of underclay from under a solid coal pillar, and 3) penetration of the floor by steel arch legs. Next, Lu and Jiang (1998) presented four types of floor failure mechanisms as bend folding, shear dislocating, water swelling, and squeeze flowing. Shortly after, Whittles (1999) classified the floor deformation on the roadways of UK coal mines into five mechanisms: 1) buckling by horizontal stress, 2) swelling of underclay, 3) deformation along shear planes, 4) flow of underclay, and 5) bearing capacity failure (Figure 1).

In the early 2000s, Nemcik (2003) divided the floor heave mechanism into five major groups:

(i) Puncture of a weak floor below powered supports.

(ii) Buckling of stratified rock floor due to excessive movement of the coal face.

(iii) Compressive floor failure induced by movement of multiple sliding blocks within the floor.

(iv) Floor failure in gateroads that are subject to high lateral stress concentrations.

(v) Floor heave at the tailgate end when mining adjacent to large goaf areas. 


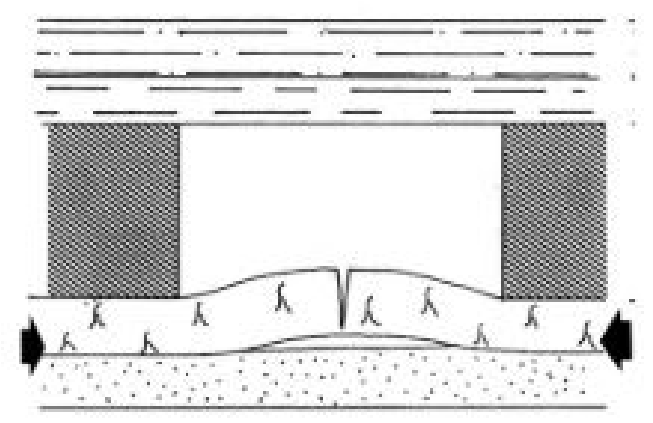

(a)

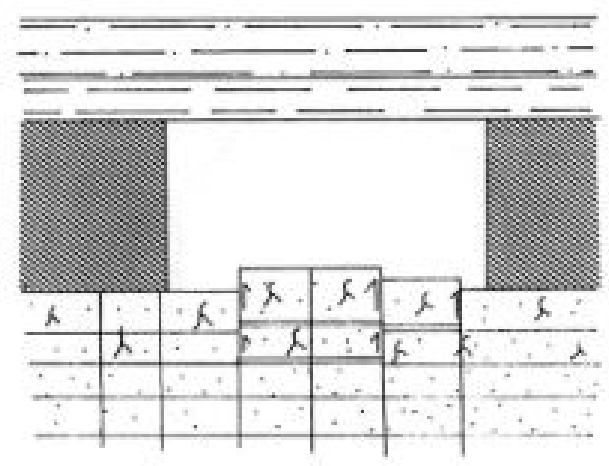

(c)

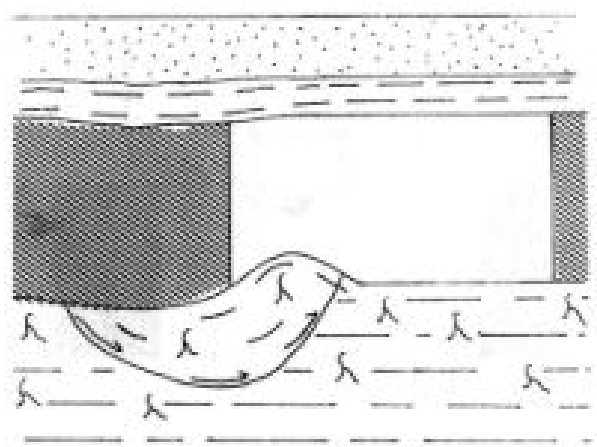

(e)

Figure 1. Floor deformation mechanisms: a) buckling by horizontal stress, b) swelling of underclay, c) deformation along shear planes, d) flow of underclay, and e) bearing capacity failure (adopted from Whittles, 1999).

Although many different mechanisms have been proposed to classify floor heave, most studies have agreed on the most commonly experienced three principal floor heave mechanisms: bearing capacity failure, swelling, and buckling (Aggson, 1978; Bieniawski, 1987; Faria Santos, 1988; 
Vasundhara, 1999; Nemcik, 2003; Gadde, 2009; Mo, 2019). Figure 2 illustrates these three mechanisms of floor heave.

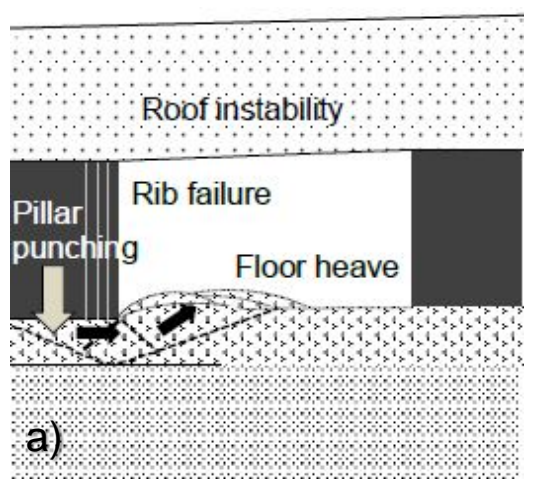

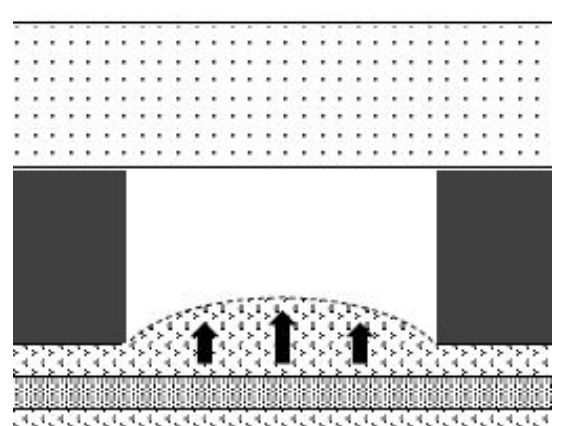

b)

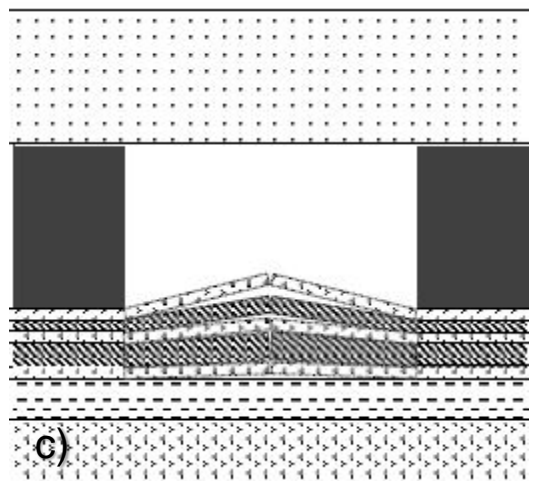

Figure 2. Three principal mechanisms of floor heave: a) Bearing capacity failure, b) Swelling failure, and c) Buckling failure (Mo 2019) (adapted from Whittles et al., 2007).

In the U.S., floor stability research has mainly focused on the Illinois Basin consisting of coal deposits from the larger part of Illinois and parts of Western Indiana and Western Kentucky. The earliest available research on floor heave over weak floors was conducted by Freer (1892). Many exclusive epochal research studies on Illinois Basin floor heave have been conducted (Rockaway and Stephenson, 1979; Speck, 1979; Chugh, 1986(a); Chugh, 1986(b); Marino, 1985; Shankar, 1987; Tandon, 1987; Chandrashekhar, 1990; Jayanti, 1991). Later, Gadde (2009) compiled the largest database for Illinois Basin coal resources and set up quantitative design criteria to prevent or minimize the floor heave related problems in Illinois Basin.

\subsubsection{Bearing Capacity Failure}

Bearing capacity theory is established for civil engineering works and has been extensively used in the foundation engineering branch of civil engineering. Bearing capacity can be defined as the capability of underlying material to support the foundation loads without shear failure. Foundations are designed based on safety factors which rationalize the relationship between the load applied to the foundation and the load bearing capacity of the underlying soil. Also, the safety factor should be determined in a way that foundations should tolerate short-term and long-term settlements and remain stable during initial and consolidation settlements. 
Chandrasekhar et al. (1987) earlier stated that floor stability in coal mines depends on two parameters, which were the ultimate bearing capacity of immediate floor strata and pillar settlement. Consequently, he suggested designing the coal pillars based on settlement characteristics and load bearing capacity of the floor along with coal pillar strength. Later, Seedsman (2012) stated that the weakest component in the integrated roof-pillar-floor structure determines the strength of overall structure, and he recommended invoking the bearing capacity theories of foundation engineering for the cases where floor is the weakest component. The deformation and failure of floor strata under the coal pillar are expected to occur where floor is the weakest component and floor failure may be potentially responsible for other stability issues such as punching of pillar into floor, rib spalling, roof flexures, and subsidence.

Bearing capacity failure occurs where the mining induced stress on the floor exceeds the bearing capacity of floor material. Exceeding the bearing capacity of the floor causes punching of the pillar into the floor. Pillar punching is followed by rupture of floor strata, and floor material under the coal pillar starts moving outward and upward towards the ground surface (Speck, 1981). Upon the failure of the floor under the coal pillar, the load carried by the failed pillar may be transferred to the adjacent pillars. Successive pillar punching and load transfer to the adjacent pillars can cause the progression of floor failure throughout the mine and result in differential settlement if a considerable amount of pillar punching occurs (Speck, 1981). Later, the integrity and serviceability of the roof-pillar-floor system can be lost upon roof falls and associated surface subsidence.

Bearing capacity failure is generally experienced where the weak immediate floor strata overlies a relatively strong stratum. Wuest (1992) stated that the amount of floor heave is controlled by floor lithology, type, and thickness of floor stratum. In the case of bearing capacity failure, increasing thickness of the weak immediate floor promotes excessive floor heave. Floor heave in the presence of a thick weak floor layer may lead to the closure of entries and production delays. Gadde (2009) carried out an extensive study on floor stability analysis of the Illinois basin underground coal mines, which generally have weak immediate floors composed of soft fireclay and claystone. He found that the weak floor of the eastern and western shelves of the Illinois basin have different engineering characteristics from each other. Having considered the noteworthy variation of floor nature between shelves, he developed the two-shelf approach which suggests different equations for the eastern and western shelves for floor stability analysis. 
In addition to the geological configuration of immediate floor, the existence of floor rock with high moisture content also affects the floor stability of coal mines. Chugh and Missavage (1981) and Sainsbury (2003) stated that existence of moisture sensitive rock contributes to bearing capacity failure of floor and gradual pillar settlements in the long-term. The progression of floor failure causes roof integrity loss, rib and pillar failure, and ultimately surface subsidence. The cases where moisture sensitive rocks such as shale appear are studied by Van Eeckhout and Peng (1975), Van Eeckhout (1976), and Singh and Cummings (1983).

Since bearing capacity failure is a commonly observed floor heave mechanism in coal mines, increasing attention has been drawn towards the bearing capacity failure mechanisms. Modes of shear failure of surface structures under weak floor are classified into three groups based on their compressibility characteristics: punch shear failure, local shear failure, and general shear failure (Vesic, 1973; Galvin, 2016). The compressibility characteristics of soil can signify the likelihood of the mode of shear failure. For instance, general shear failure is expected in the presence of densely packed and fine-grained clays, whereas punching shear failure is anticipated where soil is coarse grained and loosely packed. Galvin (2016) stated that general shear failure is considered to be the most common shear failure mechanism. Gadde (2009) states the punching mode of shear failure does not cause significant movement of floor material towards entries; therefore, it may be illustrated as the mechanism which possesses the least risk for short-term floor stability. Gadde (2009) also indicated that general shear failure causes the most significant problems in coal mine floor stability.

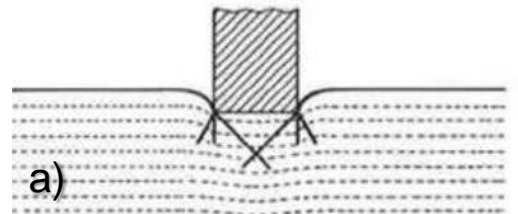

a)
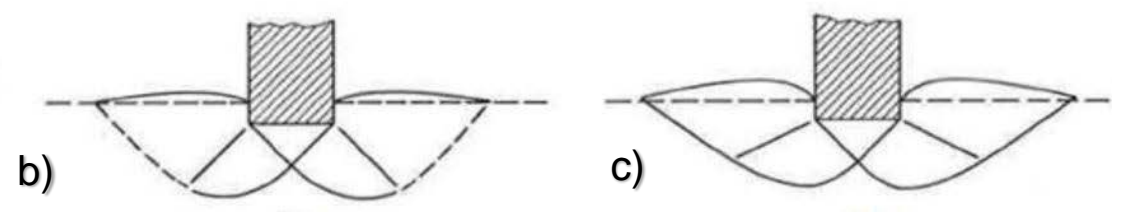

Figure 3. Three modes of shear failure: a) punching shear failure, b) local shear failure, and c) general shear failure (adopted from Vesic, 1973).

Various ultimate bearing capacity formulae have been proposed and used in underground coal mining over many decades. One of the earlier attempts was made by Mandel and Salencon (1969) to estimate the bearing capacity of a weak deformable floor layer which is overlaid by an infinitely 
strong rigid layer. Meanwhile, Brown and Meyerhof (1969) and later Vesic (1973) developed a model for foundations on cohesive two-layer where both layers are undrained, i.e. angle of internal friction $(\phi)$ equals to 0 . Similarly, a model for foundations on cohesionless two-layer where the angle of internal friction is different than 0 is introduced (Meyerhof, 1974; Herdy and Townsend, 1982; Hanna, 1982).

Figure 4 shows the major floor bearing capacity failure that occurred in the Zeigler coal mines in the Illinois Basin (Rockaway and Stephenson, 1979). The depth of cover was recorded between $45 \mathrm{~m}$ (147.6 ft) and $75 \mathrm{~m}$ (246.1 ft). The mechanism of floor failure was attributed as bearing capacity failure due to underclay immediate floor strata. The mining height varies between $1.8 \mathrm{~m}$

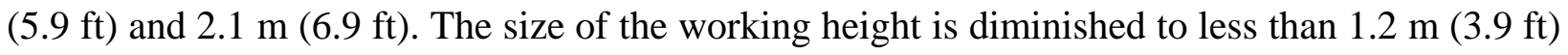
in the locations which experienced severe floor heave.

The Marson coal mine in Helvetia, West Virginia extracted the Sewell seam, which had an approximate thickness of $1.2 \mathrm{~m}(4 \mathrm{ft})$ at the depth of cover ranging from $105 \mathrm{~m}$ (344.5 ft) to 180 m (590.6 ft). The uniaxial compressive strength was 53.8 MPa (7,800 psi) for immediate shale roof and $9 \mathrm{MPa}(1,300 \mathrm{psi})$ for the immediate massive soft mudstone floor. Bearing capacity failure is indicated in the floor strata due to plastic flow of the floor material. Upon failure of the weak floor, relatively strong pillars punched into the floor and the immediate roof deflected (Peng, 1994).

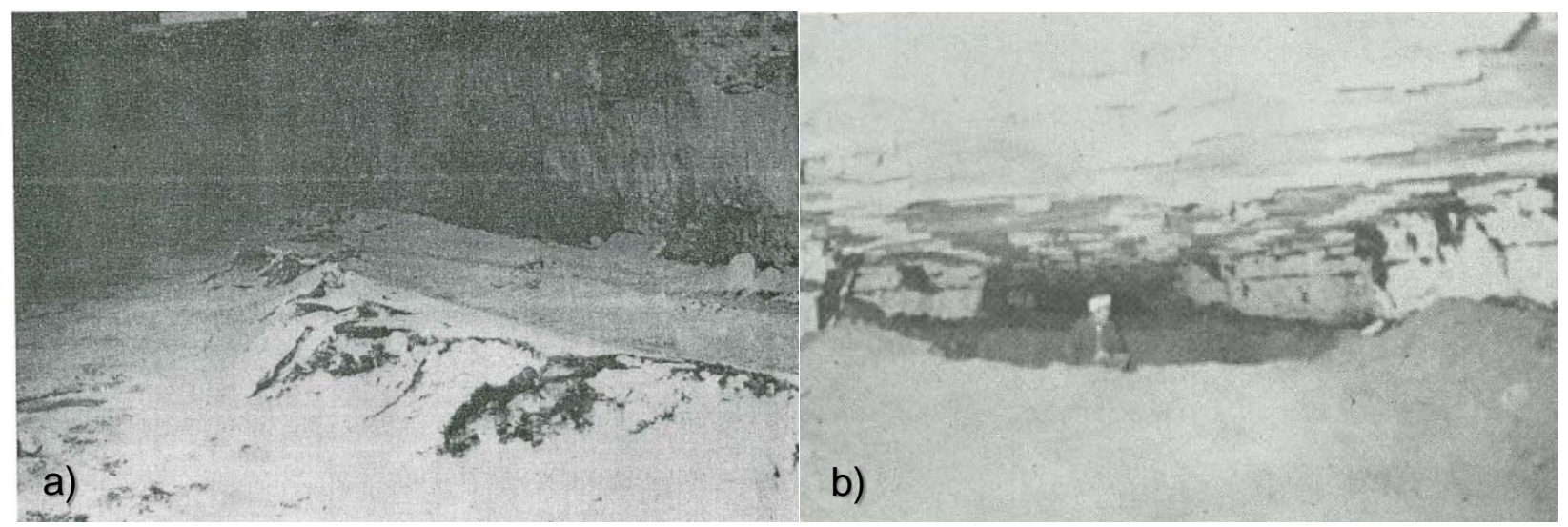

Figure 4. Zeigler coal mine in the Illinois Basin: a) Initial floor deformation (Speck, 1979), and b) Extensive floor heave in No. 5 mine (Speck, 1981). 
A more recent floor heave was observed in a West Kentucky mine in No. 11 seam (Perry et al., 2015). The mining height was $2 \mathrm{~m}$ (6.5 ft), and floor heave was observed where there was an increase in immediate fireclay floor thickness up to about $1.5 \mathrm{~m}$ (5 ft) from a typical thickness of

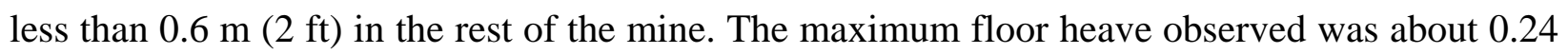
$\mathrm{m}(0.8 \mathrm{ft})$. During floor heave and further punching of pillar into the floor, Perry et al. (2015) observed that the firm roof consisting of strong limestone strata overlying the $0.6 \mathrm{~m}(2 \mathrm{ft})$ immediate black shale roof had bent instead of breaking. This led to high stress concentration on pillars and eventually caused rib failures and entry closures. This failure case illustrates how the punching of pillars due to bearing capacity failure affects the overall roof-pillar-floor structure stability and causes unmanageable consequences, such as the closure of various parts of the mine. Floor heave associated with weak immediate floor strata has also been a significant problem in Australian coalfields. Munmorah Colliery in Newcastle Coalfield experienced pillar failure, surface subsidence, and a considerable amount of floor heave due to the existence of weak floor strata composed of claystone and mudstone (Figure 6) (Vasundhara, 1999).

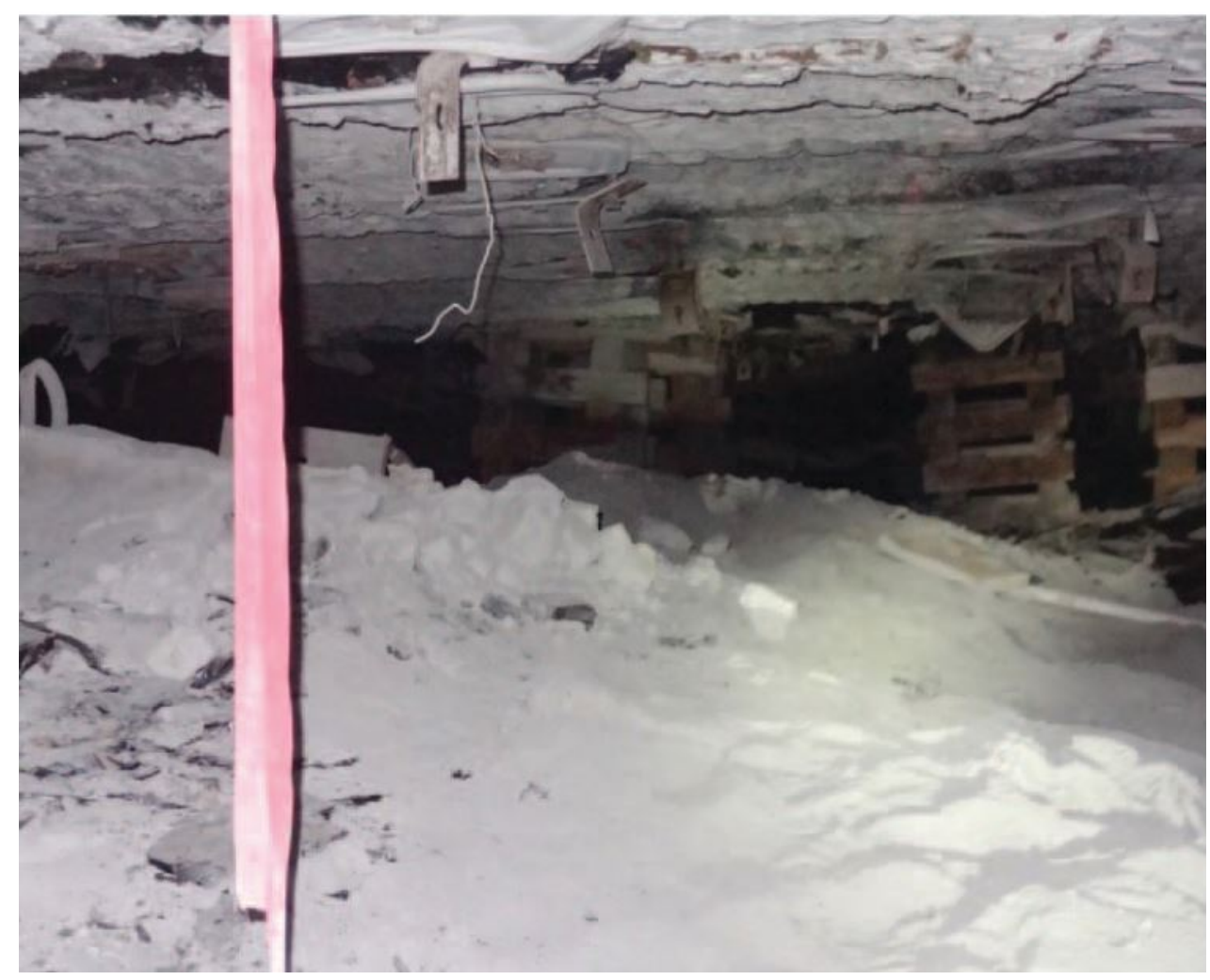

Figure 5. Localized floor heave area in No. 11 West Kentucky seam (Perry et al., 2015). 


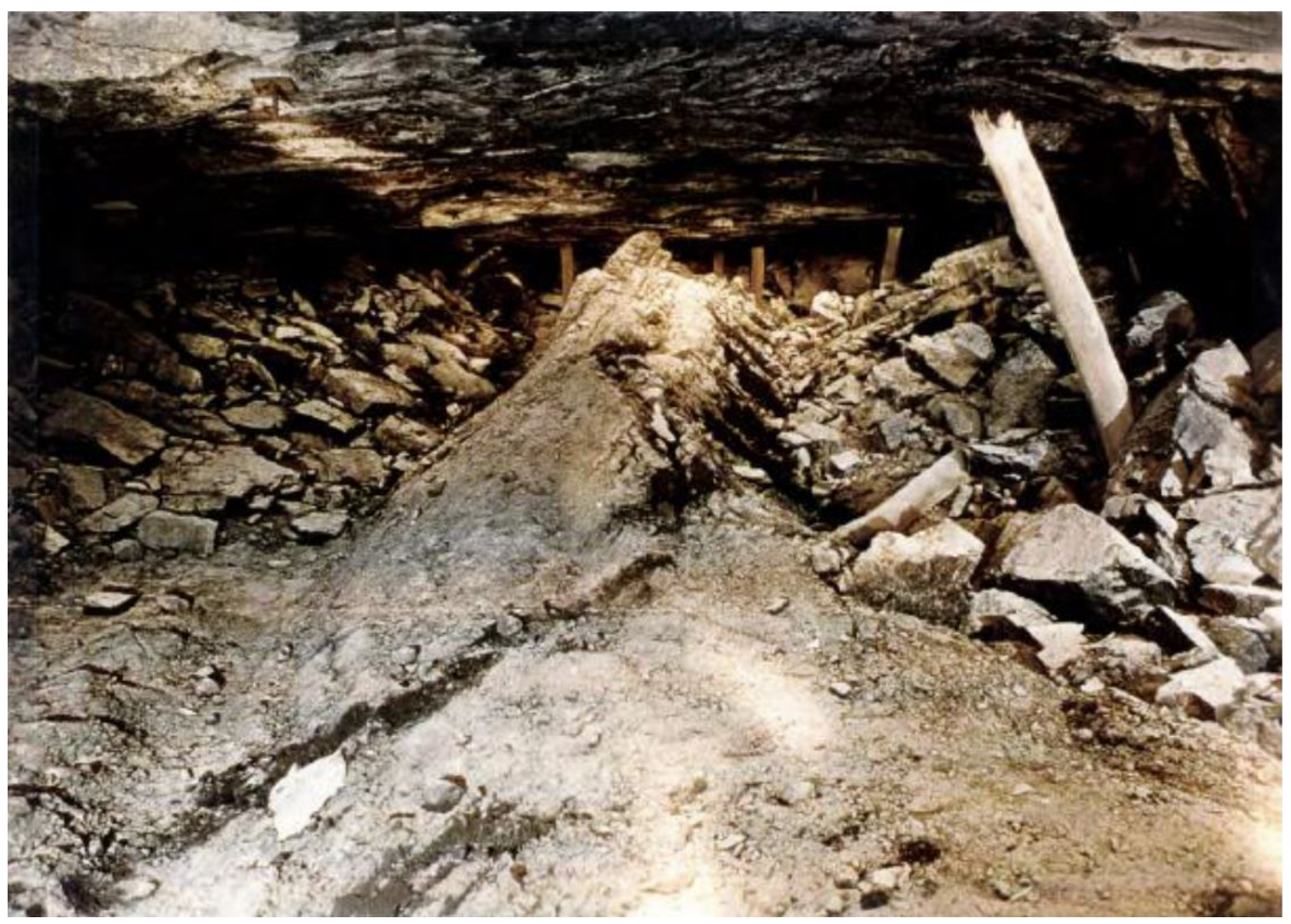

Figure 6. Floor heave at Munmorah Colliery in Newcastle, Australia (Vasundhara,1999).

\subsubsection{Swelling}

Swelling can be defined as volumetric expansion of floor material due to the interaction between moisture or aqueous solutions and floor material, which usually happens without yielding. The interaction between water and floor rocks consisting of clay causes a dramatic decrease in the mechanical properties of the material. Thereafter, decreased mechanical properties result in swelling, which endangers the functionality of mine entries.

However, there has not been a systematic explanation of complex swelling behavior in rocks and soils, but it is known that various factors such as composition and fabric of rock, chemical features of rock and fluid, degree of water exposure, and stress applied to the rocks play a role in swelling failure mechanism. Swelling is usually observed in clay rich rock in a time-dependent manner. Taylor and Spears (1970), Spears and Taylor (1972), and Taylor (1988) investigated how the humidity of mine atmosphere and leakage of water through roof and floor strata causes chemical 
reactions between water and the immediate roof and floor rocks. Thereafter, this results in swelling, diminution in bearing capacity, and deterioration of roof and floor rocks in coal mines. Afrouz (1975a, 1975b) investigated how the moisture content of floor material influences the floor stability, such as a $1 \%$ increase in moisture content can increase the potential underclay heave by $0.7 \%$.

Certain types of clay minerals which tend to absorb water into their chemical structure, expand by volume in the presence of water, and shrink in scarce water are called expansive (Coduto et al., 2010). Expansive soils are described as a difficult foundation material upon changes in the moisture content (Kalantari, 2012). Smectitic and vermiculite clays can be examples of expansive soils (Sainsbury, 2003). Swelling is highly likely to occur in the presence of water or aqueous solutions if the floor material consists of these certain types of clays exhibiting high swelling and shrinkage characteristics (Galvin et al., 1999, Whiteley et al., 2005). Similarly, Santos and Bieniawski (1989) also stated that swelling occurs due to exposure of floor material which is rich in clay, such as fireclays, mudstone, claystone, and shale, to moisture. Claystone, the weak floor material underlying the coal seam, has a diverse range of characteristics from being rock-like material to clay-like material which resembles soft clay (Nemcik, 2003).

Exposure to moisture also affects the stress state of rock material through wetting and drying cycles and gradual swelling. Mills and Edwards (1997) stated that stress tests of claystone are exceedingly dependent on the moisture content, as shown in Figure 7. Likewise, Grim (1968) found that uniaxial compressive strength of a specific type of highly expansive clay consisting of sodium montmorillonite can drop up to one tenth of the dry state uniaxial compressive stress when exposed to moisture. Later, Wuest (1992) stated that uniaxial compressive strength of fireclay can be up to 34.5 $\mathrm{MPa}(5,000 \mathrm{psi})$ in dry conditions and down to $13.8 \mathrm{MPa}$ (2,000 psi) in wet conditions. In three mine sites in England, 35\% to 70\% reduction in floor strength is observed due to exposure of floor material to moisture (Lee, 1961). Chugh and Missavage (1981) stated that rock materials with high moisture content are typically weak and have more potential to lose their strength when exposed to consecutive wetting and drying processes. Further effects of moisture content on rock strength is well documented (Hawkins and McConnell, 1992; West, 1994; Wakim et al., 2005; Barefield and Shakoor, 2006; Vásárhelyi and Ván, 2006; Shakoor and Barefield, 2009; Yilmaz, 2010). 


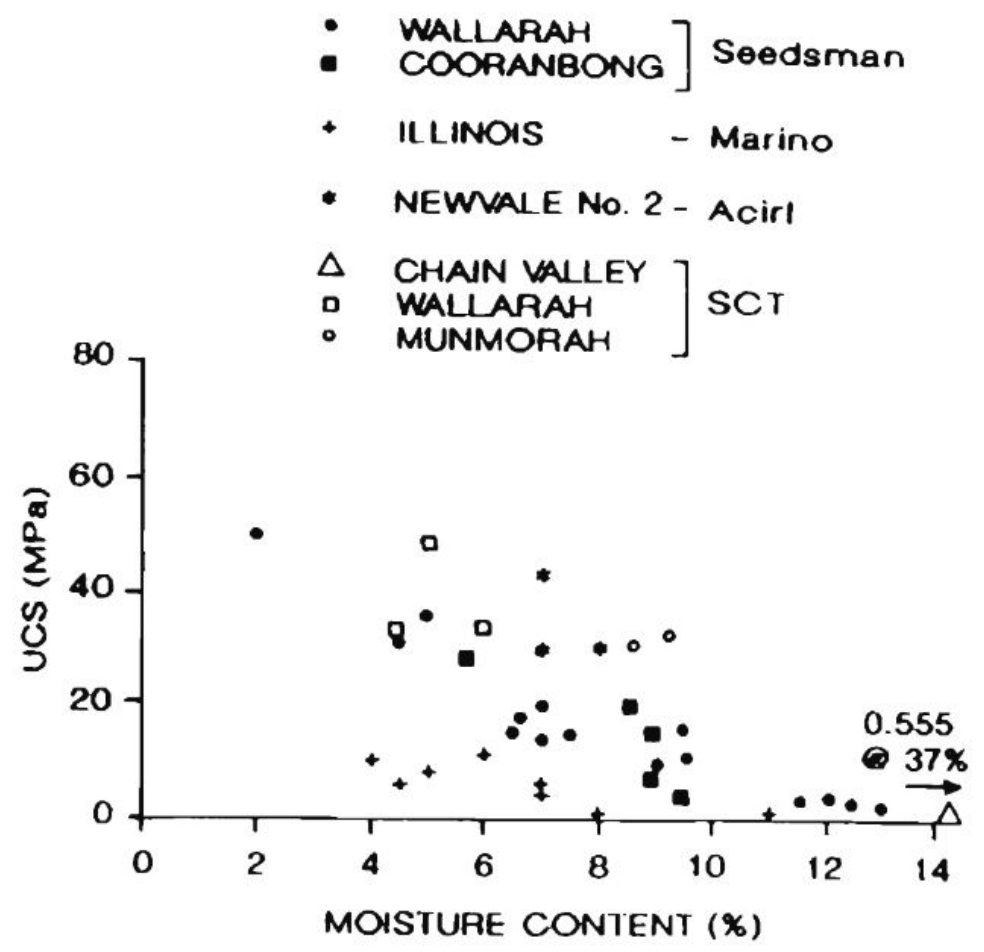

Figure 7. Claystone UCS variation with moisture content (Mills and Edwards, 1997).

For some swelling cases, understanding the state of stress is as important as the mechanical properties of immediate floor material. Fredlund (1996) highlighted the importance of relating the swelling behavior to changes in stress state, such as between in situ stress and final stress. Also, if the ground control plan does not account for short-term and long-term material properties of the immediate floor, gradual swelling over a few years may occur in the presence of excess water. For instance, Gadde (2009) reported a gradual floor swelling case in the Illinois Basin where excess water existed on the floor (Figure 8). The entries converged gradually and entry closure exceeded

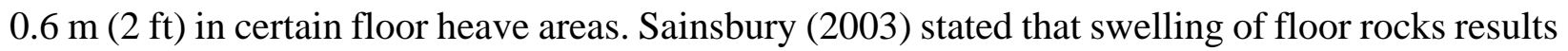
in floor heave and can further over-pressurize the support systems. Einstein (1989) and Wakim et al. (2005) investigated how pressure applied by swelling reaches several times the stress applied by rock load itself and causes rupture and collapse of shotcrete and bolts. 


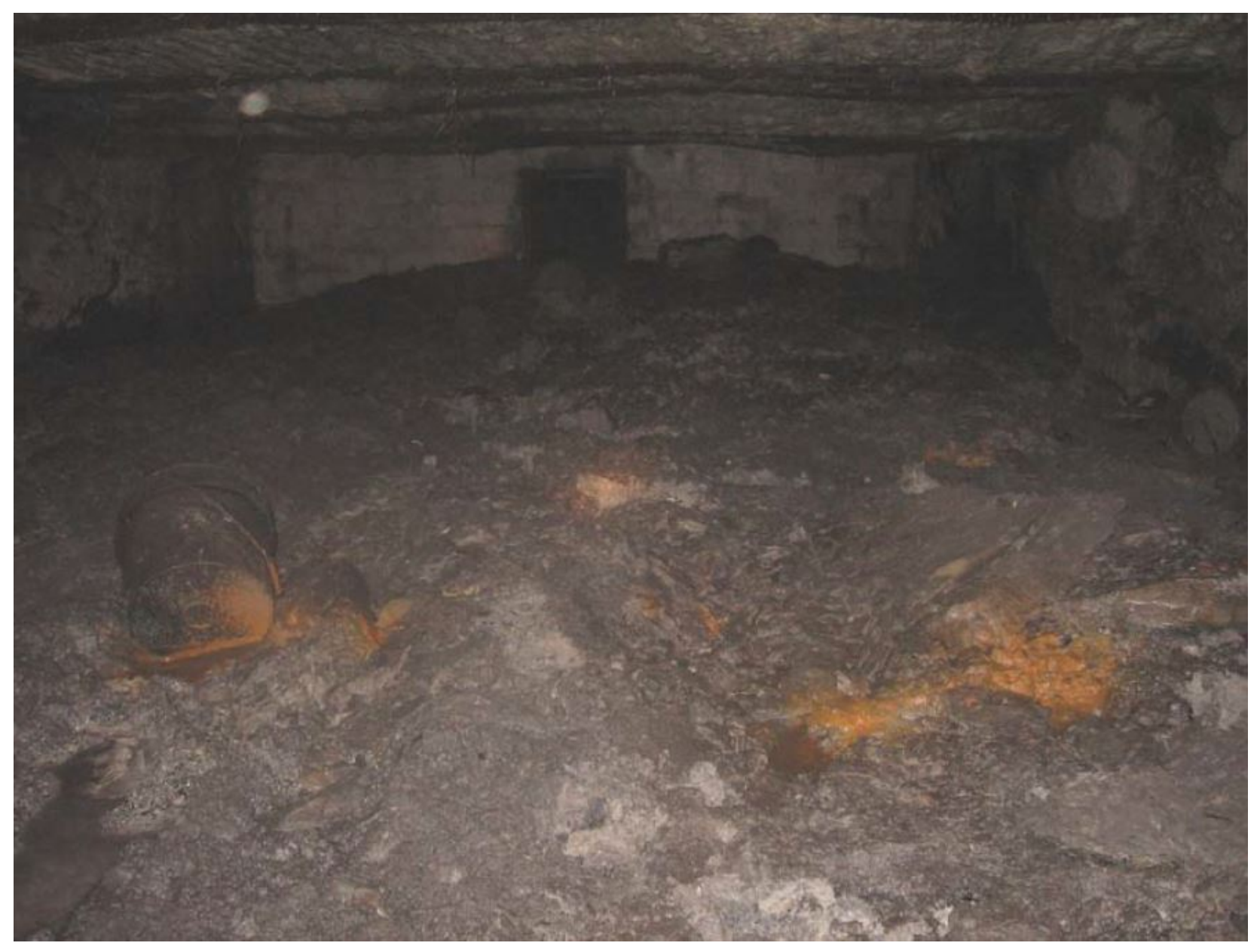

Figure 8. Partially closed entry due to gradual swelling (Gadde, 2009)

Although exposure to water or moisture contributes to all types of floor heave mechanisms, the role of water in swelling mechanisms is indispensable in terms of causing the degradation of material over time. At Cooranbong in Newcastle Coalfield, a combination of swelling and buckling was observed (Figure 9, Figure 10). In this particular case, buckling was driven by swelling of the immediate floor strata rather than high horizontal stress, i.e. the immediate floor buckled as a result of the swelling behavior of floor rocks. Whiteley et al. (2005) states that swelling occurred in the flooded roadways after 15 years of mining at Cooranbong. It is recognized that swelling happened in the roadways, but the floor underneath the pillar remained stable (Figure 11). The reason for a stable immediate floor underneath the pillar is hypothesized to be the confinement stress originated by the vertical load on the pillar (Mo, 2019). 


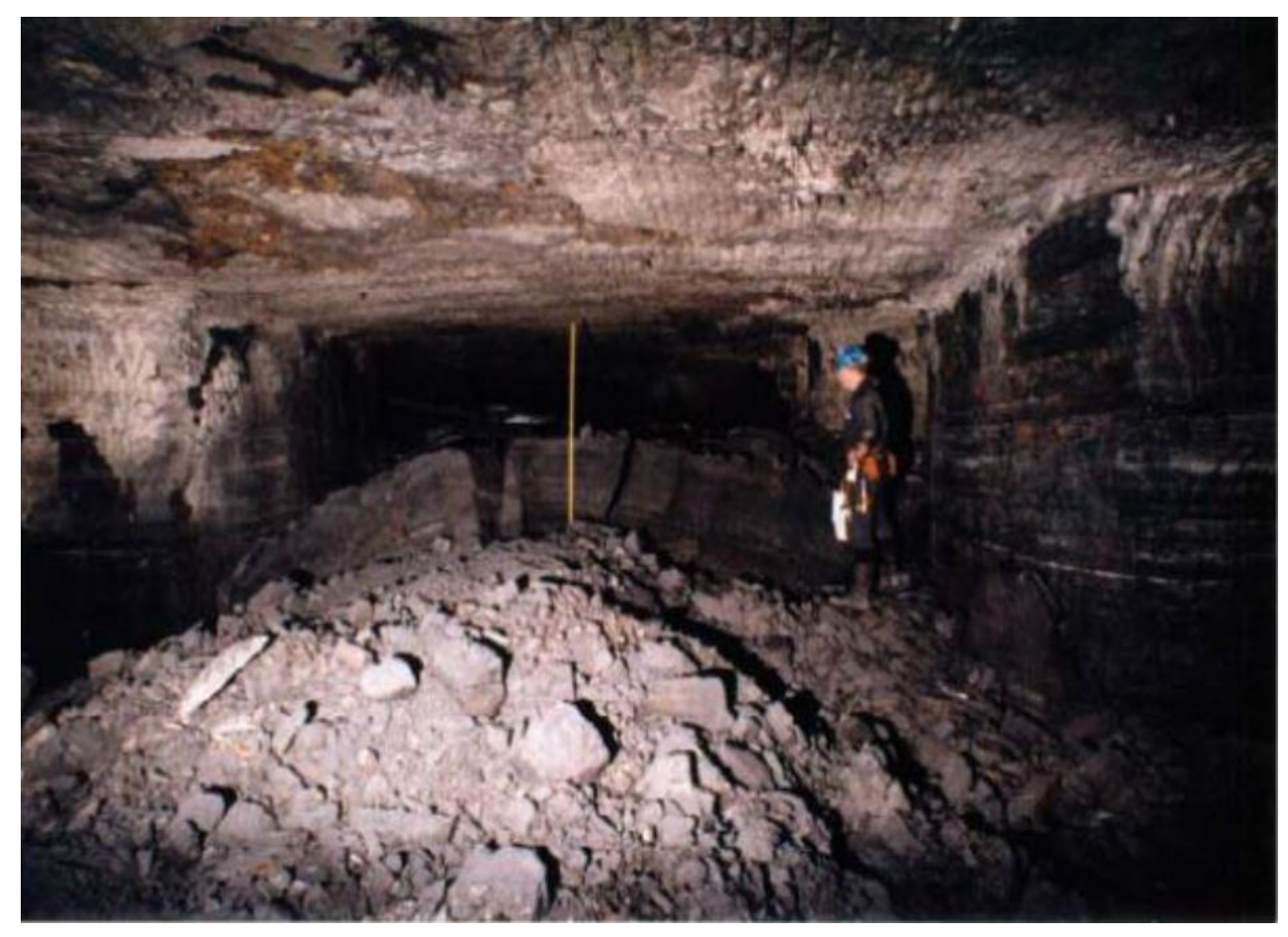

Figure 9. Floor heave due to combination of swelling and buckling heave at Cooranbong in Newcastle Coalfield (Galvin et al., 1999).

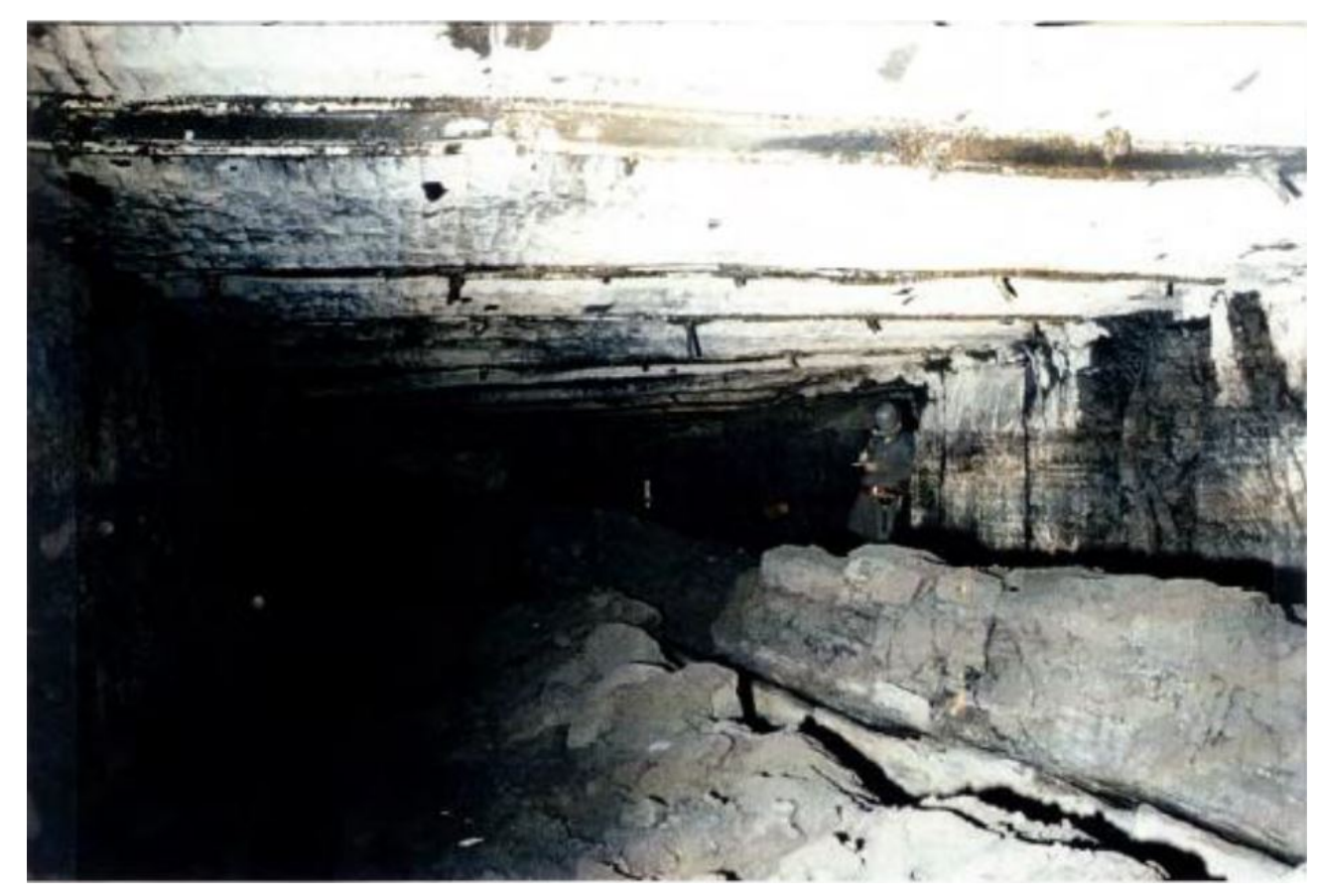

Figure 10. Buckling of floor strata due to swelling at Cooranbong in Newcastle Coalfield (Vasundhara, 1999). 


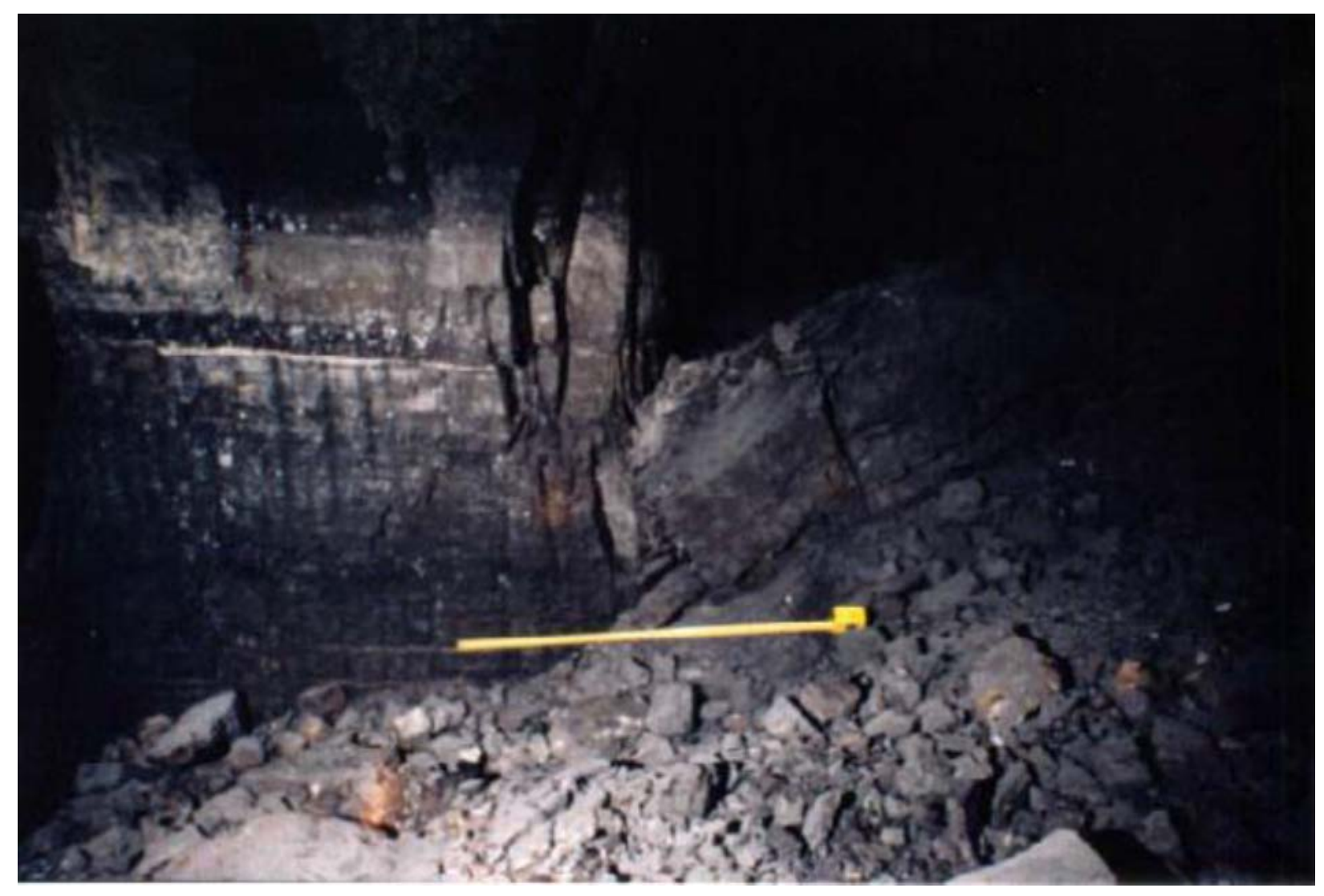

Figure 11. Stable pillar next to floor heave area in Cooranbong (Galvin et al., 1999).

Another swelling case was reported at the Lublin coal basin in Poland, where a weak and moisture sensitive floor material had substantial influence on the stability of the floor (Kwasniewski, 1990). A trona mine in Turkey experienced floor heave due to swelling behavior of the immediate floor rock (Saydam et al., 2003; Onargan et al., 2004; Onargan et al., 2012). Fujii et al. (2011) analyzed floor heave at the Kushiro coal mine under the Pacific Ocean in Japan. The coal mine extracts Eocene coal seam and had about 95 abandoned roadways which were about 50 years old. The depth of cover was $300 \mathrm{~m}$ (984.3 ft) and the height of old roadways was about $2.5 \mathrm{~m}(8.2 \mathrm{ft})$. As represented in Figure 12, the majority of the abandoned roadways were closed due to floor heave and roof deflection. The reason for the floor heave was considered to be the exposure of clastic rocks, containing smectic, to a water source which caused a significant amount of deformation in the roof and floor strata. 


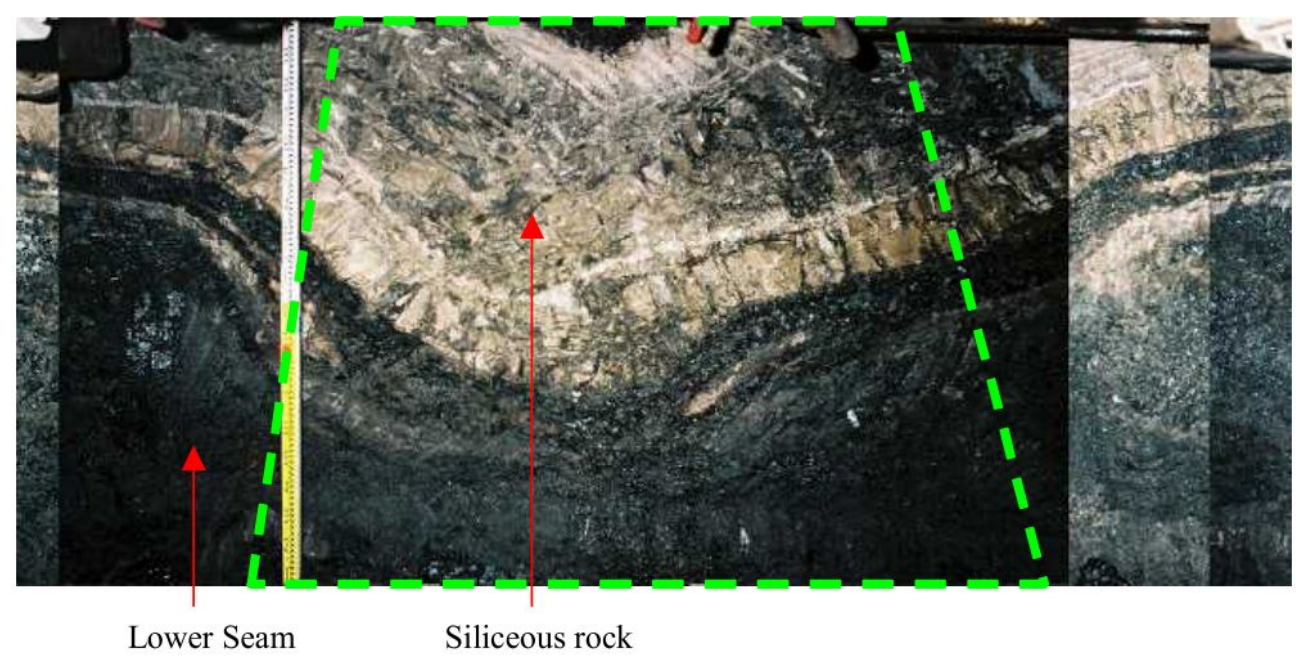

Figure 12. Closed roadways in Kushiro coal mine in Japan due to significant plastic deformation of siliceous rock and clay (Fujii et al., 2011).

\subsubsection{Buckling}

The buckling type of floor failure typically occurs when the immediate floor layer is stronger than underlying strata and is subjected to high horizontal stress (Aggson, 1978; Faria Santos and Bieniawski, 1989; Peng et al., 1995).

Figure 13 illustrates stages of buckling (Peng, 1994; Peng et al.,1995). If the vertical and horizontal stresses are not high during the development stage, substantial floor heave may not occur. However, the total horizontal stress on the pillars increases as abutment load is applied to the pillar in addition to the development load during retreat mining. An increase in mining-induced vertical stress directly intensifies the shear stress on bedding planes. Shear failure starts to occur, since the shear strength of the bedding planes are low and prone to fail (Figure 13a). Mining-induced vertical stress further mobilizes sliding and separation of bedding planes. The composite floor beam separates into various individual beam members due to the shear failure along the bedding planes. Thus, the immediate floor member no longer behaves like a single beam, but instead behaves like a stack of beams. This behavior results in the change and increase in tensile stress. The increase in the tensile stress applied to each beam causes tensile failure (Figure 13b). The vertical stress is relieved by subsequent shear and tensile failures. However, high horizontal stress accelerates 
further movement and fracturing of floor members. Continual existence of high horizontal stress causes the broken floor members to heave (Figure 13c).
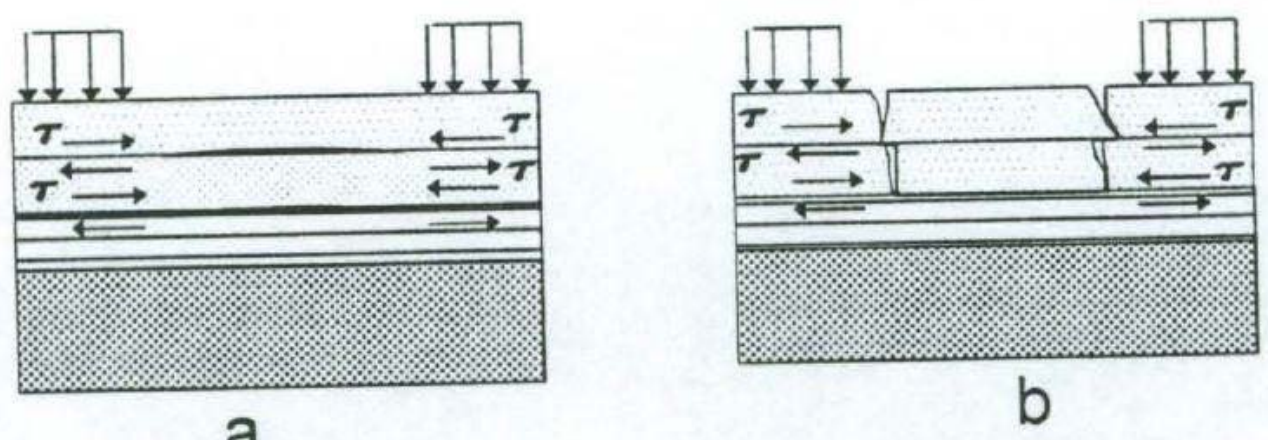

a

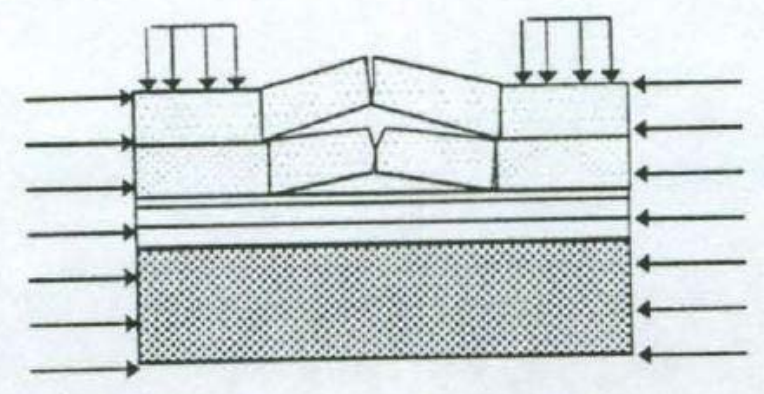

C

Figure 13. Floor heave sequence in Smoot mine, West Virginia (adopted from Peng, 1994).

Existence of high horizontal stress is one of the most important contributing factors to buckling. Aside from horizontal stress, geological characteristics of immediate floor such as type of floor rock, thickness of floor rocks, and existence of geological anomalies can influence the occurrence and intensity of buckling. For instance, the severity of floor heave in the buckling mechanism is governed by the thickness of the strong immediate floor layer, i.e. a thicker immediate layer lowers the likelihood of buckling (Wuest, 1992). The stated correlation between thickness of a strong unit and possibility of floor failure can be attributed to the confinement created by the stronger layer.

Numerous examples of buckling are available in literature. The Beckley coalbed in Glen Rogers mine in Southern West Virginia has experienced the buckling type of floor heave problems 
extensively since the early 1900s (Aggson and Curran, 1978) (Figure 14a and Figure 14b). The Beckley coalbed is extracted at depth of cover ranging from $185 \mathrm{~m}(607 \mathrm{ft})$ to $400 \mathrm{~m}(1,312.3 \mathrm{ft})$. The West Virginia State Department of Mines report indicated that the floor heave in Glen Rogers mine results from biaxial, horizontal, compressive stress conditions, while water and depth of cover do not contribute to floor heave (Keatley, 1929). The principal horizontal stresses are recorded as $12 \mathrm{MPa}(1,740.5 \mathrm{psi})$ and $22 \mathrm{MPa}(3,190.8 \mathrm{psi})$. The major principal horizontal stress is perpendicularly applied to the entries at the floor heave locations. Consequently, Aggson and Curran (1978) identified the explicit correlation between entry orientation and direction of maximum compressive component of horizontal stress. Shortly after, Jeremic (1981) described the correlation between floor failure and lateral tectonic stress for a buckling case in Western Canada. In an Alabama longwall mine, extreme buckling of highly stratified shale overlying the fireclay occurred up to $2.4 \mathrm{~m}(7.9 \mathrm{ft})$ where the floor touched the roof in several of the gate road areas, as shown in Figure 15 (Serata et al., 1984).

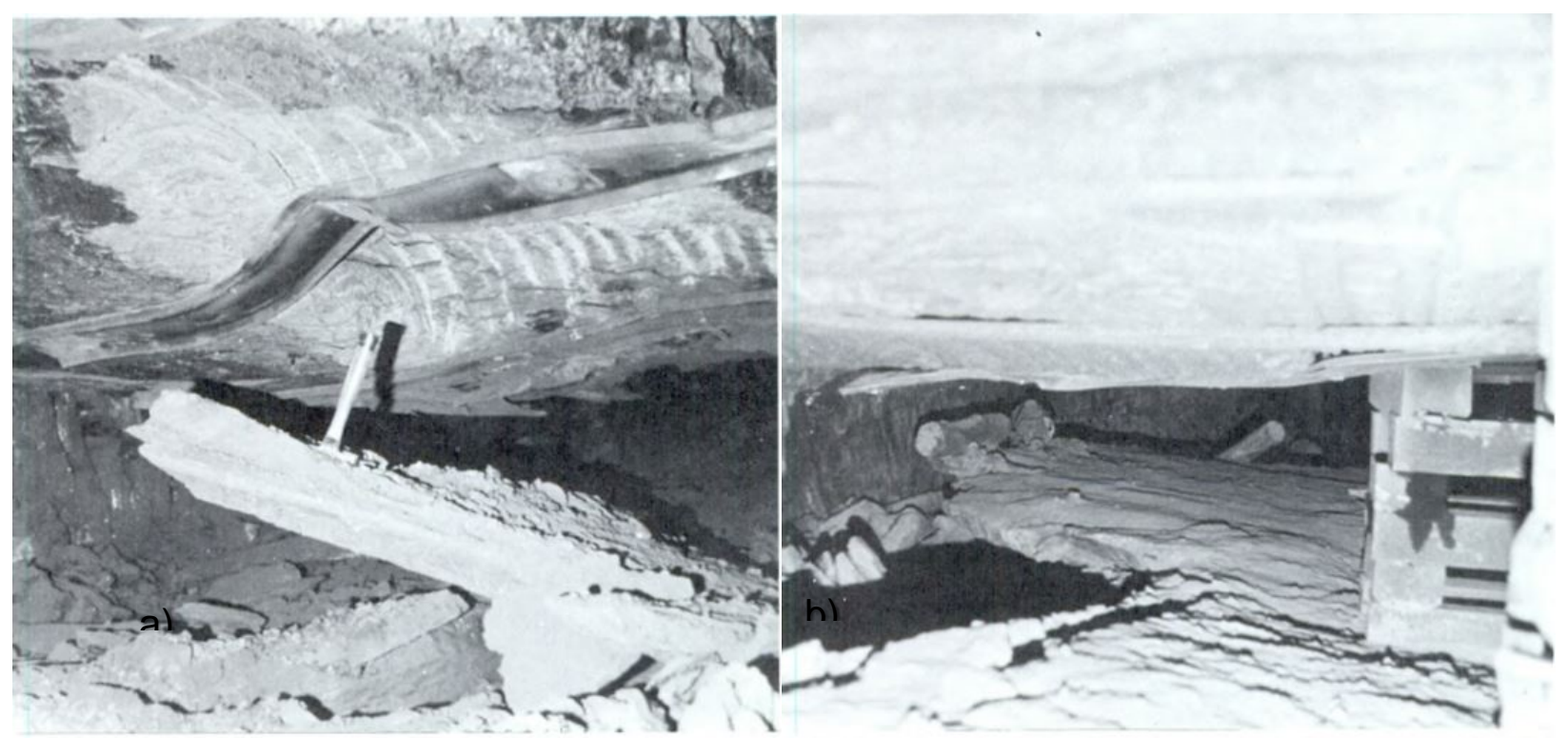

Figure 14. Floor heave in Beckley coalbed: a) buckling of immediate floor into the entry, and b) immediate floor failure near the pillar (Aggson, 1978). 


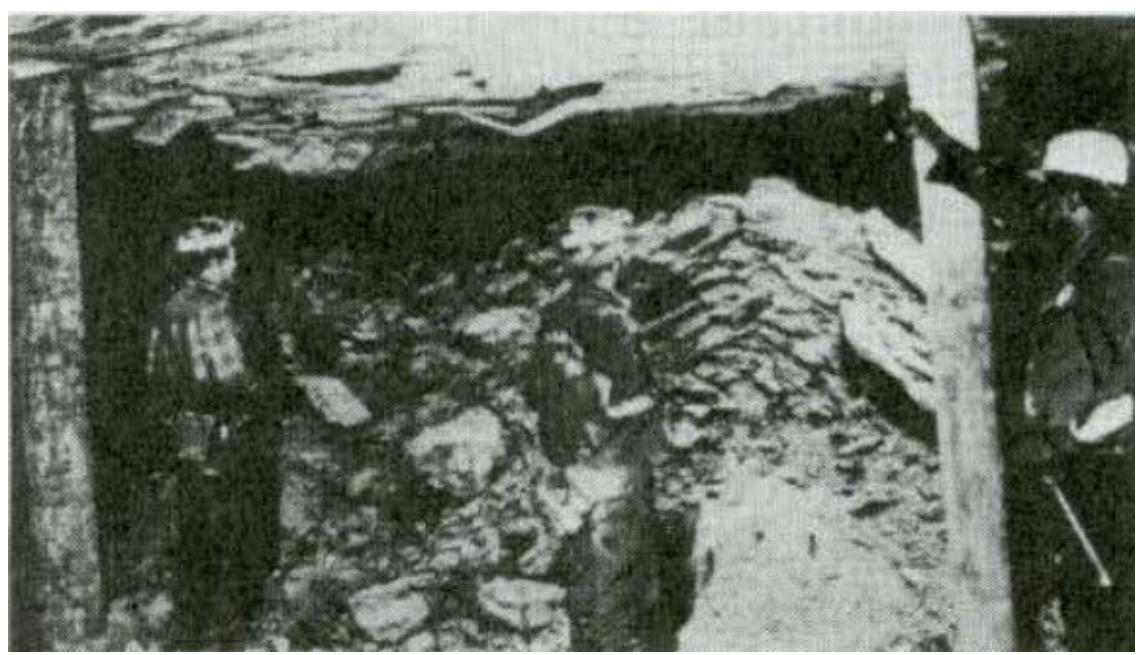

Figure 15. Extreme buckling in an Alabama coal mine to the extent where the floor touched the roof (Serata et al., 1984).

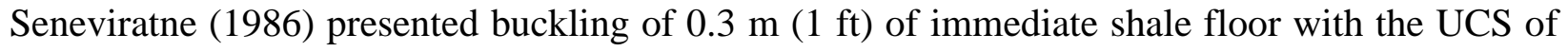
$58 \mathrm{MPa}(8,412.2$ psi) in West Cliff Colliery in the Southern Coalfield of Sydney Basin in New South Wales due to the presence of high horizontal stress with a magnitude of $30 \mathrm{MPa}(4,351.1$ psi). Matetic et al. (1987) represented the floor heave problems with two different mechanisms in the upper and lower seam during multiple-seam mining in Raleigh County, West Virginia. It is reported that hump-like floor heave is experienced where low-modulus shale floor is present, whereas buckling is observed where the floor is high-modulus sandstone (Matetic et al., 1987) (Figure 16).

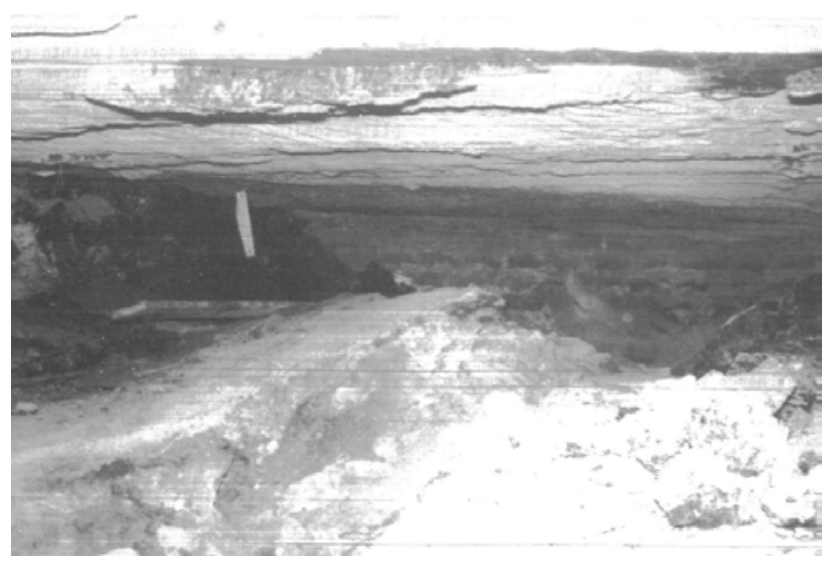

Figure 16. Buckling of high-modulus sandstone floor in a lower mine during multiple-seam mining (Matetic et al., 1987). 
An analogy can be made between the interaction of concrete building slabs with underlying soil medium in structural engineering works and the interaction between an immediate strong layer above a weak layer in underground mining. Many structural engineers have conducted research on beams and plates on elastic foundations (Vlasov and Leont'ev, 1966; Vallabhan and Das, 1987, 1988, 1989). The application of methods from structural engineering for analyzing the buckling type of floor failure has been well accepted in mining literature. For instance, one of the oldest and most well-known methods for modeling the soil-structure interaction, the Winkler elastic foundation method (Winkler, 1864), has been applied to analyze the buckling type of floor heave in Smoot Mine, West Virginia (Peng, 1994; Peng et al., 1995). Peng et al. (1995) and Wang (1996) analyzed the floor heave in Smoot Mine, which exploits the Fire Creek seam with a thickness varying between $1.2 \mathrm{~m}(3.9 \mathrm{ft})$ and $2.1 \mathrm{~m}(6.9 \mathrm{ft})$. The room and pillar mining method is used at a depth of cover varying from $183 \mathrm{~m}$ (600.4 ft) to $270 \mathrm{~m}$ (885.8 ft). The immediate roof consisted of sandstone or sandy shale, and the immediate floor was typically fireclay interbedded with coal streaks. It is reported that floor heave happened upon pillar extraction, the result of weak immediate floor strata where $7.6 \mathrm{~cm}$ (3 inches) of fireclay with the UCS of 39 MPa (5,656.5 psi) was underlain by $0.1 \mathrm{~m}(0.33 \mathrm{ft})$ of strong shale with the UCS of $78 \mathrm{MPa}(1,1312.9 \mathrm{psi})$. As shown in Figure 17, a sudden buckling of the immediate floor in tailgate roadways happened in an Australian coal mine. The reason for the rapid floor failure is attributed to the thinly bedded stiff immediate floor which is attracted by high horizontal stress (Galvin, 2016).

Recently, horizontal stress driven buckling occurred in the Springvale underground coal mine in the western coalfield of New South Wales (Figure 18) (Sheffield and Corbett, 2018). It is noted that the floor heave had been occurring with an increasing magnitude since 2012. With time, the

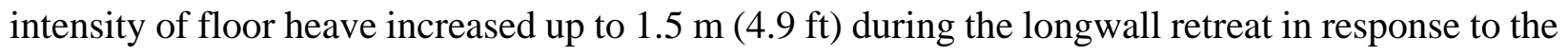
mining induced stresses and an opposite relationship between floor heave magnitude and longwall retreat rate is observed, i.e. high magnitude of floor heave was observed during slow-rate longwall retreat operation. 


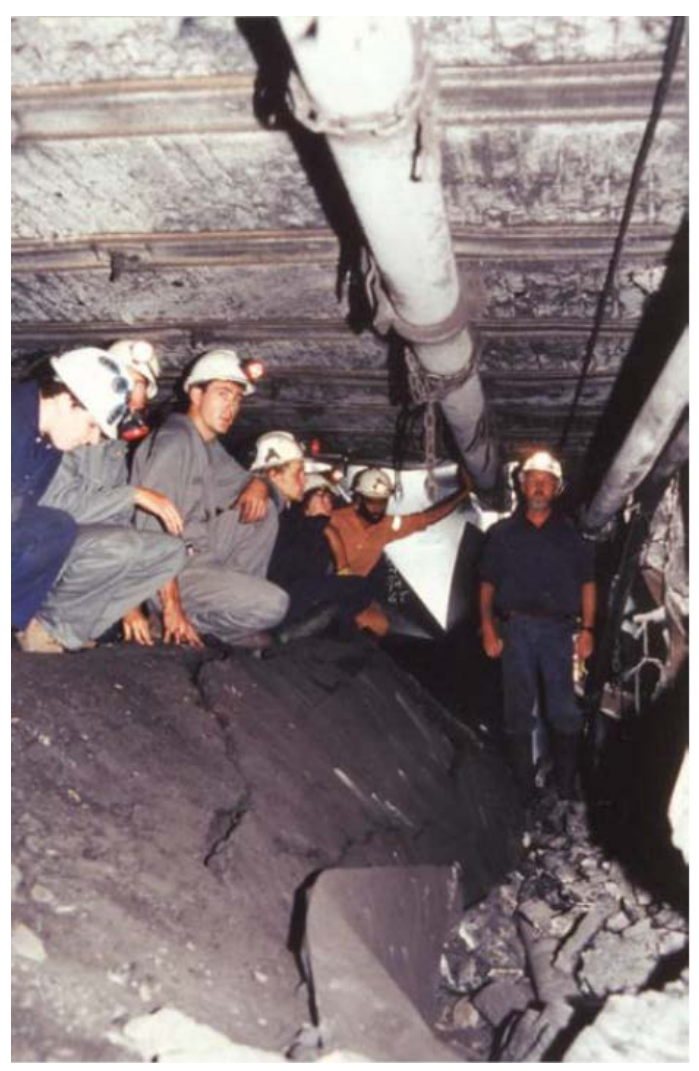

Figure 17. A rapid failure of a stiff immediate floor in a coal mine in Australia (Galvin, 2016).

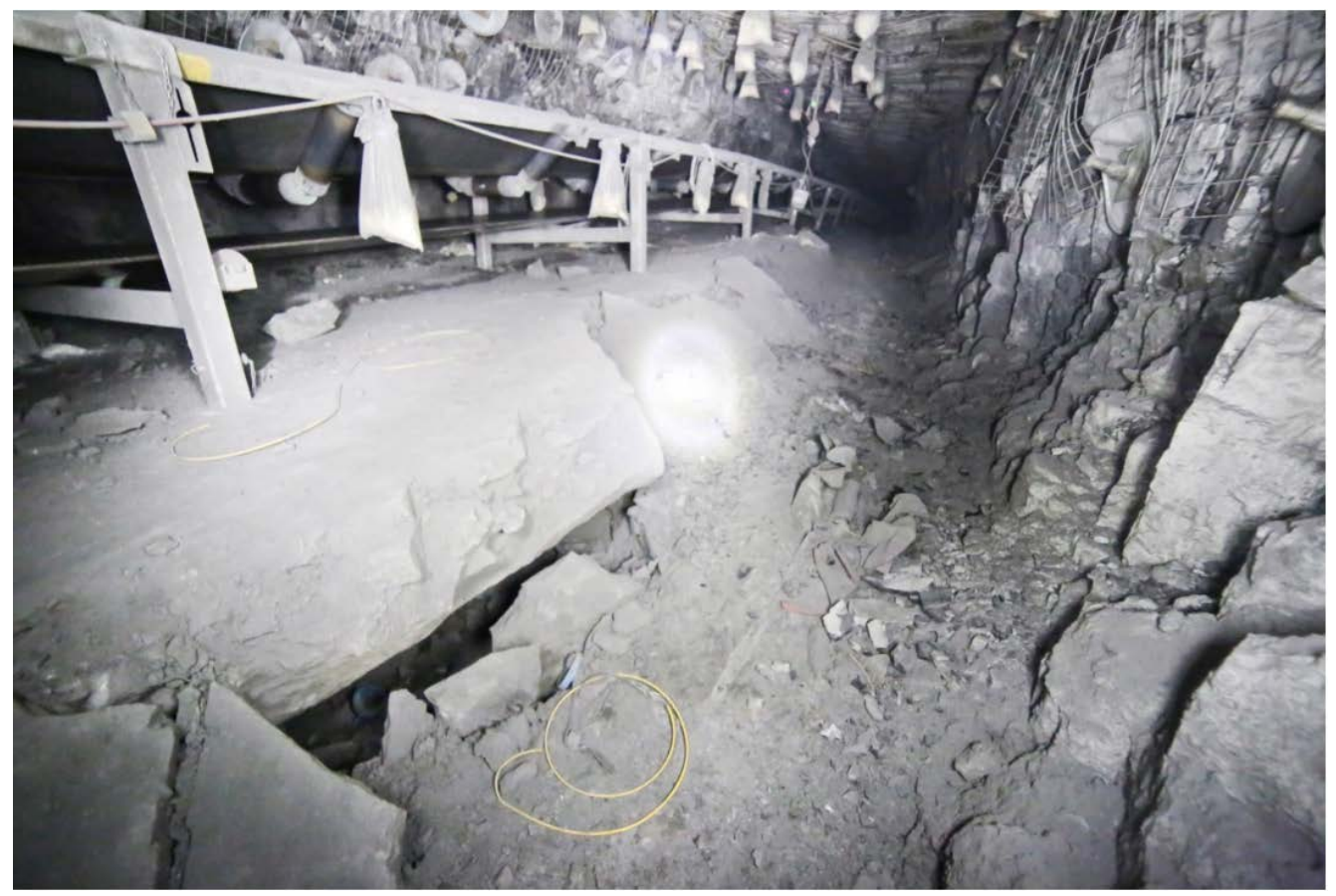

Figure 18. Floor buckling in Springvale mine in Australia (Sheffield and Corbett, 2018). 
Another recent severe floor heave was observed in the Blakefield South in the southwest of Singleton, located in the Hunter Valley of New South Wales, Australia (Figure 19) (Mo et al.,

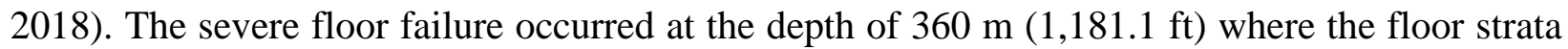
contained thick coal seam with an approximate thickness of $4 \mathrm{~m}(13.1 \mathrm{ft})$ and thin tuff layers; floor failure is associated with the buckling of thin tuff layers.

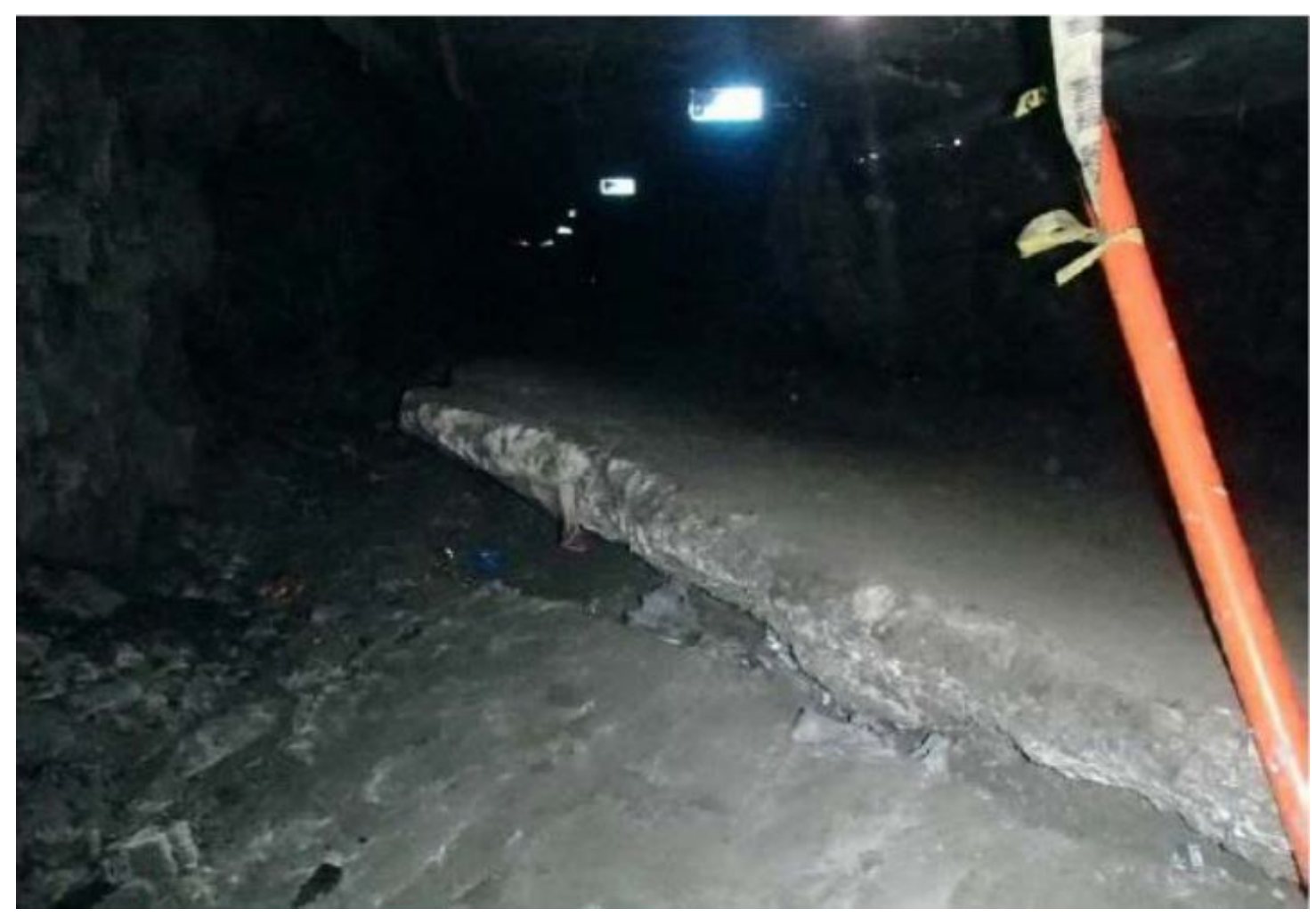

Figure 19. Excessive floor failure in Blakefield South, NSW (Mo et al., 2018).

\subsubsection{Other Floor Heave Mechanisms}

As mentioned in section 2.2., researchers have classified floor failure mechanisms differently over the years. In addition to the three floor failure mechanisms which were explained in the previous sections, floor heave associated with rock burst has also been encountered, although it is not as common as the bearing capacity, swelling buckling type of failures. Rock burst usually causes sudden failure with an intense and violent release of energy stored in the rock once the ultimate strength of the system is exceeded (Kaiser et al., 1996; Dou and He, 2001; Qi et al., 2013; Peng, 
2015). Further, rock bursts may result in a series of damages such as gas explosions, pillar failures, and floor heave. Figure 20 shows floor failure in roadways associated with rock burst.

Li et al. (2016a, 2016b) and Zhu et al. (2016) reported significant rock burst damages of approximately $400 \mathrm{~m}$ of roadway in Qianqui coal mine in China. Along with the rock burst, floor heave caused by the rock burst is also reported; the floor heave had exceeded $2 \mathrm{~m}(6.6 \mathrm{ft})$ at some parts of the mine over the course of 4 years. Another floor heave due to rock burst was encountered in a Canadian hard rock mine investigated by Cai and Champaigne (2012).

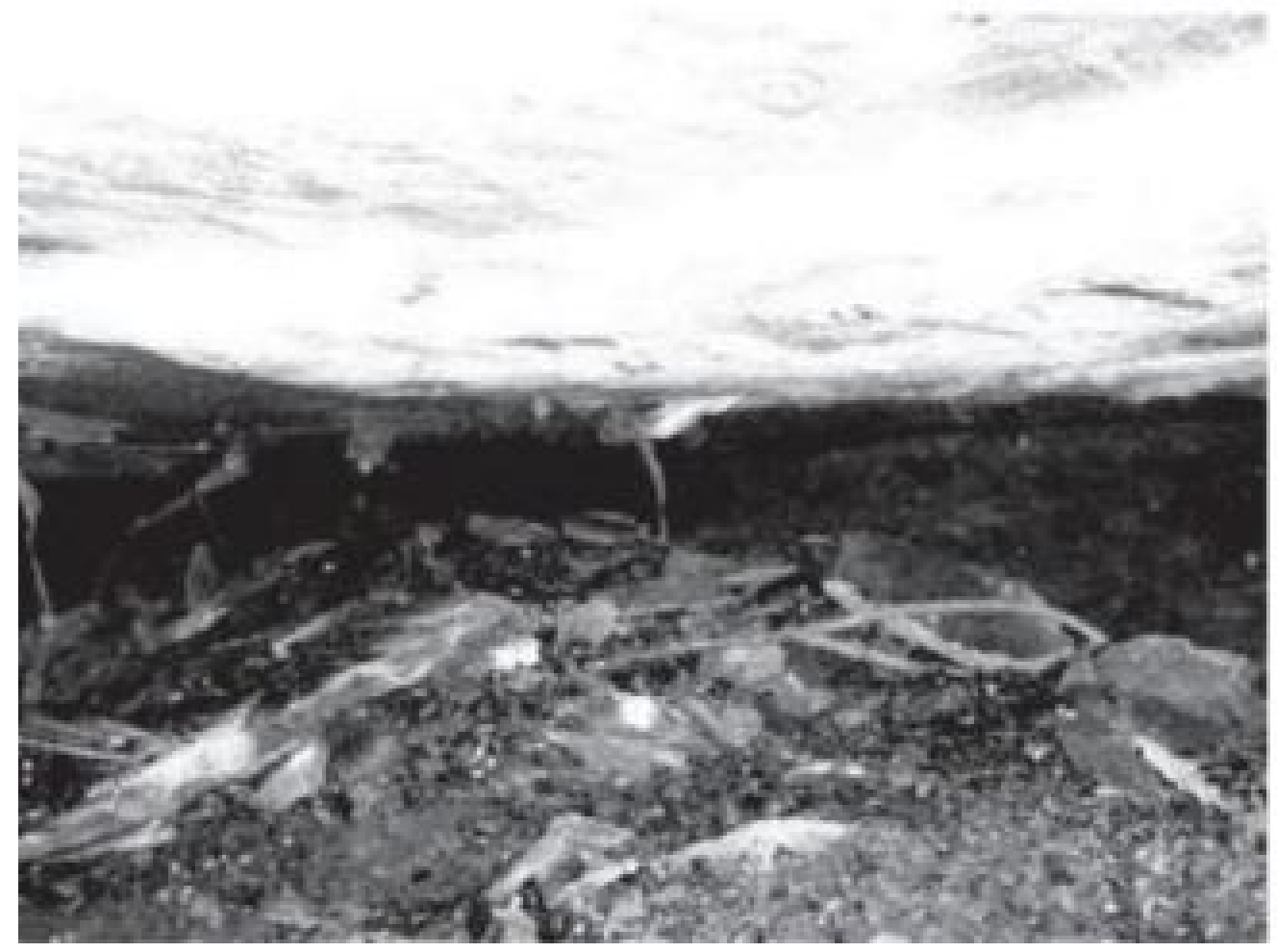

Figure 20. Floor heave associated with rock burst (Qi et al., 2013).

Furthermore, time dependent deformation of the floor-also called creep behavior — can be considered to be another floor failure mechanism which results in the gradual increase in floor deformation under constant load. Pytel (1998) claimed that bearing capacity analysis should be conducted to investigate the long-term effects of underclay floor material in floor stability which exhibits time-dependent deformation and is susceptible to creep failure, which in turn may result in roadway instability and surface subsidence. Chugh et al. (1987) and Vasundhara (1999) 
conducted research on the effect of creep behavior of floor rock in floor deformation, but they were not able to state the exact contribution of creep behavior to the overall floor heave.

\subsubsection{Non-coal Floor Heave Cases}

Floor heave occurs not only in coal mines, but also in hard rock mines. Pillar punching, floor heave, and subsequent roof fall and rib failure have been encountered in trona mines in the Green River Basin of southwestern Wyoming (Richardson et al., 1999). Figure 21 represents the consequent floor and roof failure. Failures are attributed to stronger and stiffer trona material than immediate roof, floor, and surrounding material.
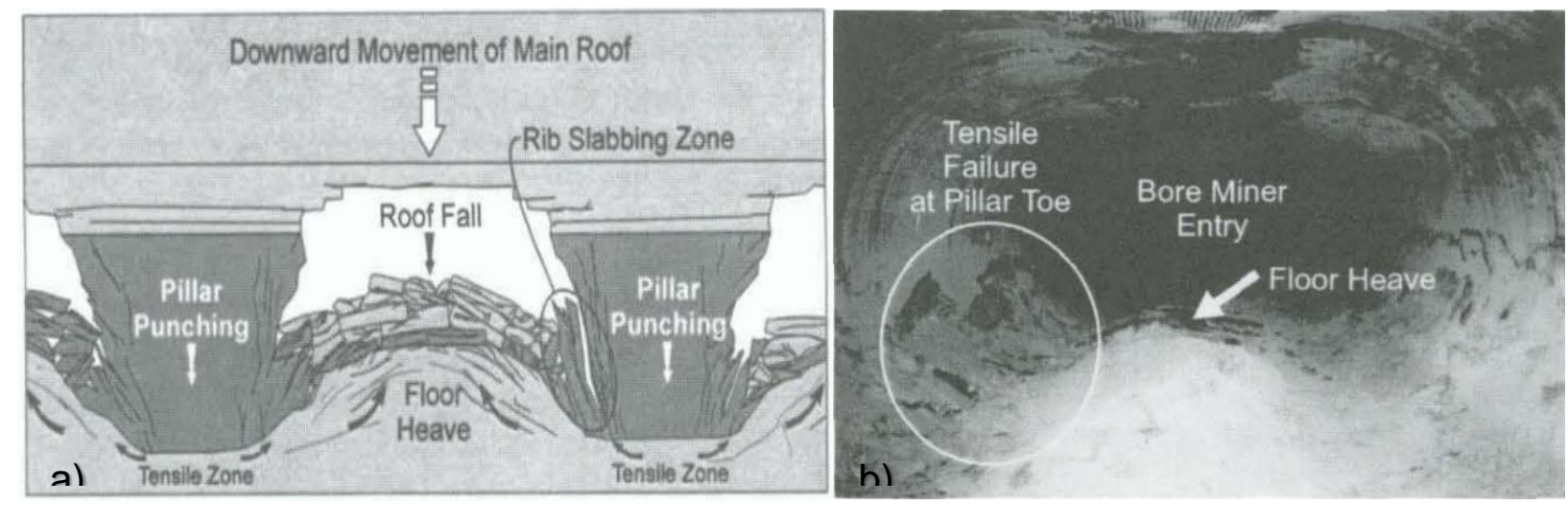

Figure 21. Floor and roof failure in trone beds in Wyoming: a) Roof-pillar-floor failure scheme (adopted Richardson et al., 1999) b) Floor heave as response to pillar punching (Richardson et al., 1999).

Bérest et al. (2008) stated that pillar punching into soft floor marls and surface subsidence were followed by a sudden panel collapse and subsequent large-scale roof and pillar deformation with a unique failure mechanism; this occurred at the Varangéville salt mine in Lorraine, France.

An extensive floor stability investigation took place in the Petersburgh underground limestone mine in Mahoning County in eastern Ohio, conducted by Murphy et al. (2015a, 2015b) and Slaker et al. (2015, 2017). The Petersburgh mine extracts the Vanport limestone seam at a depth of cover

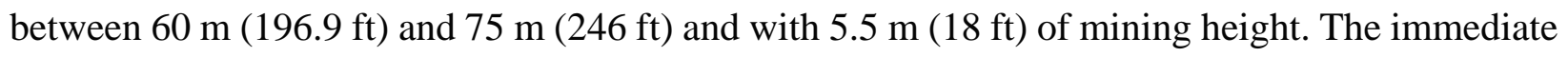
floor is weak blocky limestone and sandstone, while the immediate roof is limestone and shale. The excessive roof fall, including 10 pillars $60 \mathrm{~m}$ (196.9 ft) by $105 \mathrm{~m}$ (344.5 ft) in size, occurred 
and propagated to the surface within 2 hours and led to $1.5 \mathrm{~m}(4.9 \mathrm{ft})$ surface subsidence (Figure 22). After about a month, failure propagated and a second roof collapse occurred with additional roof failures of 10 pillars, and surface subsidence reached $2.7 \mathrm{~m}$ (8.9 ft) (Figure 24). These studies indicate that the existence of a weak floor with an approximate uniaxial compressive strength of 3 MPa (435 psi), and its exposure to the water under high horizontal stress played an important role in floor weakening. Tensile fractures in the bottom of the pillars, pillar sloughing at the corner, and the continuation of tensile fracturing in the upper pillar led to size reduction in the pillars (Figure 23a and Figure 23b). It is hypothesized that the decrease in pillar size increased the load applied to the floor which exceeded the load bearing capacity of pillars and resulted in floor cracks, punching the pillars into the floor and ultimately leading to wide-area collapse. This example clearly illustrates that a weak and moisture-sensitive floor extensively influences the overall integrity of the roof-pillar-floor structure and causes catastrophic consequences. The researchers recommended recognizing the existence of weak floor and water problems at the stage of mine design to place necessary precautions during mining.

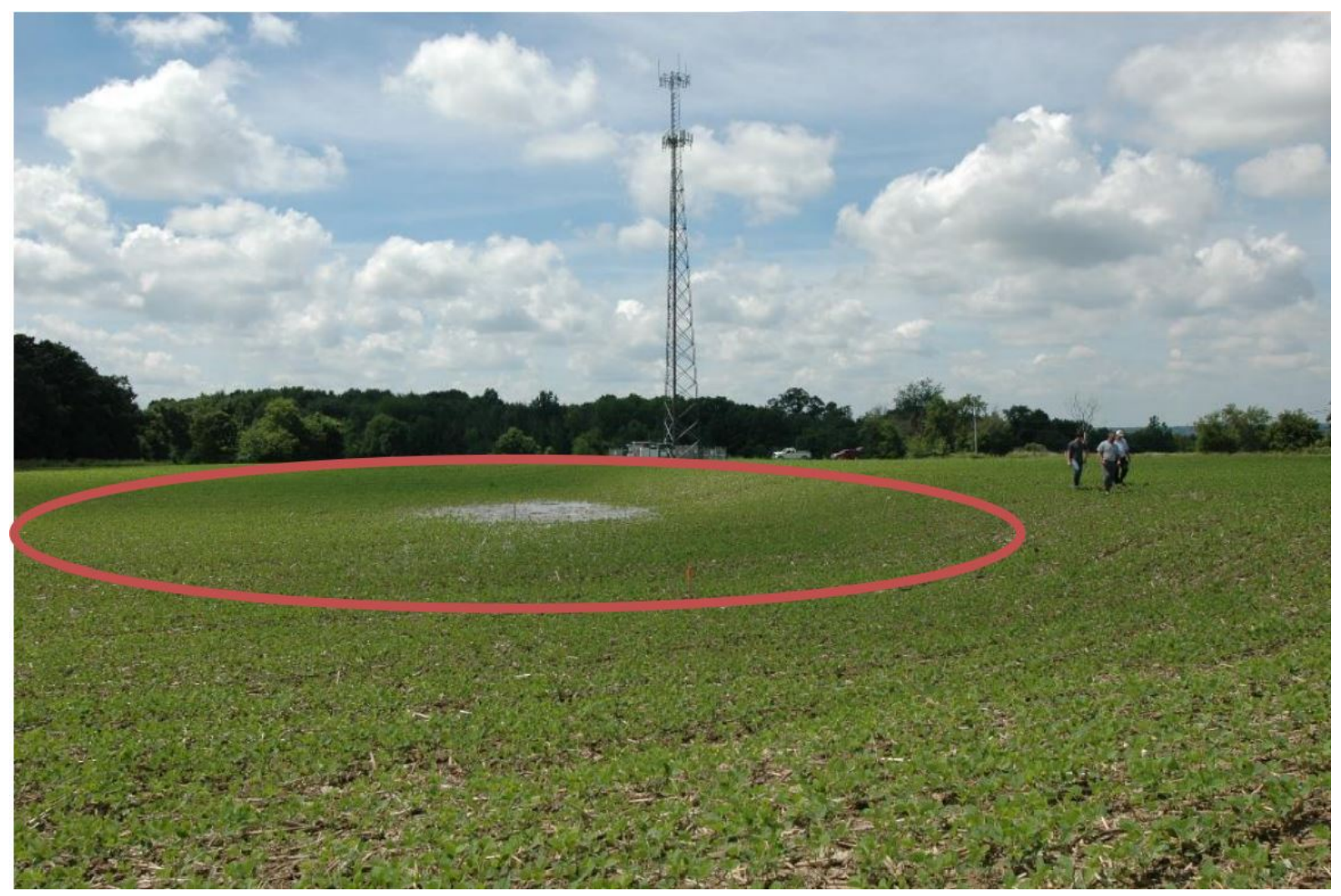

Figure 22. Surface subsidence in Petersburgh mine (Murphy, 2020). 


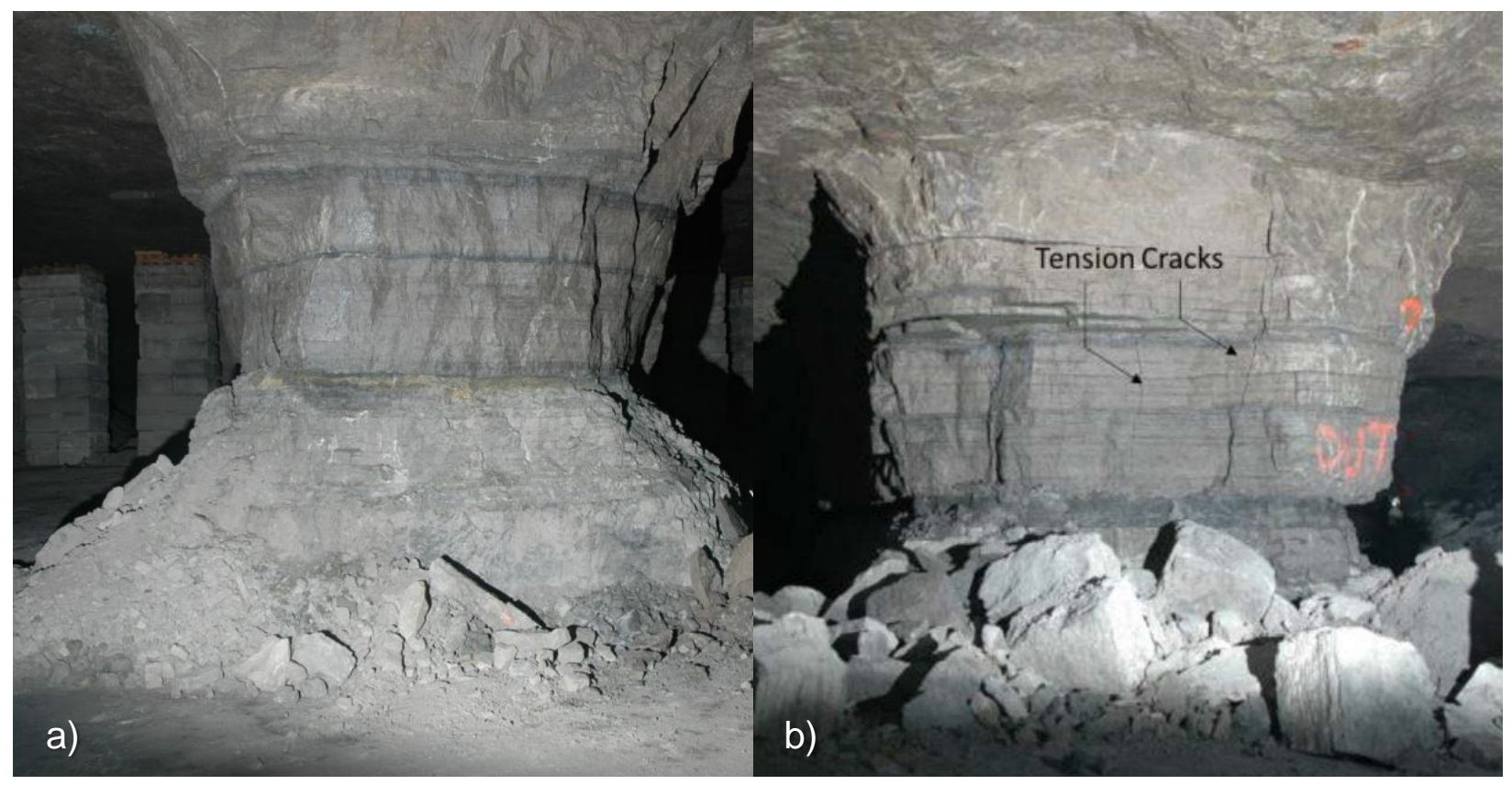

Figure 23. Petersburgh mine pillars: a) Size reduction, and b) tension cracks (Murphy, 2020).

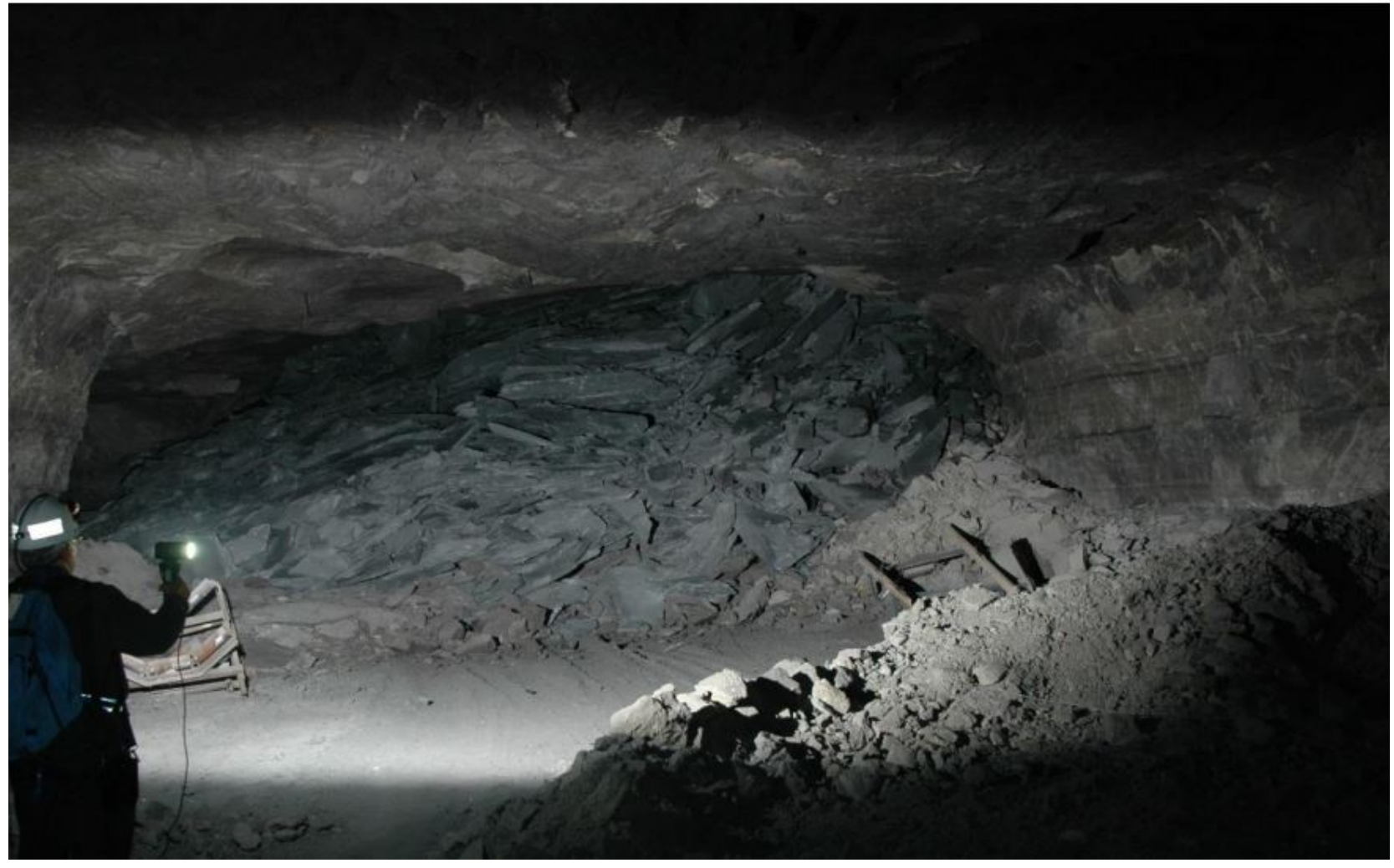

Figure 24. Massive roof collapse in Petersburgh mine in Ohio (Murphy, 2020). 
A year after the experience at the Petersburgh mine, the Subtropolis underground limestone mine-about a mile (1.6 km) away from the Petersburgh Mine in Ohio-experienced significant floor heave (Slaker and Murphy, 2018). The depth of cover in the Subtropolis mine ranges from $38 \mathrm{~m}$ (124.7 ft) to $55 \mathrm{~m}$ (180.4 ft). The Subtropolis mine shares the same general geology with the Petersburgh mine, but distinctly does not have problems associated with the existence of water and moisture-sensitive weak floor strata. The high horizontal stress played a major role in buckling of strata, as can be seen in Figure 25 and Figure 26.

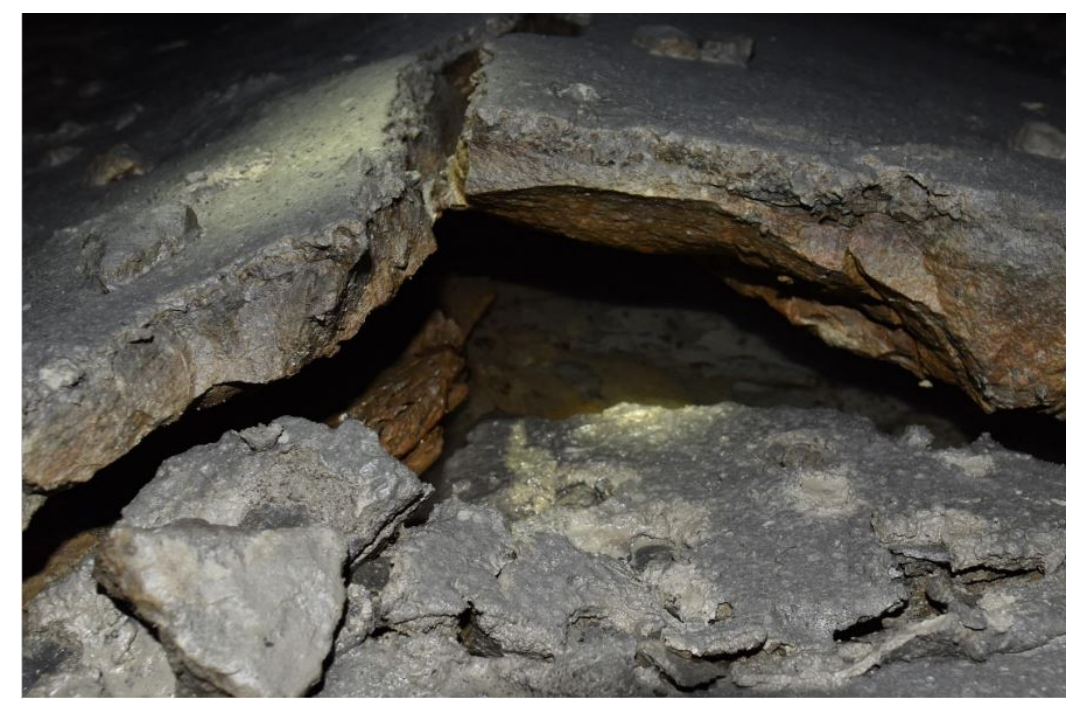

Figure 25. Buckled floor in Subtropolis mine in Ohio (Slaker and Murphy, 2018).

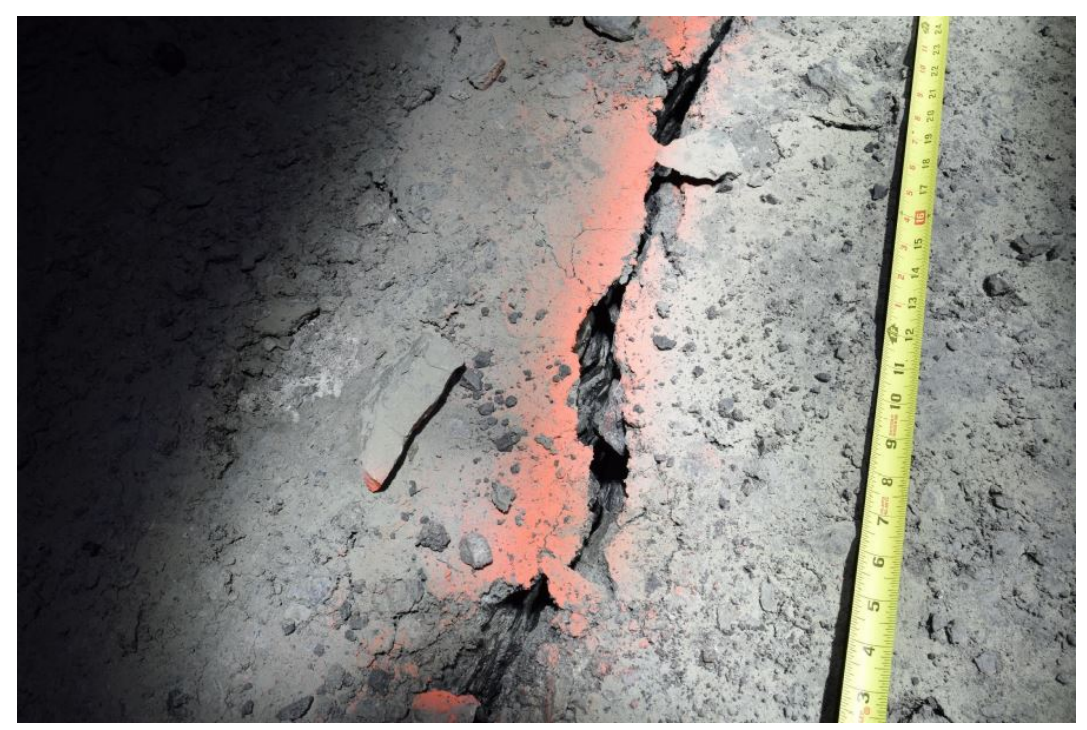

Figure 26. Floor crack at Subtropolis mine (Slaker and Murphy, 2020). 


\subsection{Rock Mass Classification Systems}

Hudson and Harrison (2000) define rock mass as "a complex geometrical and mechanical assemblage resulting from a long history of tectonic forces and other natural environmental effects.” Brady and Brown (2004) stated that understanding the complex nature of rock mass and making future predictions for rock mass response in advance is not simple. They support applying previous experiences of mining operations for future decisions in similar conditions. Towards this endeavor, rock mass classification systems based on empirical approaches have been developed in order to apply gained experience to similar conditions in other mines based on a standardized procedure.

Modelling the rock mass during rock engineering designs can aid in reducing possible ambiguities arising from heterogeneous nature and duplication of the effect of inherent spatial irregularities. Feng and Hudson (2011) classified the main rock engineering design approaches into eight rock mass modelling methods: pre-existing standard methods, analytical methods, basic and extended numerical methods, precedent type analysis, empirical classification, the database expert systems, and the integrated systems approaches. The empirical approaches originated from the rock mass classification systems whose application is widely accepted in many engineering works, particularly on tunneling, underground construction, and mining (Hoek, 2007). It is important to note that rock mass classification systems are not developed to substitute detailed engineering design procedures on the basis of field observations, as well as numerical and analytical methods. Although, there have been terrific accomplishments in the analytical and numerical computational tools for the geotechnical design of underground structures, specifying the proper input design parameters which reflect the characteristics of the rock mass is crucial (Heasley et al., 2010; Esterhuizen et al., 2010; Heasley, 2012; Sears and Heasley, 2013). Rock mass classification systems should be utilized as a tool along with other design methods in order to render the engineering design compatible with the nature of rock mass.

Rock mass classification systems began to be utilized in the late 1870s for tunnel design in order to incorporate rock properties into the design practices (Ritter, 1879). However, the earliest attempt to design tunnel support using a rock mass classification system based on qualitative methods was conducted by Terzaghi (1946). Terzaghi (1946) introduced a descriptive guideline, in cooperation 
with the Procter and White Steel Company, which classifies rock masses into seven groups to estimate the rock load on steel sets under different geological conditions. Hoek (2000) stated that Terzaghi's work served as a landmark guideline in tunnel design and construction for many years, providing a design basis for several tunnels particularly in North America. Lauffer (1958) stated that the rock mass quality governs the stand-up time of an unsupported tunnel span. Through modifications on Lauffer's classification system, a modern tunneling method called the New Austrian Tunneling Method (NATM) which aimed to keep tunnels stable using controlled stress release was developed by Rabcewicz (1964, 1965, 1975). Singh and Goel (1999) summarized the basic principles of the NATM. Shortly after the development of Rock Quality Designation (RQD) for quantitative description of rock from drill core (Deere et al., 1967), it began to be used in predicting tunneling conditions and selecting tunnel support (Deere et al., 1970). In addition, Deere et al. (1969a, 1969b), Peck et al. (1969), Cecil (1970), Cording and Deere (1972), and Merritt (1972) discussed the details of the application of RQD in tunnel support design.

Wickham et al. (1972) initiated assigning numerical ratings to rock mass properties using Rock Structure Rating (RSR), which has been a precursor to the RMR and the Q-system, both of which were widely accepted classification systems. Bieniawski (1973, 1989) introduced Rock Mass Rating (RMR) to define the support or excavation classes with a geomechanics classification system which employed six components: uniaxial compressive strength (UCS) of rock material, groundwater condition, RQD, condition of discontinuities, spacing of discontinuities, and joint orientation favorability. The application of RMR in the tunneling industry was discussed by Gonzalez de Vallejo (1983) along with new quality indexes, correction factors, and a few modifications of the RMR parameters. Aksoy (2008) documented the historical development and modifications of the RMR system conducted by Bieniawski (1973, 1989) and many other researchers. Later, Barton et al. (1974) developed the Q-system or Norwegian Geotechnical Institute (NGI) tunneling quality index to incorporate various aspects of rock material behavior into a single number based on approximately 200 case histories in tunneling. This system was employed to determine the most suitable rock support from a support chart. Similar to RMR, Qsystem also consists of six parameters: RQD, number of joint sets $\left(\mathrm{J}_{\mathrm{n}}\right)$, the most unfavorable joint roughness $\left(\mathrm{J}_{\mathrm{r}}\right)$, filling and alteration of the weakest joint set $\left(\mathrm{J}_{\mathrm{a}}\right)$, water inflow $\left(\mathrm{J}_{\mathrm{w}}\right)$, and stress condition (SRF). After its development, Q-system was modified several times due to additional 
observations and case histories (Barton, 1988; Grimstad and Barton, 1993; Barton and Grimstad, 1994; Barton, 2002; Norwegian Geotechnical Institute, 2015). Franklin (1970a, 1970b, 1975) proposed a two-parameter classification system with the emphasis on rock material strength and average fracture spacing. Palmström $(1995,2000)$ developed the Rock Mass Index (RMi) as a preliminary tunnel support selection method, considering ground water conditions and in situ stresses to describe the ground conditions. Hoek (1994) and Hoek et al. (1998) proposed the Geological Strength Index (GSI) to estimate rock mass strength through field observations to provide input parameters to tunnel design tools.

Tunnel boring is one of the major excavation methods used in tunnel construction as well as mining development in hard rock conditions. Bruland (1998) stated that hard rock tunnel boring machine (TBM) performance is related to machine parameters and rock mass properties. Various studies have been conducted for hard rock tunnel boring to investigate the relationship between rock material properties and penetrability (Graham, 1976; Farmer and Glossop, 1980; Cassinelli et al., 1982; O’Rourke et al., 1994; Rostami, 1997; Nelson et al., 1999; Cheema, 1999; Grima et al., 2000; Yagiz, 2002, 2008; Gong and Zhao, 2009). Rock mass classification systems started to be employed to incorporate the rock material properties to the prediction models in TBM tunnels. Barton (1999) introduced rock tunneling quality index by TBM excavation (Q Tвм) as an expansion of Q-system, in order to predict the penetration and advance rate of TBM. More recently, Von Preinl et al. (2006) introduced rock mass excitability (RME) as a tool to utilize in tunnel construction method selection between drill-and-blast and tunnel boring. Macias et al. (2015) stated that the Colorado School of Mines (CSM) model (Rostami and Ozdemir, 1993; Rostami, 1997) and the Norwegian University of Science and Technology (NTNU) model (Bruland, 1998) are widely accepted as a prediction method for cost and performance estimation in hard rock TBM tunneling. Many other rock mass classification systems developed as prediction models for hard rock TBMs can be found in alternate literature (Blindheim, 1979; Bamford, 1984; Innaurato et al., 1991; Sundaram et al., 1998; McFeat-Smith, 1999; Sapigni et al., 2002).

\subsection{Rock Mass Classification Systems in Mining}

There are several major differences between rock mass classification systems employed in tunneling and mining based on the nature of operations. The parameters which are often constant 
throughout a tunneling project, such as depth, tunnel orientation, and stress state, can be varied in mining projects due to the dynamic nature of mining. Milne et al. (1998) stated that if the joint orientation and stress condition is included in a rock classification system for mining operations, there have to be numerous classification numbers for the same rock mass due to distinct excavation sequence, mining level, and drift orientation. However, the application of rock mass classification systems in mining is still a necessity in order to understand behavior of rock mass and integrate it in empirical mine design. For this reason, many of the rock mass classification systems used in tunneling as described in the previous section are adjusted to mining applications through modifications and calibrations. Rock mass classification systems are used in many different areas in mining applications such as slope stability (Bieniawski, 1979; Romana, 1985; Romana et al., 2003), surface and underground mine design (Laubscher, 1990), support design and selection (Deere and Deere, 1988), geotechnical assessments, and mine development.

Deere (1963) conducted preliminary studies on the Rock Quality Designation (RQD) to quantitatively describe the quality of rock; however, the RQD methodology was not proposed in the 1963 paper since it was not conceived in its entirety. In 1967, the RQD concept was presented as a core recovery percentage to assess rock quality quantitatively from drill core logs (Deere et al., 1967). It is designed as a measure of rock competence considering the fractures and softening in the rock mass, and only intact rock pieces which have a length of larger than $100 \mathrm{~mm}$ were taken into consideration. The RQD is calculated as division of the summation of intact rock pieces with a length longer than $100 \mathrm{~mm}$ by the total length of core.

Bieniawski (1973) developed Rock Mass Rating (RMR) as a user-friendly and versatile technique which is applicable in several engineering practices to predict the rock mass behavior. In addition to RMR applications in tunneling as discussed in the previous section, RMR is a widely accepted design tool in mining projects as well. Several extensions of RMR in coal mining have been documented (Newman and Bieniawski, 1985; Unal, 1983; Newman, 1985; Venkateswarlu, 1986; Sheorey, 1991; Kalamaras and Bieniawski, 1995). RMR is calibrated continuously throughout its application in different engineering fields, from coal mining to the hard rock mining. For example, Mine Rock Mass Rating (MRMR) (Laubscher, 1975; Laubscher and Taylor, 1976) worked to convert the RMR into a design rock mass system for mines by adding factors for weathering, blasting, stress, and multiple joint orientations. Moreover, RMR is tailored to the hard rock mining 
environment, which was named Modified Basic RMR (MBR) (Kendorski et al., 1983). Through further modifications on RMR, Critical Span Curve (Lang, 1994) and drifting in very poor rock (Mathis and Page, 1995) were developed for underground support design in mining environments. Shortly after the development of RMR, Norwegian Geotechnical Institute developed Q-system (Barton et al., 1974). Since then, Q-system became a globally accepted method in support designs and kept being updated based on additional tunneling case histories. Although Q-system has been dominantly used in tunneling, the excavation design chart proposed during the modification by Barton and Grimstad (1994) has been applied in most of the mining applications (Milne et al., 1998).

For coal mines, the Coal Mine Roof Rating (CMRR) was developed by Molinda and Mark (1994) based mostly on case studies from Appalachian coal fields, typically with competent roof units for roof rock characterization and roof support selection purposes. Similarly, the Coal Mine Floor Rating (CMFR) was developed by Mo (2019) to evaluate the floor stability of Australian coal fields. Both will be explained in detail in the following sections.

\subsection{The Coal Mine Roof Rating (CMRR)}

The Coal Mine Roof Rating (CMRR) was proposed as a rock mass classification system for coal mine roof rock by the former U.S. Bureau of Mines (currently NIOSH) in order to characterize coal mine roof competency and prepare roof control plans with proper roof support systems (Molinda and Mark, 1993; Molinda and Mark, 1994; Mark and Molinda, 2005). The CMRR was developed based on mining case histories from all major coal basins across the United States, predominantly Appalachian coal fields with strong roof units.

The CMRR converts descriptive geologic information of coal mine roofs into a numerical index which can be directly used in ground control plans and mine designs. Similar to Bieniawski’s RMR system, the CMRR combines various individual ratings and its index ranges from 0 to 100 , where 100 refers to competent and solid roof rock. The CMRR can be calculated using information gathered during site visits to the interested roof area, or alternatively using the geologic drill core log data and laboratory tests if access to the mine is unavailable or limited. CMRR represents the roof rock competency with or without consideration of the moisture sensitivity effect through wet and dry CMRR, respectively. The decision to utilize wet or dry CMRR should be decided case by 
case. For example, if there is no moisture sensitive rock present in the roof strata, if the atmosphere in the mine is not humid, or if there is no water or solution applied to the roof rocks, dry CMRR is used for rock mass representation.

\subsubsection{The CMRR Components and Calculation}

CMRR is composed of several parameters and adjustment factors with various significance, similar to many other rock mass classification systems. The application of the CMRR is conducted in three stages: input field data collection, calculating unit ratings (UR) and roof rating (CMRR), and evaluation of results (Molinda and Mark, 1994). Upon collecting the input field data, CMRR is calculated as a two-step process. The first step is calculating the unit rating of each individual geotechnical unit within the bolted interval. Unit rating is a function of discontinuity shear strength, discontinuity intensity, compressive strength, multiple discontinuity adjustments, and weatherability. The second step is calculating the thickness-weighted average of unit ratings within the bolted area, which is the CMRR. CMRR analysis considers the roof units within the bolted interval as a single structure and disregards the further parts of the roof which exceed the top of the bolt in the roof stability analysis. Therefore, CMRR is dependent on the bolted horizon, which means if the bolt length is increased and anchored in a competent unit in the immediate roof, the CMRR value changes. The roof competency is classified into three major groups using CMRR by Molinda and Mark (1994):

CMRR < 45: Weak roof

$45<$ CMRR < 65: Moderate roof

CMRR > 65: Strong roof

\subsubsection{CMRR Applications}

CMRR has been extensively used both inside and outside the U.S. for a large variety of design purposes. In the U.S., it is frequently used for extended cut design, roof support selection, longwall pillar design, longwall gate road design, hazard mapping, mining method selection, feasibility studies, and multiple seam mine design. Karabin and Evanto (1994) used CMRR in order to represent the rock mass properties of roof material as an input to numerical models. De Marco (1994) used CMRR to analyze applicability of yielding gate road systems in an Eastern U.S. 
longwall mine. Chase et al. (1994) applied the CMRR to assess massive pillar collapse. Beerkircher (1994) used CMRR in feasibility studies of Monterey Coal Company’s longwall project. Signer (1994), Mark (2000), and Mark and Barczak (2000) used the CMRR to evaluate the field performance of grouted roof bolts. Wuest et al. (1996) incorporated the CMRR into hazard map analysis. Luo et al. (1997) included the CMRR in multiple seam design guidelines. Deb (2003) studied the relationship between CMRR, primary roof support (PRSUP), and intersection diagonal span. CMRR is an input parameter for design software frequently used by the mining industry and regulatory agencies, such as the Analysis of Longwall Pillar Stability (ALPS) (Mark and Molinda, 2005), the Analysis of Roof Bolt Systems (ARBS) (Mark et al., 2001), the Analysis of Longwall Tailgate Serviceability (ALTS) (Colwell et al., 1999), and the most recently updated ALTS II (Colwell et al., 2003).

\subsection{The Coal Mine Floor Rating (CMFR)}

The Coal Mine Floor Rating (CMFR) is a newly proposed floor classification system which aims to provide insight into floor heave mechanisms and assess the floor stability of Australian coal mines (Mo, 2019). The CMFR is developed by integrating the structure of the CMRR into the CMFR with slight variations and modifications. The CMRR uses a bolted interval concept in order to identify the thickness of the immediate roof which will be taken into consideration during CMRR calculations. However, as the application of bolts in floor strata is very rare, the existence of a bolted area concept that is used in CMRR for floor strata is not applicable. Instead, the CMFR focuses on the first $3 \mathrm{~m}$ (10 ft) interval of floor strata starting from the floor surface to assess the

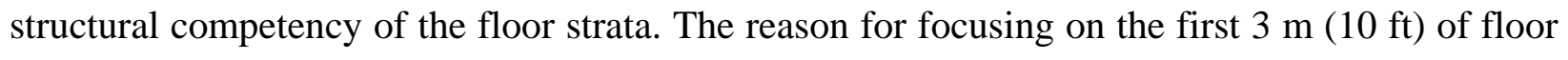
in the CMFR calculation is explained by Mo (2019) using the occurrence of a major floor deformation below $3 \mathrm{~m}$ (10 ft) from floor surface measured by in situ floor monitoring in an Australian coal mine (Sheffield and Corbett, 2018). Mo (2019) supported his suggestion by numerical model results, which showed that units below $3 \mathrm{~m}(10 \mathrm{ft})$ are less likely to fail compared to the units in the first $3 \mathrm{~m}(10 \mathrm{ft})$ interval.

The CMFR was developed by investigating 28 failure and 30 non-failure case histories from 5 different longwall mines in New South Wales and Queensland, Australia. The CMFR system is composed of two major empirically created components: Coal Mine Floor Rating (CMFR) and 
Horizontal Stress Rating (HSR). CMFR was created to quantify the competence of floor, and HSR was created to include the effect of overburden stress and alignment of maximum principal horizontal with respect to the entries. In order to assess the stability of the floor in comparison with other failure and non-failure cases in the database, Floor Heave Index (FHI) was created, which incorporates the CMFR and HSI into a design line. FHI is employed to depict the correlation between CMRR and failure/non-failure cases from the Australian database based on a logistic regression model.

\subsubsection{The CMFR Components and Calculation}

The CMFR is designed to represent the competency of floor strata by merging important geomechanical and lithological properties of immediate floor rocks into a single numerical value. First, the CMFR divides the floor strata into different geotechnical floor units based on the geological differences between units and calculates a unit rating for each layer.

Uniaxial compressive strength of intact rock and discontinuity characteristics, more specifically the average discontinuity spacing of beddings and other discontinuities, are the main parameters used in the computation of unit ratings. Then, the thickness-weighted average of unit ratings is calculated. Since the configuration of the strong unit in floor strata also affects the overall behavior of the floor, the effect of the strong unit is integrated into the CMFR through strong unit adjustment (SUA).

\subsubsection{UCS}

Uniaxial compressive strength (UCS) is widely used by a large percentage of rock mechanics engineers to represent the strength of rock for surface and underground designs. UCS can be obtained through indirect tests, such as point load test, Schmidt hammer test, sonic logging, and so on. Sliwa et al. (2006) states that sonic logging has become an increasingly widespread method for rock strength estimation in Australia. Analogously, the CMFR system recommends using the UCS rating scale for the UCS values obtained by sonic logging (Table 1). It is believed that the competence of floor stratum with less than $10 \mathrm{MPa}(1,450 \mathrm{psi})$ is governed only by UCS, i.e. not influenced by the average discontinuity spacing any longer. Riefenberg (1995) asserted that floor strength significantly influences the floor deformation and suggested assigning a greater weighting 
to floor strength in CMFR compared to the assigned weighting given to roof strength in the CMRR. To that end, UCS Rating in the CMRR generates 65\% of the CMRR value.

Table 1. CMFR ratings for UCS.

\begin{tabular}{cc}
\hline UCS (MPa) & UCS Ratings \\
\hline$<10$ & 10 \\
10 to 20 & UCS +10 \\
20 to 30 & $0.3 \times$ UCS +31 \\
30 to 80 & $0.125 \times$ UCS +45 \\
80 to 160 & 65 \\
$>160$ & \\
\hline
\end{tabular}

\subsubsection{Discontinuity Spacing}

In rock engineering, two main classification terms exist to define rocks: intact rock and rock mass (Priest, 1993). Intact rock refers to the rock material in an ideal state where there is not any discontinuity or fracture (massive) in the rock matrix, whereas rock mass refers to rock material in in situ conditions with a possible discontinuity/fracture network. For the sake of simplifying the engineering process, rock masses are sometimes assumed to be intact rock. However, in real-world applications, discontinuities always exist within the rock matrix.

Discontinuities in rock engineering mechanics serve as an inclusive term of all fractures, such as faults, joints, shears, weak bedding planes, and contacts (Brady and Brown, 2004). The intensity of weakness planes within the rock governs the mechanical behavior of rock mass in the sense that densely packed planes of discontinuities adversely affect the strength of rock mass (Hoek and Brown, 1997). Therefore, discontinuity properties, more specifically discontinuity spacing, are commonly used as a measure of rock mass quality and employed in many rock mass classification systems.

In CMFR, discontinuity spacing is applied to implicate frequency of weakness planes, including bedding, lamination, joints, fractures, and any other kind of planes that result in weakness in a rock mass. Discontinuity spacing can be measured through different methods, such as distance between 
two individual discontinuities or distance between a single discontinuity and a set of other discontinuities. In CMFR, discontinuity spacing is expressed in terms of average distance between discontinuities in a floor unit. Discontinuity spacing, which is the average distance between each discontinuity plane per unit length along a drill core, can be calculated by dividing the number of discontinuities with the unit thickness of the layer. The CMFR system scale for discontinuity spacing is shown in Table 2.

Table 2. CMFR rating for discontinuity spacing.

\begin{tabular}{cc}
\hline $\begin{array}{c}\text { Discontinuity Spacing } \\
\text { (S) (mm) }\end{array}$ & $\begin{array}{c}\text { Discontinuity Spacing } \\
\text { Rating }\end{array}$ \\
\hline $\mathrm{S}<20$ (lamination) & 0 \\
$20 \leq \mathrm{S}<60$ & 5 \\
$60 \leq \mathrm{S}<200$ & 15 \\
$200 \leq \mathrm{S}<600$ & 25 \\
$\mathrm{~S} \geq 600$ & 35 \\
\hline
\end{tabular}

CMFR calculation begins with the evaluation of Unit Ratings, which is a summation of a UCS Rating (Table 1) and a Discontinuity Spacing Rating (Table 2). A minimum Unit Rating of 25 is applied to all floor units. A Unit Rating of 40 is given to the units with UCS less than $10 \mathrm{MPa}$ (1,450 psi). Upon the calculation of Unit Ratings for each floor stratum, a Strong Unit Adjustment can be added to the corresponding strong unit. Next, the thickness-weighted average of Unit Ratings is calculated within the $3 \mathrm{~m}$ (10 ft) of floor strata in order to achieve an overall CMFR number based on a 0-100 scale, which represents the competence of the floor strata within $3 \mathrm{~m}$ (10 $\mathrm{ft}$ ). Table 3 represents the calculation of the Unit Rating of each stratum and thickness-weighted average of Unit Ratings for an available geologic drill core logs from a case study mine. It should be noted that the last $0.27 \mathrm{~m}(0.9 \mathrm{ft})$ of the bottom unit with a thickness of $0.55 \mathrm{~m}(1.8 \mathrm{ft})$ is excluded from the CMFR calculation as it is not within the $3 \mathrm{~m}(10 \mathrm{ft})$ of floor strata. 
Table 3. Calculation procedure of unit rating and CMFR.

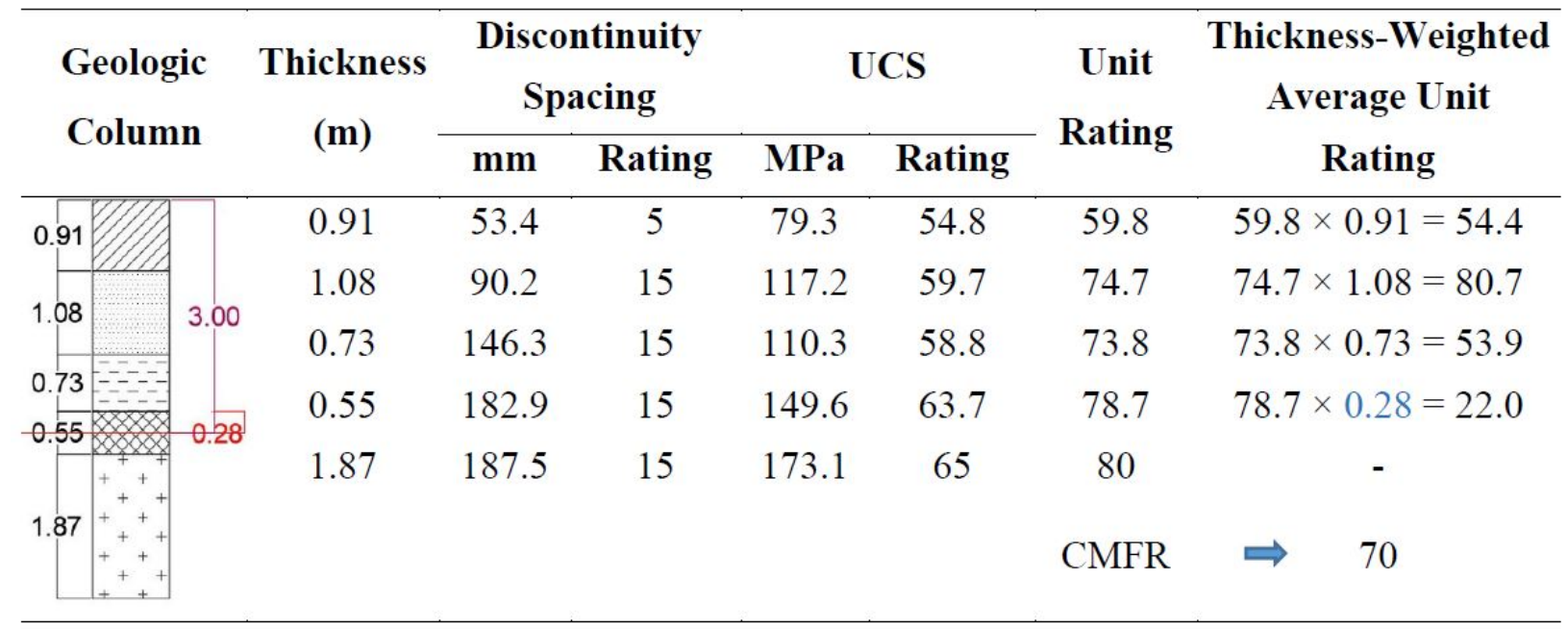

\subsubsection{Strong Unit Adjustment}

In the stratified depositional nature of coal mine roof and floor geology, it is likely to be several different units with varying geomechanical properties. Mark and Molinda (2007) state that the strongest layer within the bolted area in the roof heavily influences the roof performance. Similarly, the presence of a strong unit in the floor strata is considered by the CMFR system while estimating the competence of floor strata. Since the application of bolts in floor strata is very rare, the bolted interval concept used in the CMRR cannot be implemented to the CMFR. Instead, the first 1-m ( $3.3 \mathrm{ft}$ ) interval of floor strata is taken into consideration in order to investigate the effect of a strong unit on floor performance. Including the adjustment for a strong unit depends on the stratigraphic sequence of strong units within $1 \mathrm{~m}$ (3.3 ft) of floor strata. In order to apply the Strong Unit Adjustment (SUA) calculation, the strongest layer should be within the $1 \mathrm{~m}$ (3.3 ft) of floor

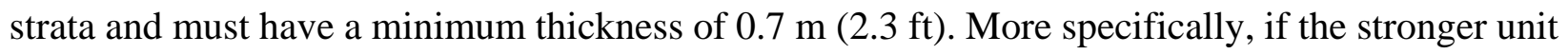
with the highest Unit Rating is located within the $1 \mathrm{~m}$ (3.3 ft) of floor strata but its thickness is less

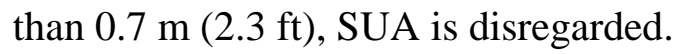

CMRR considers how much stronger a strong unit is than the others present in the strata (Mark and Molinda, 2007). Analogously, CMFR distinguishes the strongest layer with the highest Unit Rating. Then, the Strong Unit Difference (SUD) calculation is established to evaluate the relative strength of layers. The SUD is calculated by subtracting the Unit Rating of the strong layer from the thickness-weighted average of Unit Ratings within $3 \mathrm{~m}(10 \mathrm{ft})$ of floor strata. If the SUD is 
greater than 20, 5 is added to the thickness-weighted average of Unit Ratings as SUA, and the new sum is used as a CMFR number.

\subsubsection{Horizontal Stress Rating}

According to the Floor Heave Index (FHI), an empirical proxy which incorporates the CMFR and the HSR into one graphical output, stress applied to the floor is as important as the floor material quality to assess floor stability in a coal mine. In order to include the stress state of the floor into the FHI system, Horizontal Stress Rating (HSR) is established. The HSR is composed of Depth Rating and Angle Rating.

Depth Rating is simply the division of depth of cover in meters by 10 . Angle refers to the angle between the entry and major principal horizontal stress. The Angle Rating scale for the HSR is shown in Table 4.

Table 4. CMFR rating for angle.

\begin{tabular}{cc}
\hline $\begin{array}{c}\text { Angle of major principal } \\
\text { stress to the entry, } \boldsymbol{\theta}\left(^{\circ}\right)\end{array}$ & Angle Rating \\
\hline$\theta<10^{\circ}$ & 0 \\
$10^{\circ} \leq \theta<20^{\circ}$ & 1 \\
$20^{\circ} \leq \theta<30^{\circ}$ & 3 \\
$\theta>30^{\circ}$ & 5 \\
\hline
\end{tabular}

For instance, HSR for a case study with a $300 \mathrm{~m}$ (984 ft) depth of cover and a $35^{\circ}$ angle between entry and major principal horizontal stress is calculated as a summation of 30 and 5, or 35.

\subsubsection{Floor Heave Index}

The Floor Heave Index (FHI) is an empirical method developed from the logistic regression model. The FHI is employed in order to combine the CMFR value and HSR into one output. Incorporating the CMFR and the HSR of failure and non-failure cases into the FHI provides a visual comparison of binary outcomes of failure and non-failure cases using the logistic line.

The FHI was developed for case study mines in Australia, shown in Figure 27 (Mo, 2019). The zone above the line represents floor heave cases, while the zone below the line indicates minor or 
no floor heave. The addition of new case studies using the FHI by calculating CMFR and the HSR can assist in the estimation of floor stability conditions of other mines for future geotechnical investigations.

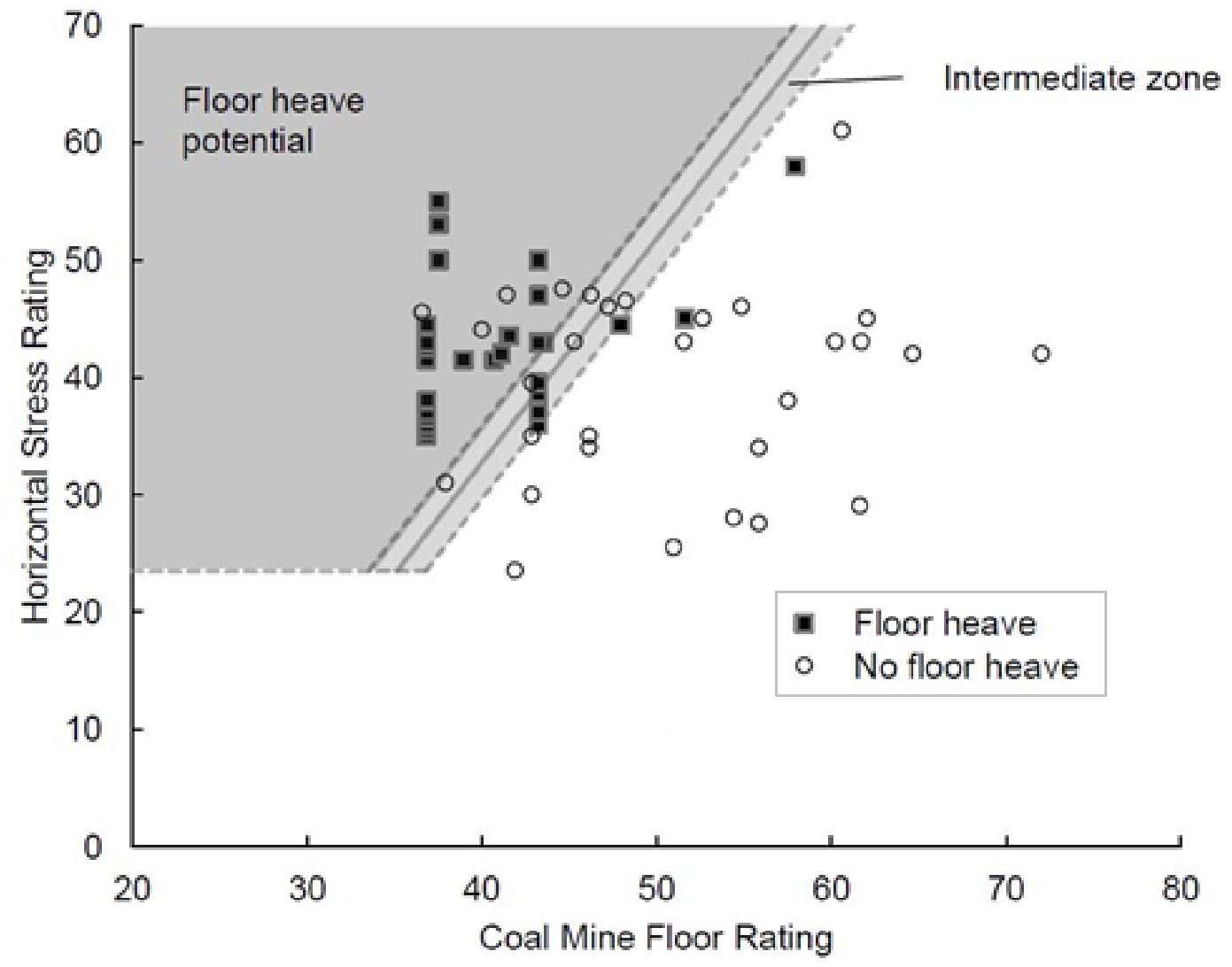

Figure 27. Floor Heave Index for Australian coal mines (adopted from Mo, 2019).

\subsubsection{CMFR Application in Australia}

As presented in Figure 27 above and stated by Mo (2019), CMFR values for the Australian studies vary from 37 to 52, while HSR ranges between 23.5 and 61. The case study database is composed of only floor failures with buckling mechanisms. Therefore, it should be stressed that FHI is created only based on the cases with buckling mechanism; it is not recommended to apply FHI for cases with different mechanisms, such as bearing capacity failure and swelling. Since the CMFR is a newly proposed rock mass classification system, CMFR has not been applied to other cases, both in Australia and globally. This study aimed to be the first application example of CMFR for a coal mine floor stability evaluation outside of its database. 


\section{Chapter 3 Case Histories}

\subsection{Data Collection}

Four case stories gathered from various underground coal mines in Eastern U.S. were compiled into a single database, containing Mine A, Mine B, Mine C, and Mine D, in order to assess the applicability of the CMFR in Eastern U.S. coal mines. Both floor failure and non-failure cases are included in the database. The backbone of this study is the compilation of a case history database, since there has not been any published database related to floor failure in the Appalachian Basin. Case study mines are visited to gather input information, which is required for the CMFR and stability evaluation. After site investigations were conducted at the case study mines, the information which is pertinent to this thesis is demonstrated in the following chapters. Meanwhile, the potential failure mechanism is verified as a buckling type of floor heave. During the mine visits, mine plans, dimension of entries, general mining properties, geologic drill core log data, strength test of floor units, and geologic core log pictures are acquired. Additionally, any sitespecific features such as the existence of nearby water sources or fault zones are discussed by miners, geologists, and engineers. In this chapter, four case histories are concisely presented to demonstrate insight into the case histories.

\subsection{Mine A}

\subsubsection{Background}

Mine A is located in Virginia. Low-vol metallurgical coal is extracted from Pocahontas No. 3 coal seam by utilizing the longwall mining method. According to the Mine Safety and Health Administration (MSHA) data retrieval system (MSHA, 2020), Mine A produced 4.71 million tonnes (5.19 million tons) and 4.48 million tonnes (4.94 million tons) of bituminous coal in 2018 and 2019, respectively.

Figure 28 illustrates the mine panel geometry in the close vicinity of floor heave. The longwall panels are extracted from bottom to top and extraction advances from left to right through the mine. Due to the split in the top of the seam, which led to a very weak clay roof, the direction of mine advance was changed and oriented $45^{\circ}$ towards the south starting from Panel 25. The coal seam is $1.5 \mathrm{~m}$ ( $4.9 \mathrm{ft})$ to $1.8 \mathrm{~m}$ ( $5.9 \mathrm{ft})$ in thickness. The overburden thickness throughout the mine 
ranges from $548.6 \mathrm{~m}(1,800 \mathrm{ft})$ to $731.5 \mathrm{~m}$ (2,400 ft). A four-entry gateroad system is used between panels. The width of the entry is $6.1 \mathrm{~m}$ ( $20 \mathrm{ft}$ ). The longwall panels are approximately $220 \mathrm{~m}$ (721.8 $\mathrm{ft})$ wide by 3,660 $\mathrm{m}(12,007.9 \mathrm{ft})$ long. In the studied part of the mine, the depth of cover ranges from $609.6 \mathrm{~m}(2,000 \mathrm{ft})$ and $731.5 \mathrm{~m}(2,400 \mathrm{ft})$.

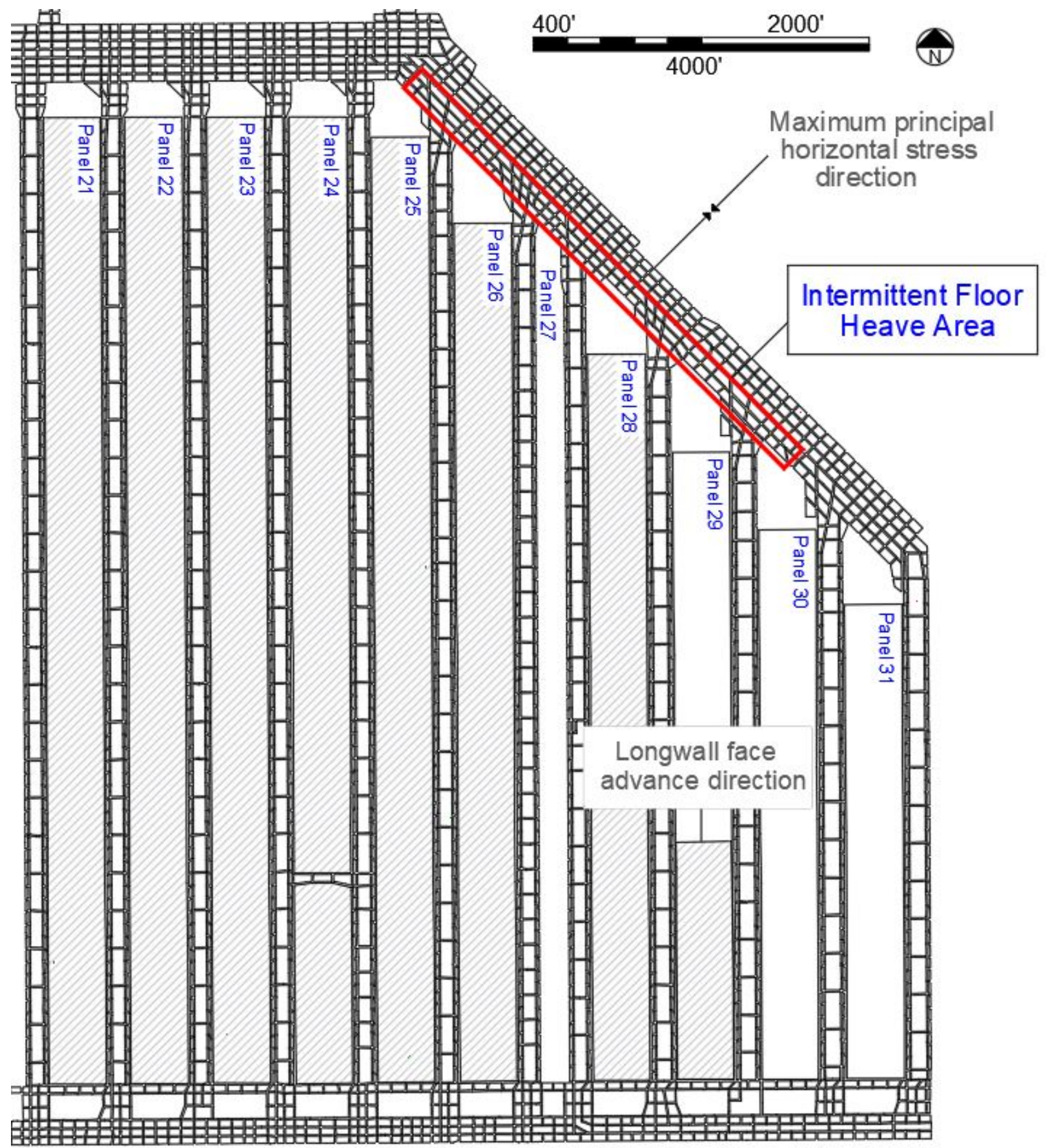

Figure 28. Geometry of longwall panels at Mine A. 


\subsubsection{Regional Geologic Setting}

Mine A is in the Central Appalachian basin. The Pocahontas No. 3 coal seam, which is being extracted by Mine A, is in the Pottsville Group (Lower Pennsylvanian Pocahontas, New River Formations, and Middle Pennsylvanian Kanawha Formation) of the Pocahontas Formation. As noted from Figure 29, the Pocahontas Formation involves more than 20 coal seams in Southern West Virginia and Virginia, including the Pocahontas No. 1 to No. 7 coal seams. The thickness of the Pocahontas Formation ranges from $213 \mathrm{~m}(698.8 \mathrm{ft})$ to $274 \mathrm{~m}$ (899 ft). Furthermore, the Pocahontas Formation typically consists of sandstone with lesser amounts of siltstone, shale, and coal.

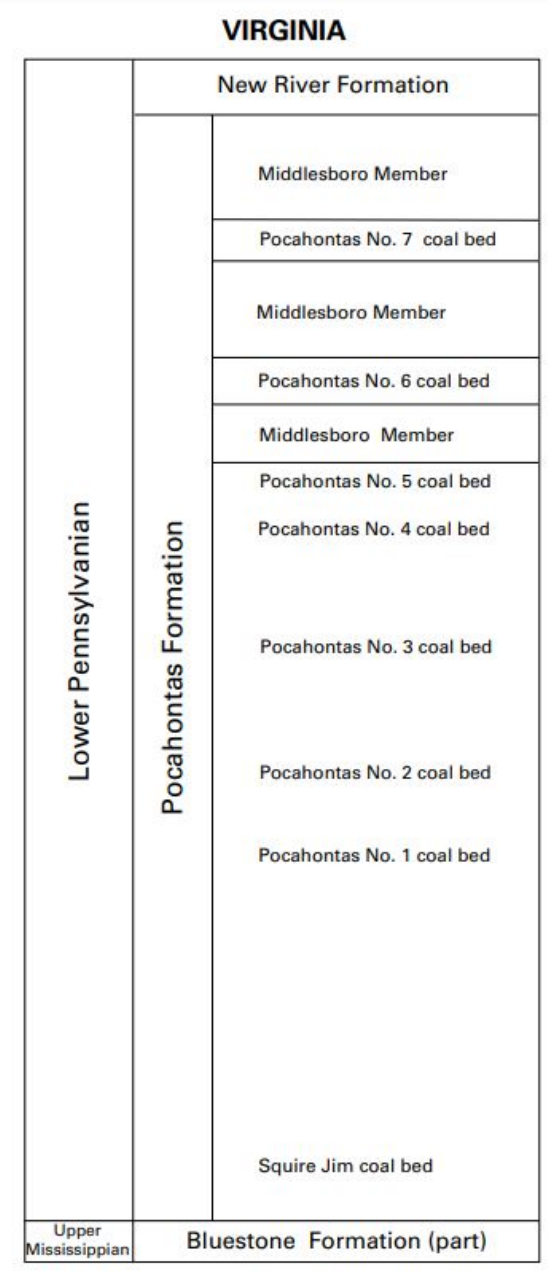

\begin{tabular}{|c|c|c|}
\hline \multicolumn{3}{|r|}{ WEST VIRGINIA } \\
\hline \multirow{18}{*}{ 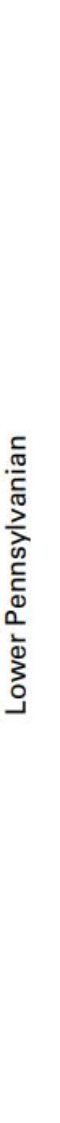 } & & New River Formation \\
\hline & \multirow{17}{*}{ 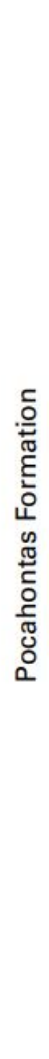 } & Flattop Mountain Sandstone Member \\
\hline & & Rift shale \\
\hline & & Pocahontas No. 7 coal bed \\
\hline & & Pierpont sandstone \\
\hline & & Royal shale \\
\hline & & Pocahontas No. 6 coal bed \\
\hline & & Eckman sandstone \\
\hline & & $\begin{array}{l}\text { Pocahontas No. } 5 \text { coal bed } \\
\text { Pocahontas No. } 4 \text { coal bed } \\
\text { Upper Pocahontas sandstone }\end{array}$ \\
\hline & & Pocahontas No. 3 rider \\
\hline & & Pocahontas No. 3 coal bed \\
\hline & & Lower Pocahontas sandstone \\
\hline & & $\begin{array}{l}\text { Pocahontas No. } 2 \mathrm{~A} \text { coal bed } \\
\text { Pocahontas No. } 2 \text { coal bed }\end{array}$ \\
\hline & & Vivian sandstone \\
\hline & & $\begin{array}{l}\text { Pocahontas No. } 1 \text { coal bed } \\
\text { Landgraff sandstone }\end{array}$ \\
\hline & & Landgraff coal bed \\
\hline & & Keystone sandstone \\
\hline & & $\begin{array}{l}\text { Keystone coal bed } \\
\text { North Fork shale } \\
\text { Simmons coal bed } \\
\text { Squire Jim coal bed }\end{array}$ \\
\hline $\begin{array}{l}\text { Upper } \\
\text { sissippian }\end{array}$ & & Bluestone Formation (part) \\
\hline
\end{tabular}

Figure 29. Stratigraphic nomenclature of the Lower Pennsylvanian Pocahontas Formation in southern West Virginia (Hennen, 1915, 1919; Krebs, 1916; Reger, 1926; Price, 1939) and southwestern Virginia (Englund, 1979; Nolde, 1994a, 1994b) (adopted from USGS, 2000). 
The Pocahontas No. 3 coal seam is set as a standard for metallurgical coal due to typically being a high-rank, low-ash, low-sulfur, and low-volatile bituminous coal (McColloch, 1995). As well, the Pocahontas No. 3 coal seam is attributed as the thickest and most persistent coal seam with high calorific value.

The western part of the Valley and Ridge physiographic province where the Pocahontas No. 3 coal seam belongs is characterized by folded and faulted thrust belts that cause steep-sided mountain ridges and valleys that follow a northeast trend. Van Dyke et al. (2018) states that the roof typically consisted of sandstone, siltstone, fireclay, and coal, and the floor consisted of sequences of $0.3 \mathrm{~m}$

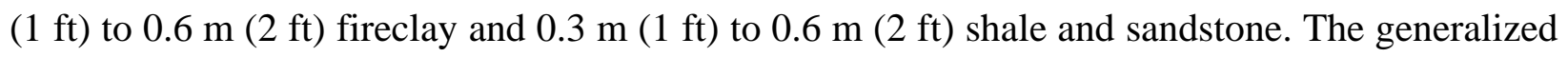
stratigraphic column is shown in Figure 30.

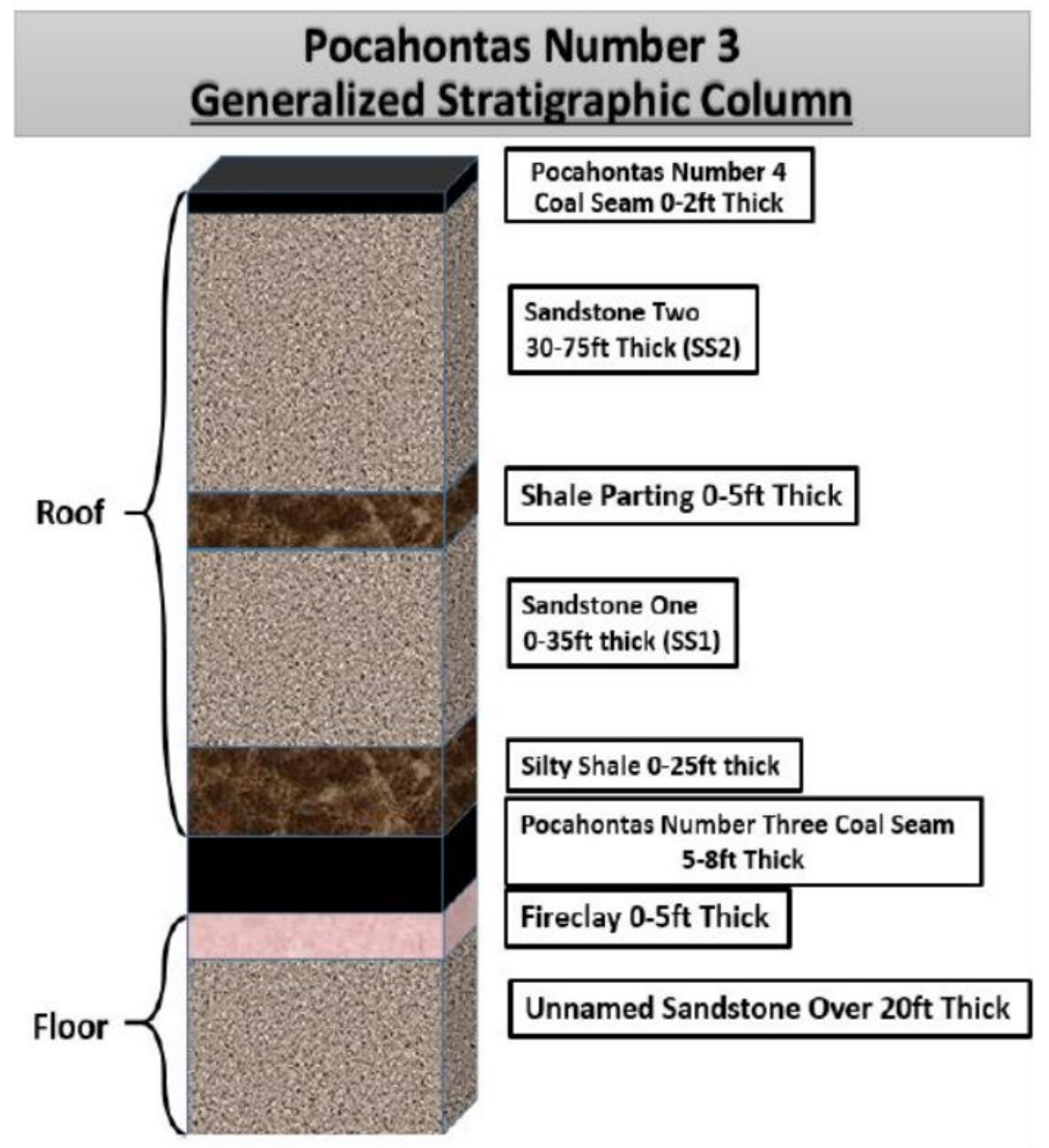

Figure 30. Generalized stratigraphic column of the Pocahontas Number 3 coal seam for floor heave in the case study mine (Adopted from Van Dyke et al., 2018). 


\subsubsection{Local Geomechanical Properties}

Van Dyke et al. (2018) stated that the geology in the studied area of the mine did not follow the typical geology in the generalized stratigraphic column (Figure 30). The geology of roof and floor significantly alters from mains adjacent to panel 25 through panel 28 . The roof in the studied area is qualified as competent, and a small amount of roof sag is experienced. The immediate roof consists of $2.75 \mathrm{~m}(9 \mathrm{ft})$ of massive sandstone with an underlying 0 to $3 \mathrm{~m}(9.9 \mathrm{ft})$ of silty shale. The immediate floor strata is composed of $0.15 \mathrm{~m}(0.5 \mathrm{ft})$ of shale and $0.7 \mathrm{~m}(2.3 \mathrm{ft})$ to $1.8 \mathrm{~m}(5.9$ $\mathrm{m})$ of fireclay, which is overlaid by bedded sandstones.

\subsection{Mine B}

\subsubsection{Background}

Mine B is located in Boone and Kanawha Counties, West Virginia. Mine B is in the Central Appalachian Region. Mine B produces metallurgical, thermal, and stoker coals through the longwall mining method.

The mine plan consists of panels with various sizes. The predominant panel size, located in the middle of two floor heave areas, is $3505 \mathrm{~m}(11,500 \mathrm{ft})$ in length and $305 \mathrm{~m}(1,000 \mathrm{ft})$ in width. A

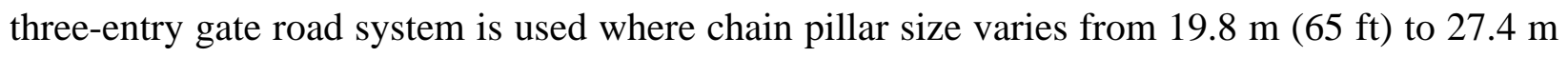
(90 ft). Overburden depth varies from $183 \mathrm{~m}(600 \mathrm{ft})$ to $365.8 \mathrm{~m}(1,200 \mathrm{ft})$.

\subsubsection{Regional Geologic Setting}

Mine B extracts the Eagle seam. The Eagle seam belongs to the Kanawha Formation in the Pottsville Group, which was deposited in West Virginia during the Middle Pennsylvanian Period of Paleozoic Era (WVGES, 2020). The Kanawha Formation typically consisted of $274 \mathrm{~m}$ (900 ft) of siltstone and shale and lesser amounts of sandstone (WVGES, 2020). Plass and Vogel (1973) stated that the original total reserve of the Eagle seam is 3.8 billion tonnes (4.2 billion tons). 


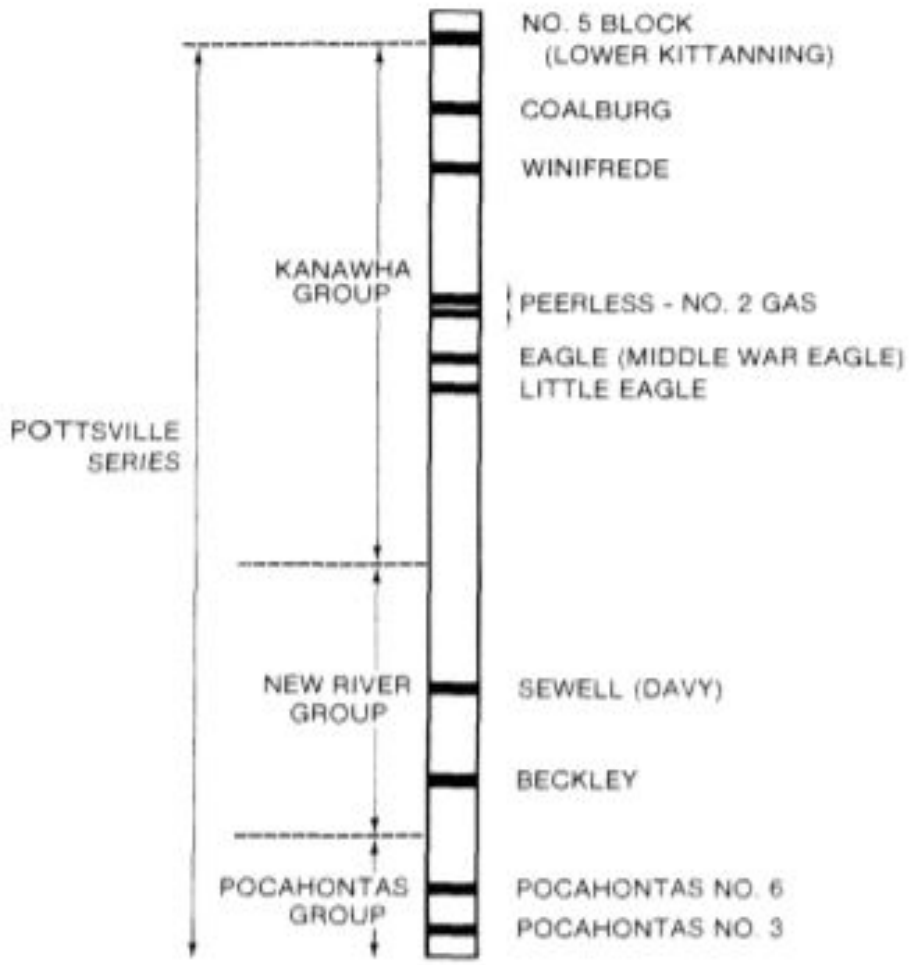

Figure 31. Stratigraphic column, showing the Eagle seam in Kanawha Group (Plass and Vogel, 1973).

\subsubsection{Local Geomechanical Properties}

Floor failure is observed in two different parts of the mine. In the first floor heave area, the floor strata consisted of dark gray fireclay and gray sandstone, underlain by shale and sandstone. In the second floor heave area, the floor strata consisted of $1.1 \mathrm{~m}(3.4 \mathrm{ft})$ to $4.2 \mathrm{~m}(13.7 \mathrm{ft})$ of shale, sandy shale, and fireclay, underlain by 0 to $3.7 \mathrm{~m}(12.1 \mathrm{ft})$ of sandstone. The roof consisted of $0.5 \mathrm{~m}(1.8$ $\mathrm{ft})$ to $3.8 \mathrm{~m}(12.4 \mathrm{ft})$ of shale, overlain by 0 to $4 \mathrm{~m}(13.2 \mathrm{ft})$ of sandstone.

\subsection{Mine C}

\subsubsection{Background}

Mine C is located in Raleigh County, West Virginia. The mine operates in the Pocahontas No. 3 coal bed and extracts bituminous coal by room and pillar mining method. According to the Mine Safety and Health Administration (MSHA) data retrieval system (MSHA, 2020), Mine C produced 
783 thousand tonnes (863 thousand tons) and 854 thousand tonnes (941 thousand tons) of bituminous coal in 2018 and 2019, respectively.

The depth of cover throughout the study area ranges from $275 \mathrm{~m}(820 \mathrm{ft})$ to $300 \mathrm{~m}(984 \mathrm{ft})$. Ribto-rib coal pillar sizes are either approximately $18 \mathrm{~m}$ x $18 \mathrm{~m}$ (59 ft x $59 \mathrm{ft}$ ) or $14.5 \mathrm{~m} \times 24.5 \mathrm{~m}$ $(47.6 \mathrm{ft} \times 80.4 \mathrm{ft})$. Entries are about $5.2 \mathrm{~m}(17.1 \mathrm{ft})$ wide. Figure 32 shows the Mine C layout at the area affected by floor heave.

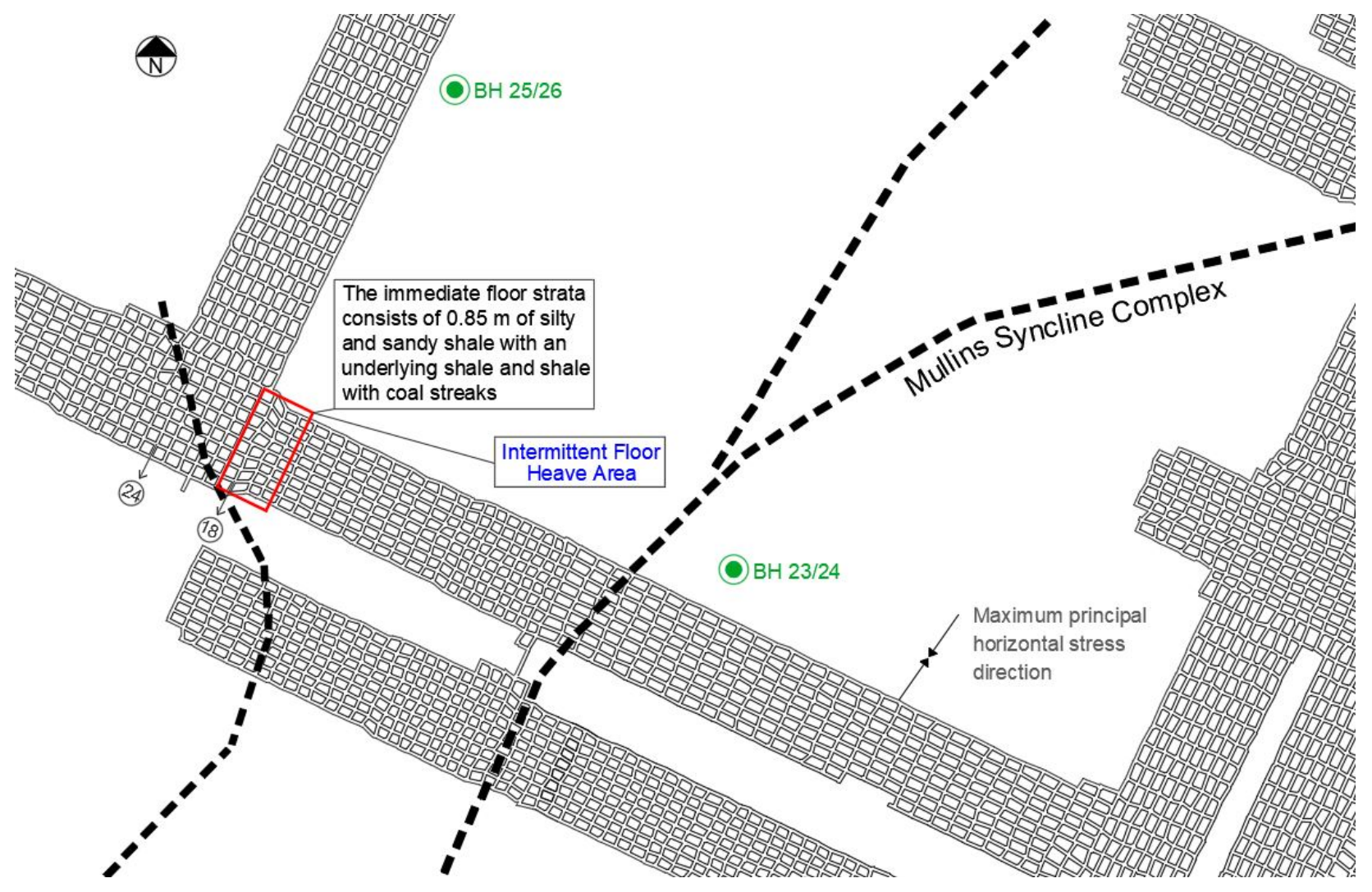

Figure 32. Mine C layout at floor heave area.

\subsubsection{Regional Geologic Setting}

Mine A and Mine C operated in the Pocahontas No. 3 coal seam. Regional geologic setting for Mine A as described in Section 3.2.2 is also valid for the regional setting of Mine C. 


\subsubsection{Local Geomechanical Properties}

According to confidential mine reports, the floor lithology from the beginning of crosscut 18 is consisted of sandy and rooted mudstone with poor bedding and sporadic clay lenses, resulting in slickensided fracturing. Abundant fossilized rootlet structures in the floor rock can be seen in Figure 33b. No significant change in floor lithology is observed until crosscut 24. Following crosscut 24, floor rock is transitioned to clay-rich mudstone with a soft, hackly texture and waxy appearance (Figure 33a).

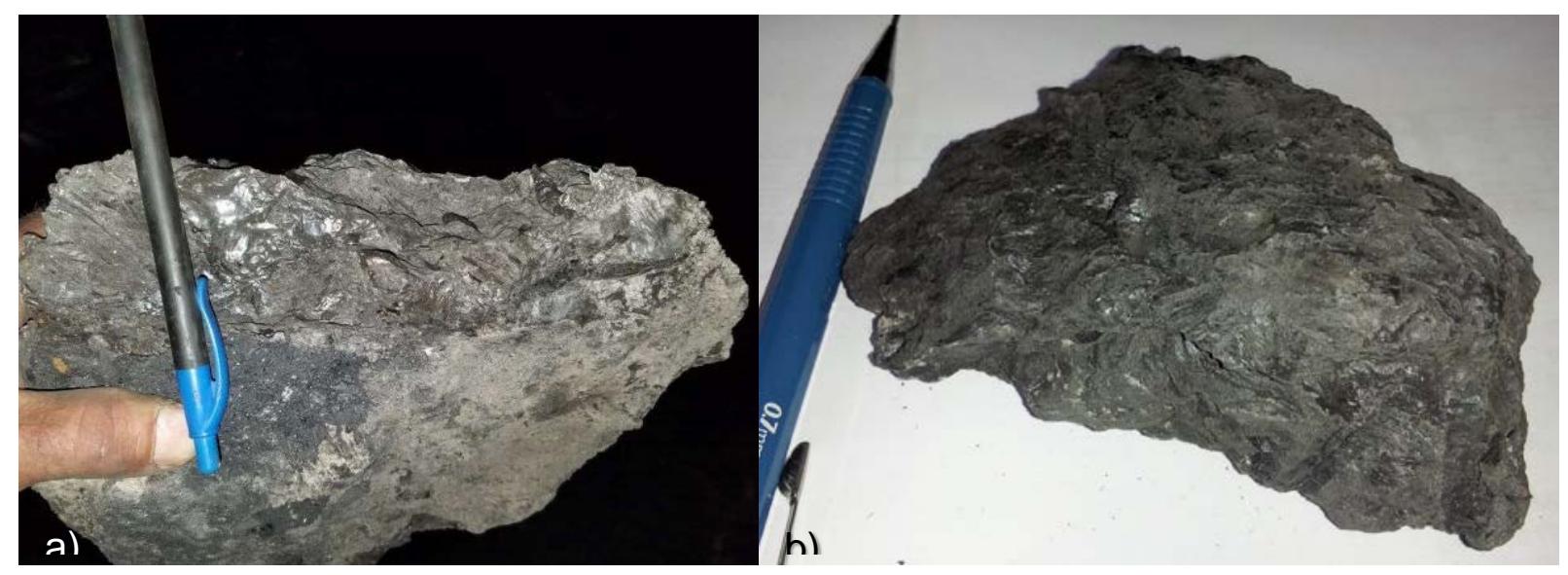

Figure 33. Floor rock samples at Mine C: a) Slickensided and rooted mudstone, b) Slickensided and rooted fireclay.

The mild bedding disruption is observed in geologic drill logs of the immediate floor. The lower Pocahontas No. 2B coal seam has not been mined and is separated from the Pocahontas No. 3 coal seam by $0.3 \mathrm{~m}(1 \mathrm{ft})-0.4 \mathrm{~m}(1.3 \mathrm{ft})$ of shale and sandy shale. The Pocahontas No.3 seam is underlain by the Pocahontas No. 2B coal seam with seam thickness ranging from $0.4 \mathrm{~m}(1.2 \mathrm{ft})$ to $0.5 \mathrm{~m}(1.7 \mathrm{ft})$ in the study area. The decrease in interval between the Pocahontas No. 3 and Pocahontas No. 2B coal seams is observed in the study area as compared to other parts of the mine. The immediate roof consisted of dark and black shale. Sandstone and sandstone with shale streaks were located above the immediate shale roof. 


\subsection{Mine D}

\subsubsection{Background}

Mine D is located in Taylor County, West Virginia. Mine D exploits the Middle Kittanning coal seam using underground longwall mining methods. According to the Mine Safety and Health Administration (MSHA) data retrieval system (MSHA, 2020), Mine A produced about 3.12 million tonnes ( 3.44 million tons) and 3.87 million tonnes ( 4.27 million tons) of bituminous coal in 2018 and 2019, respectively.

The depth of cover ranges from $150 \mathrm{~m}$ (492 ft) to $245 \mathrm{~m}$ (803.8 ft), and typical depth is approximately $180 \mathrm{~m}$ (590.6 ft). The mining height is about $2.1 \mathrm{~m}(6.9 \mathrm{ft})$. The entry height ranges from $2.1 \mathrm{~m}$ (6.9 ft) to $2.3 \mathrm{~m}$ (7.5 ft). The longwall panels are about $365 \mathrm{~m}$ (1,197.5 ft) in width and range from 1,500 m (4,921.3 ft) to 2,200 m (7,217.8 ft) in length. A three-entry gateroad system has approximately $30 \mathrm{~m}$ (98.4 ft) center-to-center chain pillars with an approximate entry width of

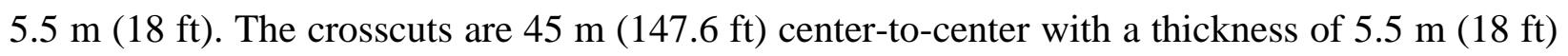
width. Figure 34 illustrates geometry of Mine D. Figure 35 shows the panel outline of Mine D in the vicinity of the study area along with floor heave location and borehole location.

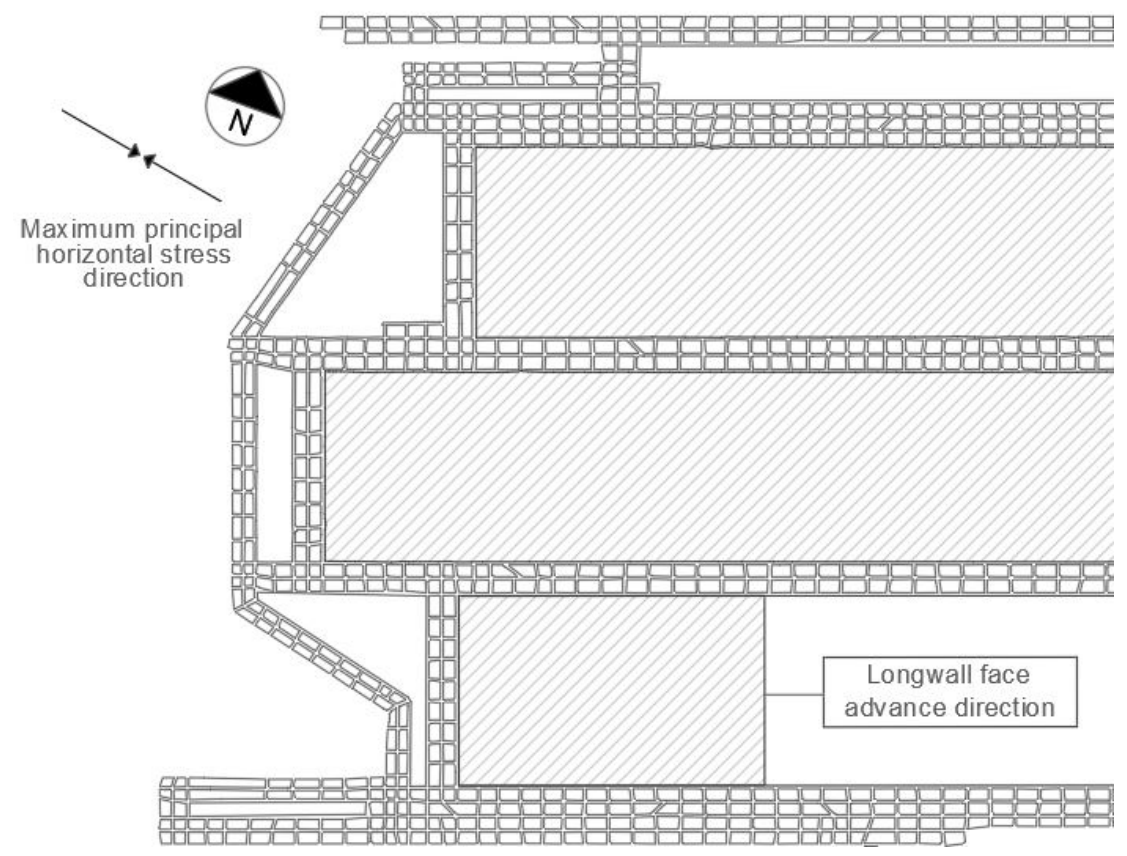

Figure 34. Mine D mine layout showing three-entry gateroad system. 


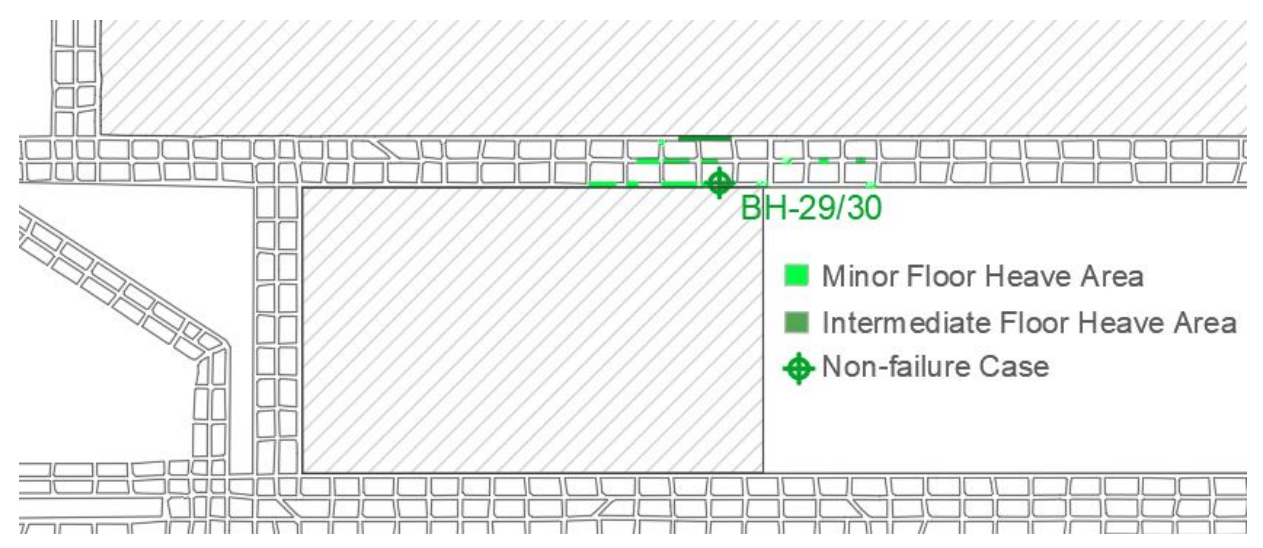

Figure 35. Mine D Floor Heave Area.

\subsubsection{Regional Geologic Setting}

Mine D lies in the Northern Appalachian Basin. Based on the geologic conditions gathered from exploratory drill core data, Mine D represents typical geologic characteristics of the Allegheny Formation. The Allegheny Group involves the Kittanning Formation along with the Freeport and Clarion Formations which typically consist of interbedded shale, sandstone, clay, and coal. The Kittanning Formation is further classified into the upper, middle, and lower Kittanning Formations. The Mined D is operated in the Middle Kittanning coal seam.

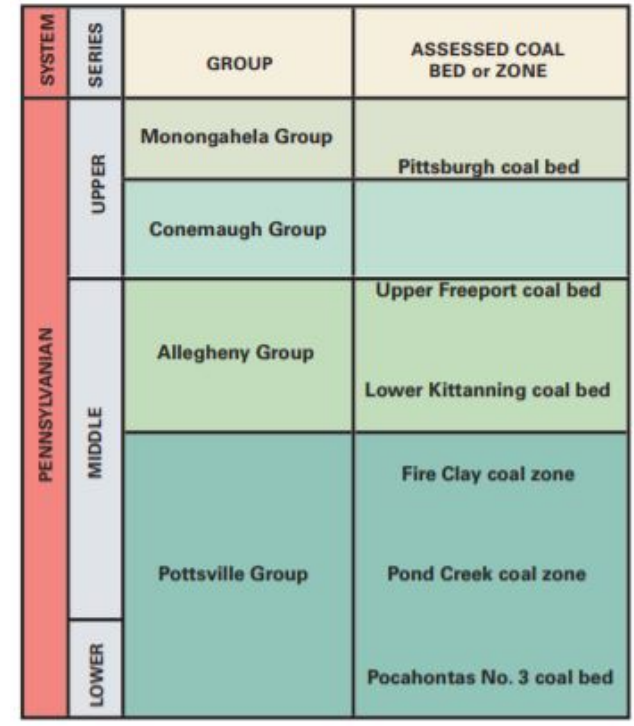

Figure 36. Generalized stratigraphic column, showing the groups and related coal beds (adopted from Ruppert et al., 2000). 


\subsubsection{Local Geomechanical Properties}

The immediate roof rocks overlying the Middle Kittanning coal seam include dark gray to carbonaceous clay shale. The immediate roof rocks grade upward to clay shale, gray sandy shale, dark gray sandy shale, or gray sandstone. Grain size and sand content differ for the gray sandy silt shale and dark gray sandy silt shale beds depending on their proximity to the laterally correlative gray sandstone beds. Grain size and sand content will increase if the distance from the correlative sandstone beds decreases. The sandy immediate roof rock overlain by the Johnstown limestone with varying purity and alternating sandstone and shale beds up to surface with varying sandstone thickness ranges from $9 \mathrm{~m}(29.5 \mathrm{ft})$ to $18 \mathrm{~m}$ (59.1 ft). Most of the rocks are attributed to be highly moisture sensitive.

The first $4.6 \mathrm{~m}(15.1 \mathrm{ft})$ of the immediate floor mostly consists of shale. The immediate shale floor overlies a heavily fractured black shale and a large light gray green shale with a total thickness of $5.5 \mathrm{~m}$ (18 ft). The average water content of all sample rocks are reported as between $0.03 \%$ and $1.4 \%$.

\subsection{Summary of Database}

The information presented in this chapter was mostly gathered through site investigations at 4 Eastern U.S. coal mines. The general properties of case studies including location, coal seam, in situ stress region, mining method, and depth of cover are summarized in Table 5. Each of the case studies differs from one other by their gateroad layouts, geologic settings, and stress conditions. The common features among the case study mines are their major principal stress (horizontal stress) and failure mechanism (buckling).

Table 5. Summary of case study mines.

\begin{tabular}{ccccccc}
\hline $\begin{array}{c}\text { Mine } \\
\text { Name }\end{array}$ & State & $\begin{array}{c}\text { Coal } \\
\text { Seam }\end{array}$ & $\begin{array}{c}\text { In situ Stress } \\
\text { Region }\end{array}$ & $\begin{array}{c}\text { Mining } \\
\text { Method }\end{array}$ & $\begin{array}{c}\text { Depth of } \\
\text { Cover m (ft) }\end{array}$ & $\begin{array}{c}\text { Major } \\
\text { Principal } \\
\text { Stress }\end{array}$ \\
\hline \multirow{2}{*}{ A } & VA & $\begin{array}{c}\text { Pocahontas } \\
\text { No. } 3\end{array}$ & $\begin{array}{c}\text { Central } \\
\text { Appalachian }\end{array}$ & Longwall & $\begin{array}{c}425-670 \\
(1394-2198)\end{array}$ & Horizontal \\
\hline
\end{tabular}




\begin{tabular}{|c|c|c|c|c|c|c|}
\hline B & WV & Eagle & $\begin{array}{c}\text { Central } \\
\text { Appalachian }\end{array}$ & Longwall & $\begin{array}{c}183-365.8 \\
(600-1200)\end{array}$ & Horizontal \\
\hline $\mathrm{C}$ & WV & $\begin{array}{c}\text { Pocahontas } \\
\text { No. } 3\end{array}$ & $\begin{array}{c}\text { Central } \\
\text { Appalachian }\end{array}$ & $\begin{array}{c}\text { Room \& } \\
\text { Pillar }\end{array}$ & $\begin{array}{c}275-300 \\
(902-984)\end{array}$ & Horizontal \\
\hline D & WV & $\begin{array}{c}\text { Lower } \\
\text { Kittanning }\end{array}$ & $\begin{array}{c}\text { Northern } \\
\text { Appalachian }\end{array}$ & Longwall & $\begin{array}{c}150-245 \\
(492-804)\end{array}$ & Horizontal \\
\hline
\end{tabular}




\section{Chapter 4 Analysis of Eastern U.S. Database}

\subsection{Introduction}

This chapter details the assessment of the applicability of the CMFR methodology proposed by Mo (2019) to the U.S. database, as well as proposed modifications to the methodology to adopt this classification system to Eastern U.S. mines. The CMFR methodology is tested on 28 geologic drill core logs from 4 case study mines in order to systematically confirm the applicability of the CMFR system on the Eastern U.S. coal mines summarized in Chapter 3. Further, modifications on the CMFR methodology are presented, particularly CMFR and the HSR calculation procedures in order to adopt the CMFR system to Eastern U.S. mines.

\subsection{Application of the CMFR to the Eastern U.S. Case Histories}

As detailed in Section 2.6, the CMFR calculation procedure consists of three main steps:

(i) The Coal Mine Floor Rating (CMFR) calculation

(ii) The Horizontal Stress Rating (HSR) calculation

(iii) The Floor Heave Index plotting

The following sections document the calculation procedure of CMFR, HSR, and plotting FHI for the case study mines.

\subsubsection{The CMFR Calculation}

CMFR is designed to represent the competency of floor strata based on geomechanical and lithological properties of immediate floor rocks. First, CMFR divides the floor strata into different floor units based on the geological differences and calculates a unit rating for each division. The uniaxial compressive strength of intact rock and discontinuity characteristics, more specifically the average discontinuity spacing of beddings and other discontinuities, are the main parameters used in the computation of unit ratings. Then, the thickness-weighted average of unit ratings is calculated. Since the configuration of the strong unit in floor strata also affects the overall behavior of the floor, the effect of the strong unit is integrated into the CMFR value using the strong unit adjustment (SUA) calculation. 
Calculation of CMFR is limited to $3 \mathrm{~m}$ (10 ft) into the floor from the coal seam, as this is the immediate concern for the stability of floor strata. The detailed exploratory geologic core log reports, which provide geo-physical borehole information, are collected from the mines and confidential consultant reports. In addition to essential geo-physics such as lithological description and characteristics, available geologic core log pictures and UCS tests are also gathered for each case study mine. In the absence of the UCS value for a particular floor unit, the UCS values are assigned using the common rock strength database in coal mines as published by Molinda and Mark (1996). The details are given in Appendix A (Table A.1).

Discontinuities in rock masses exist in a variety of sets, orientations, levels of persistence, lengths, and thicknesses. In the CMFR methodology, discontinuity spacing refers to the average distance between discontinuities; it is calculated for each individual floor unit by dividing the total number of discontinuities within a floor unit to the length of the examined floor unit. Although Discontinuity Spacing Rating in the CMFR system considers different types of discontinuities, such as joints, faults, and bedding planes, it only counts the discontinuities which are parallel or sub-parallel to the loading axis. In order words, discontinuities which are vertical or sub-vertical to the loading axis are disregarded during the assessment of discontinuity spacing in the CMFR methodology. Contrary to the CMRR system, discontinuity conditions such as cohesion and roughness are excluded in discontinuity assessments due to difficulty of sample collection and testing.

Discontinuities can also be measured using 1-dimensional, 2-dimensional, and 3-dimensional methods, i.e. linear, areal, and volumetric discontinuity spacing frequency. For the discontinuity spacing assessment in the CMFR methodology, discontinuities are expressed in 1-dimension. For 1-dimensional discontinuity spacing calculations, discontinuities are counted using drill core log pictures. Further, discontinuity spacing can be expressed with different levels of precision, ranging from a microscopic scale for laboratory samples to bigger samples for field examinations. For Discontinuity Spacing Rating calculations, discontinuities are roughly counted on the drill logs rather than meticulously counted with high laboratory-scale precision. For instance, the breaks in the core logs and unbroken beddings with a significant color change from its host rock are counted as a discontinuity. It should be noted that the mechanical breaks in the core logs towards the core 
box sides are not counted as discontinuity, since drill logs samples are more likely to be cut by geologists or drillers in order to fit the sample into the core box.

Although Terzaghi (1965), Priest and Hudson (1981), and Priest (1985) suggested how to suppress the bias on discontinuity spacing assessment on rock masses, a widely accepted discontinuity spacing assessment procedure has not yet been proposed. The issues associated with discontinuity spacing measurement have been previously encountered, as they are completely dependent on the judgement of the practitioners. However, it is found out that there will be less concern associated with the judgement of practitioners as long as a consistent method of counting discontinuity spacing is applied for all cases. Figure 37a and Figure 37b illustrate discontinuity counting for discontinuity spacing calculation for BH-9 and BH-12 at Mine A, and can set an example for future applications of the CMFR system.
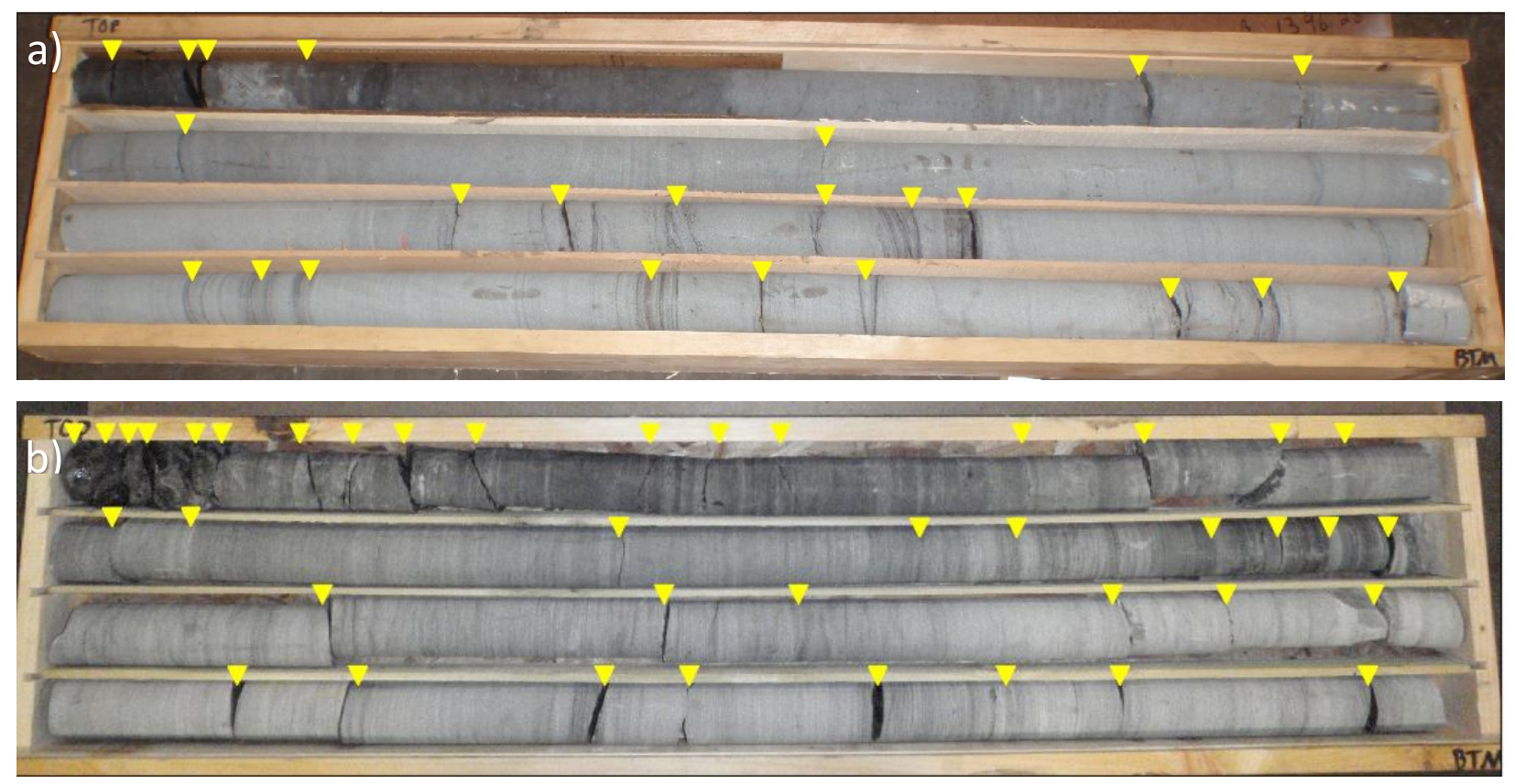

Figure 37. Discontinuity Counting on Drill Log Samples for a) BH-9, and b) BH-12.

After calculating the thickness-weighted average of Unit Ratings through UCS Rating and Discontinuity Spacing Rating, the final step for CMFR computation is examining the need for the Strong Unit Adjustment. The SUA is required if a strong unit is laid between two relatively weak units in the immediate floor strata. It is noteworthy that the weak and strong units are decided 
based on Unit Rating rather than the Uniaxial Compressive Strength (UCS) of floor units. In order to apply the SUA, the following requirements are tested for case studies (Mo, 2019):

(i) Presence of the strongest unit within $1 \mathrm{~m}(3.3 \mathrm{ft})$ of floor strata

(ii) Minimum thickness of $0.7 \mathrm{~m}(2.3 \mathrm{ft})$ for the strongest unit

(iii) Minimum Strong Unit Difference (SUD) of 20 between Unit Rating of the strongest layer and thickness-weighted average of Unit Ratings

The SUA is not applied to any of the case studies since the SUA requirements listed above are not fulfilled. Therefore, the thickness-weighted average of Unit Ratings is expressed as the final CMFRs. The details of CMFR are given in Appendix A (Table A.2).

\subsubsection{The Horizontal Stress Rating Calculation}

The second step of the CMFR methodology is the Horizontal Stress Rating (HSR) calculation. As explained in Section 2.6.1.4, HSR is the summation of Depth Rating and Angle Rating (Table 4) (Mo, 2019). Mine maps in AutoCAD are collected for each case study mine. Mine maps contain borehole locations, overburden contour lines, and major principal stress direction, which is horizontal stress for these case study mines. The depth of cover for each core log location is obtained using overburden contour lines. Similarly, the angles between major principal horizontal stresses and entries where the core log is located are measured. Table 6 summarizes the depth of cover, angle between entries, and major principal horizontal stress along with the corresponding HSR ratings.

Table 6. Horizontal Stress Rating calculation.

\begin{tabular}{|c|c|c|c|c|c|c|c|}
\hline $\begin{array}{l}\text { Mine } \\
\text { Name }\end{array}$ & $\begin{array}{c}\text { Borehole } \\
\text { Name }\end{array}$ & $\begin{array}{c}\text { Failure or } \\
\text { Non-failure }\end{array}$ & $\begin{array}{c}\text { Depth of } \\
\text { Cover m (ft) }\end{array}$ & $\begin{array}{c}\text { Depth } \\
\text { of } \\
\text { Cover } \\
\text { Rating }\end{array}$ & $\begin{array}{c}\text { Angle } \\
\left({ }^{\circ}\right)\end{array}$ & $\begin{array}{c}\text { Angle } \\
\text { Rating }\end{array}$ & $\begin{array}{c}\text { Horizontal } \\
\text { Stress } \\
\text { Rating }\end{array}$ \\
\hline $\mathrm{A}$ & BH 1 & Failure & 670 (2198.2) & 67 & 90 & 5 & 72 \\
\hline A & BH 2 & Failure & 600 (1968.5) & 60 & 90 & 5 & 65 \\
\hline A & BH 3 & Failure & 715 (2345.8) & 71.5 & 90 & 5 & 76.5 \\
\hline A & BH 4 & Non-failure & 670 (2198.2) & 67 & 0 & 0 & 67 \\
\hline
\end{tabular}




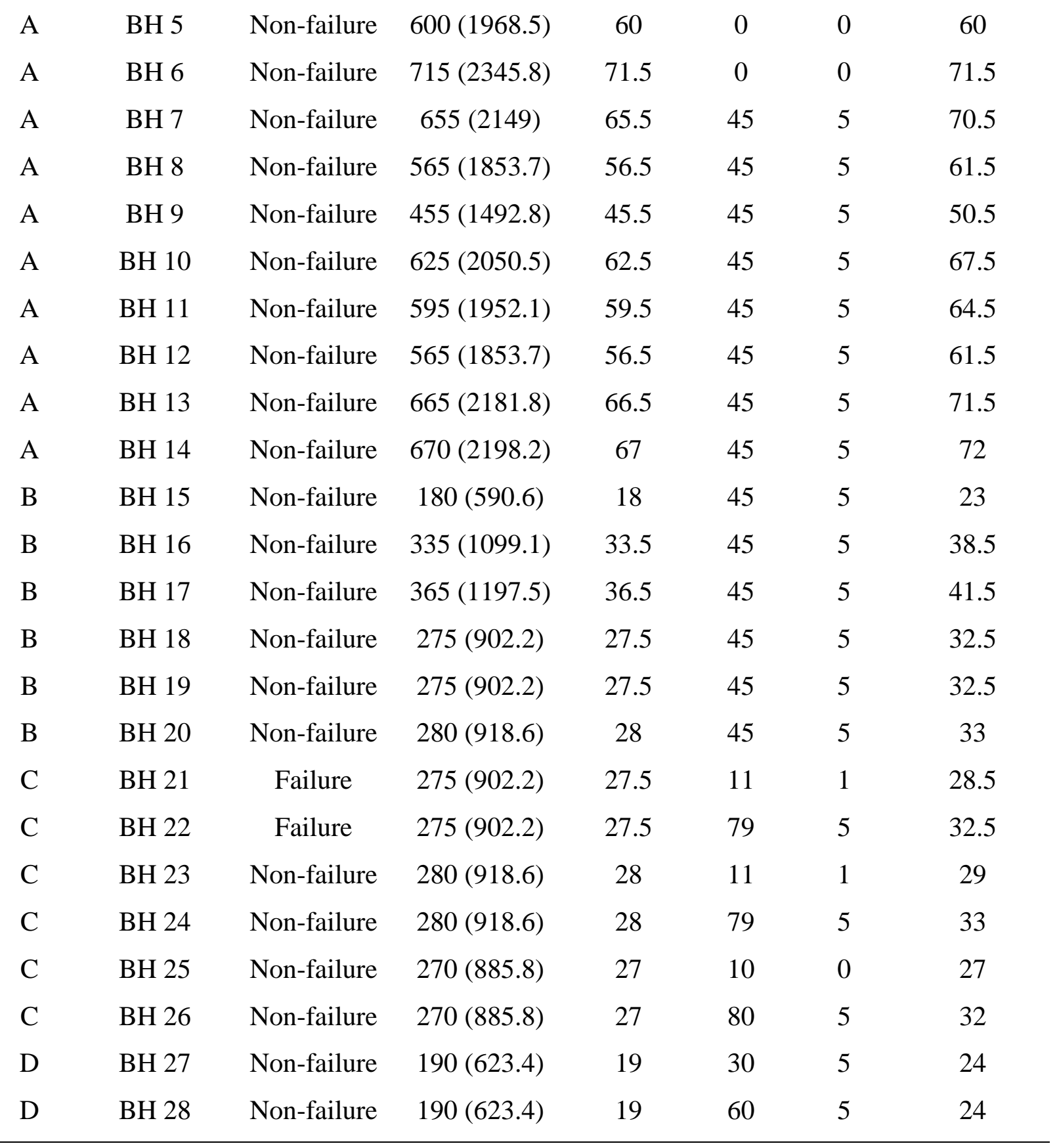

\subsubsection{The Floor Heave Index}

The Floor Heave Index (FHI) graphically compares failure and non-failure cases. The FHI aims to combine the effect of rock mass quality and operational conditions and further correlates them with the stability of the floor strata. The FHI is plotted for 32 geologic core logs from 4 case study 
mines using CMFR and the Horizontal Stress Rating (HSR) (Figure 38). The input parameters for CMFR and HSR are in metric units.

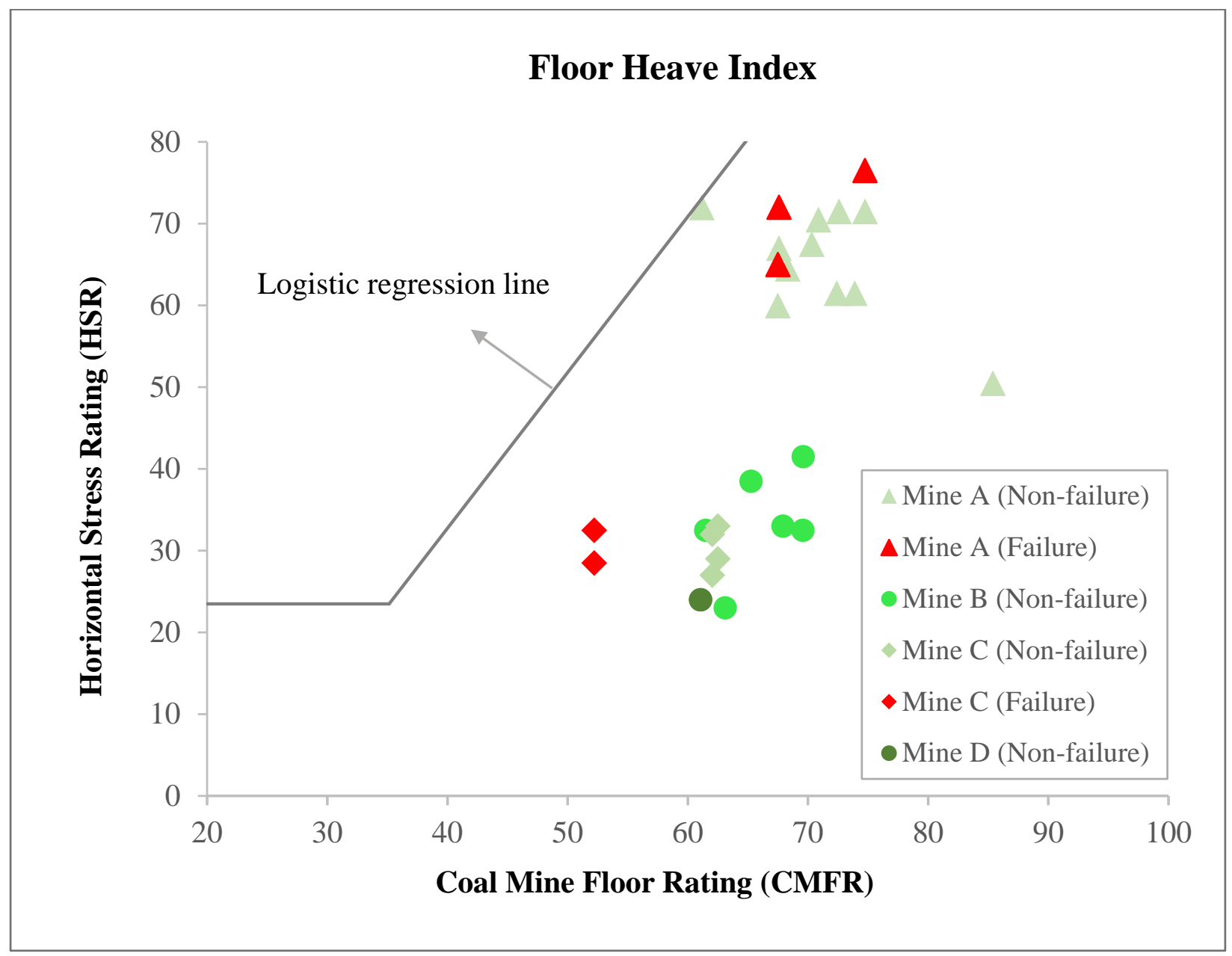

Figure 38. The Floor Heave Index.

\subsection{Modifications on the CMFR Methodology}

Figure 38 shows that the FHI could not accurately separate failure and non-failure cases from one another for the case study mines in the Eastern U.S. database. This is not an unexpected result, as the linear regression line in FHI is developed based on a database involving case studies in 
Australia with geological, geomechanical, and operational properties, and it can only be used within the limits of its database.

Since the application of the CMFR methodology as proposed by Mo (2019) to the cases outside of its database in the Eastern U.S. does not provide a meaningful coal mine floor stability assessment, modifications on CMFR and HSR are made to adopt the CMFR methodology to the Eastern U.S. underground coal mines.

\subsubsection{Modifications for CMFR}

In this section, the CMFR calculation procedure and associated assumptions are revisited, and small changes and recommendations are made to close the current performance gaps. The weightings of the UCS Rating and Discontinuity Rating of CMFR do not change and are used in its original form. In other words, it is accepted that 35\% of CMFR is generated by the Discontinuity Spacing Rating and 65\% of it is formed by the UCS Rating.

Mo (2019) made two suggestions specific to the floor units with UCS less than 10 MPa (1,450 psi), which create inconsistent CMFR calculation procedure. First, according to CMFR rating for UCS (Table 1), UCS Rating of 10 is suggested to assign to floor units with UCS less than $10 \mathrm{MPa}$ (1,450 psi). Second, he suggested applying a Unit Rating of 40 to the floor units with UCS of less than $10 \mathrm{MPa}(1,450 \mathrm{psi})$ regardless of the discontinuity spacing. It is realized that there are two different scenarios for Unit Rating calculation of the floor units with UCS less than 10 MPa (1,450 psi). Therefore, these assumptions are reviewed and a single Unit Rating calculation procedure for the floor units with UCS less than $10 \mathrm{MPa}(1,450 \mathrm{psi})$ is introduced.

Table 7. Unit Rating examples for floor layers with UCS greater than $40 \mathrm{MPa}$.

\begin{tabular}{ccccccc}
\hline Mine & Floor & UCS & UCS & Discontinuity & Discontinuity & Unit \\
Name & Lithology & (MPa) & Rating & Spacing (mm) & Spacing Rating & Rating \\
\hline A & Black shale & 44 & 44 & 18 & 0 & 44 \\
A & Sandy fireclay & 43 & 44 & 52 & 5 & 49 \\
\hline
\end{tabular}


According to Table 1, the weakest rock category based on the UCS of rocks is the ones with UCS less than $10 \mathrm{MPa}(1,450 \mathrm{psi})$. It is hypothesized that Mo’s second assumption which assigns a Unit Rating of 40 to the floor unit in the weakest rock category tends to be conservative to reflect the effect of weak immediate floor on CMFR. In other words, a Unit Rating of 40 overestimates the contribution of the weak floor rock in CMFR. In order to investigate this hypothesis, floor units which have a Unit Rating of 40 or close to 40 in the database are gathered together and summarized in Table 7. Two floor unit examples in the database demonstrate that a Unit Rating of 40 represents the floor units with UCS of $43 \mathrm{MPa}(6236,6 \mathrm{psi})$ and $44 \mathrm{MPa}(6,382 \mathrm{psi})$. On the other hand, Mo (2019) designated a Unit Rating of 40 for the weakest rock category with UCS less than $10 \mathrm{MPa}$. This comparison supports the hypothesis that Unit Rating of 40 overestimates the competency of floor units with UCS less than $10 \mathrm{MPa}(1,450 \mathrm{psi})$.

Further, according Mo (2019), if a Unit Rating of 40 is assigned to the floor unit with UCS of less than $10 \mathrm{MPa}, 10$ out of 40 accounts for the UCS Rating are based on the UCS Rating Scale (Table 1), and the remaining 30 are assigned for Discontinuity Spacing Rating. Although the Discontinuity Spacing Rating of 30 does not fit an interval in the Discontinuity Spacing Rating scale (Table 2), it roughly indicates that the discontinuity spacing between $200 \mathrm{~mm}(0.66 \mathrm{ft})$ and $600 \mathrm{~mm}$ (1.97 ft) which represents a floor rock mass with widely spaced discontinuities. Based on the correlations between UCS and discontinuity spacing of geologic core logs in the database, the presence of rock units with UCS less than $10 \mathrm{MPa}(1,450 \mathrm{psi})$ and with widely spaced discontinuities are found to be unrealistic. Therefore, it is asserted that assigning a Unit Rating of 40 does not properly quantitate the quality of floor with UCS less than $10 \mathrm{MPa}(1,450 \mathrm{psi})$, and a lower Unit Rating should be assigned to floor units with UCS less than $10 \mathrm{MPa}(1,450 \mathrm{psi})$ for a more reasonable representation of floor rock quality.

Moreover, Mo (2019) suggested a minimum Unit Rating of 25 which is applicable to all cases. In comparison to above-mentioned suggestions by Mo (2019), it is found to be unrealistic to concurrently assign a Unit Rating of 40 to floor units within the weakest rock category with UCS less than $10 \mathrm{MPa}$ and apply a minimum Unit Rating of 25. It is believed that a consistent Unit Rating concept should be introduced to be assigned to the floor units with less than $10 \mathrm{MPa}(1,450$ psi) and to be set as a minimum Unit Rating. Therefore, the author claims that it is more tenable to assign the same Unit Rating to the floor units with less than $10 \mathrm{MPa}$ (1,450 psi) and apply the 
same Unit Rating as a minimum Unit Rating to all cases. Consequently, the assumption of Unit Ratings for the weak floor units of the CMFR calculation changed, and the Unit Rating for assigning the floor units with less than $10 \mathrm{MPa}(1,450 \mathrm{psi})$ decreased from 40 to 25 . The modified Unit Rating assumption for the weak floor units suggests:

(i) Applying minimum Unit Rating of 25 to all cases,

(ii) Applying Unit Rating of 25 regardless of discontinuity spacing where the UCS less than or equals $10 \mathrm{MPa}(1,450 \mathrm{psi})$,

(iii) Applying Unit Rating of 25 where floor unit is heavily broken and UCS test is not possible.

Figure 39 illustrates the variation between original and modified CMFR. Its results indicated that the modified CMFR calculation only affects 10 of the geologic core log CMFR values out of 28 . The mean of the CMFR remained the same as 66 after applying the modified CMFR calculation procedure. Further, CMFR calculated for the database with Australian case histories by Mo (2019) range from 37 to 72 while they range from 52 to 85 for the database with Eastern U.S. coal mines. Overall, the modified CMFR calculation procedure has been proposed not to entirely change the original CMFR calculation procedure, but to clarify disparities and represent the rock mass more realistically.

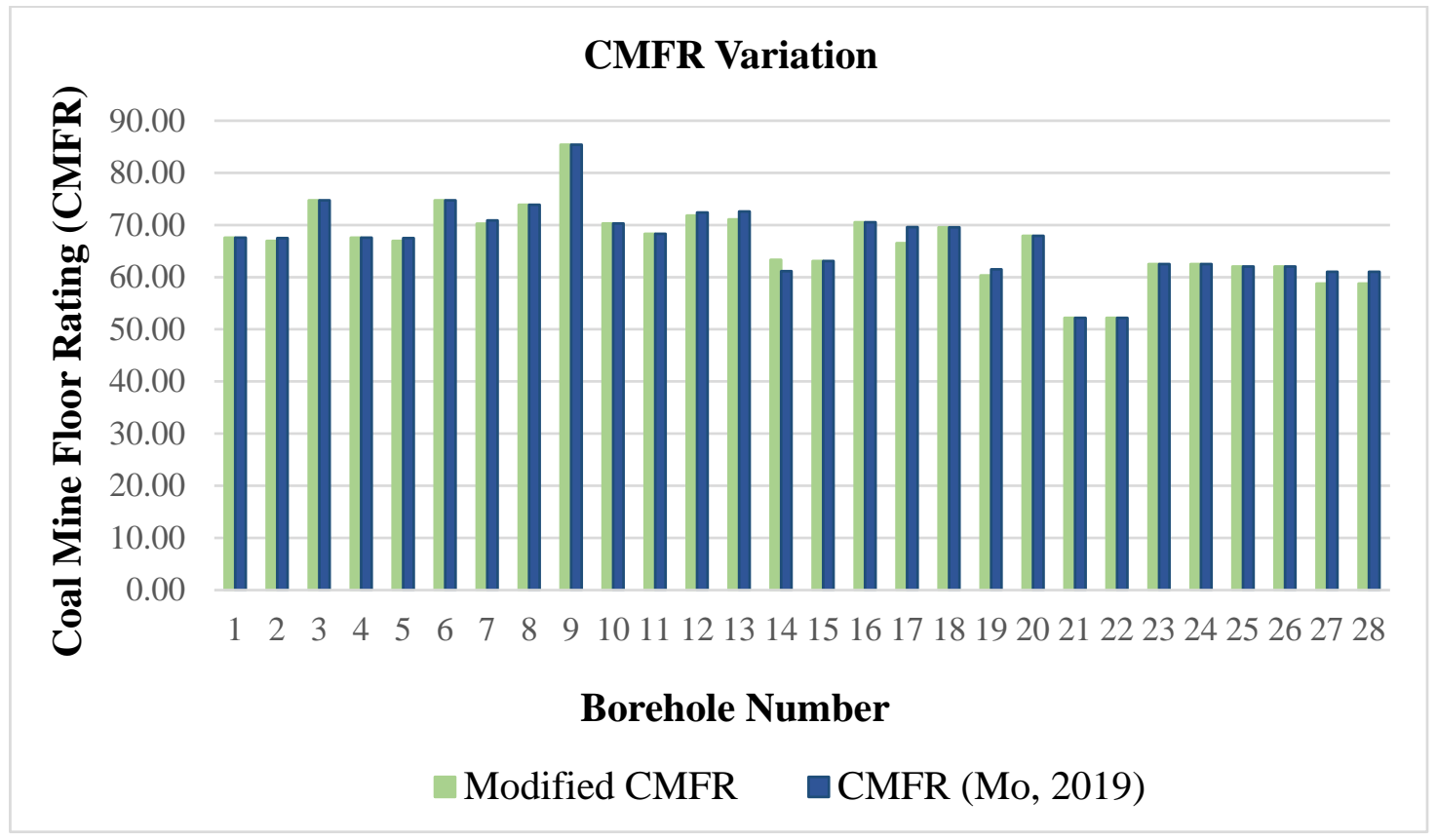

Figure 39. Variation in CMFR. 


\subsubsection{Modifications of the Horizontal Stress Rating}

The Floor Heave Index (FHI) for the case studies is presented in Figure 38, where the failure and non-failure cases are not separated from each other through the original CMFR system. Weak correlation between FHI proposed by Mo (2019) and the floor stability estimation for the U.S. cases is not an unexpected result, since Mo (2019) developed the CMFR system for Sydney and Bowen Basin coal mines in Australia. There are major differences in regional stress, geologic conditions, and operational parameters between the U.S. and Australian basins. It is hypothesized that the inaccurate classification of failure and non-failure cases for the Eastern U.S. coal mines results from calculations in the Horizontal Stress Rating (HSR). In order to examine this hypothesis, a Modified Horizontal Stress Rating (MHSR) with a more detailed scale of Angle and Depth Rating is derived for the case study mines. This chapter delves deeper into the distinct characteristics of the Eastern U.S. and Australian basins and presents the details of the MHSR.

\subsubsection{Modifications of the Depth Rating}

The Depth Rating in the HSR, proposed by Mo (2019) is the only component that reflects the stress state of the floor strata. The Depth Rating is calculated simply by dividing depth of cover (m) by 10 (Mo, 2019). Therefore, the Depth Rating represents the vertical stress state but not necessarily and directly the horizontal stress state of the rock mass. In practice, the magnitude and state of principal stresses in rock mass, including horizontal and vertical stresses, is spatially variable, mostly due to variable topography. Since horizontal stress is an important factor in the buckling type of floor failures, it is essential to adequately incorporate the effects of horizontal stress magnitude into a floor rock mass classification system. Therefore, the Depth Rating system proposed by Mo (2019) is revised and modified to incorporate the magnitude of horizontal stresses into HSR.

McGarr (1988) stated that the gravitational stress formula, which multiplies depth from the surface and the unit weight of rock, for the lithostatic stress state model for in situ stress calculation tends to ignore effects of tectonic stresses and assumes all three principal stresses are almost equal to each other. As the lithostatic stress state model cannot be used for in situ horizontal stress calculations, a thorough understanding of the horizontal stress magnitude variation should be implemented into the CMFR system for adequate floor stability estimations. Dolinar (2003) stated 
that the depth of cover cannot be considered as a remarkable factor for the increase in the horizontal stress, although the associated database of the Eastern U.S. encompasses a large range of depth of cover varying from $83.8 \mathrm{~m}(275 \mathrm{ft})$ to $762 \mathrm{~m}(2,500 \mathrm{ft})$. He stated that the horizontal stress magnitude is significantly controlled by the elastic modulus of rock in addition to the depth of cover. Guangyu et al. (1986) also found that a strong relationship exists between the elastic modulus of the rock and the horizontal stress for cases in China. Similarly, the research performed in United Kingdom coalfields also observed a high correlation between the elastic properties and the maximum horizontal stress (Cartwright, 1997).

Mark and Gadde (2008) investigated the horizontal stresses in shallow and deep cover underground mines by statistical methods using the largest database ever created for this purpose, with more than 350 stress measurements from numerous coal fields worldwide. They indicated that the highest modulus rocks are observed in the Eastern U.S. when compared to the data set including coal fields from Western U.S., UK, Germany, South Africa, India, and predominantly New South Wales and Queensland in Australia. Their findings imply that it is imperative to include the elastic modulus of rocks in horizontal stress calculations, particularly for the cases in the Eastern U.S. For this reason, the horizontal stress formula (Equation 4.1) obtained by regression analysis between depth and the modulus is used for maximum horizontal stress calculations in HSR.

$$
S_{\text {Hax }}=B_{0}+B_{1} \times \text { Depth }+B_{2} \times \text { Modulus }
$$

where $\mathrm{B}_{0}$ is one component of the excess stress with unit of $\mathrm{MPa}, \mathrm{B}_{1}$ is depth gradient with unit of $\mathrm{MPa} / \mathrm{m}, \mathrm{B}_{2}$ is modulus factor, and all are constants. Mark and Gadde (2008) conducted a regionby-region analysis and specified these constants based on the coal field locations. In this study, constants specified for the Eastern U.S. coal mines are used where $\mathrm{B}_{0}$ is $-2.1 \mathrm{MPa}$ (-298 psi), $\mathrm{B}_{1}$ is $1.64 \mathrm{MPa} / \mathrm{m}(0.037 \mathrm{psi} / \mathrm{ft})$, and $\mathrm{B}_{2}$ is $0.41 \times 10^{-3}$. In Equation 4.1 , constant $\mathrm{B}_{0}$ refers to one component of the excess stress, which is found to be independent from depth gradient. Mark and Gadde (2008) also noted that there is minor interaction between depth and modulus for non-coal data set. These results support the hypothesis that Depth Rating in HSR is not enough to represent the effect of horizontal stress in the floor stability analysis, and HSR should include additional factors to represent horizontal stress magnitude such as the elastic modulus of floor rocks. 
Therefore, it was decided to calculate maximum horizontal stress using Equation 4.1 (Mark and Gadde, 2008).

For the calculation of maximum horizontal stress applied to the floor strata, depth is primarily obtained through a collaborative use of boundary element software LaModel, Stability Mapping, and Equation 4.1 (Heasley, 1998). LaModel and Stability Mapping are included into the calculation procedure as they provide more realistic in situ stress values, including the effect of topographic relief in stress conditions. Consequently, a large-scale model is constructed through LaModel and Stability Mapping. In situ vertical stress distribution on the mine floor for Mine A is shown in Figure 40. The area shown in Figure 40 is meshed with 1,400 x 1,400 3-m (10 ft) elements in the LaModel software. The calibration method for LaModel proposed by Heasley (2009) and is used to compute lamination thickness and also coal material properties. It should be noted that the depth can be also obtained from topographic contours and substituted in Eq. 4.1 if there are not enough input parameters or time to conduct LaModel stress analysis.

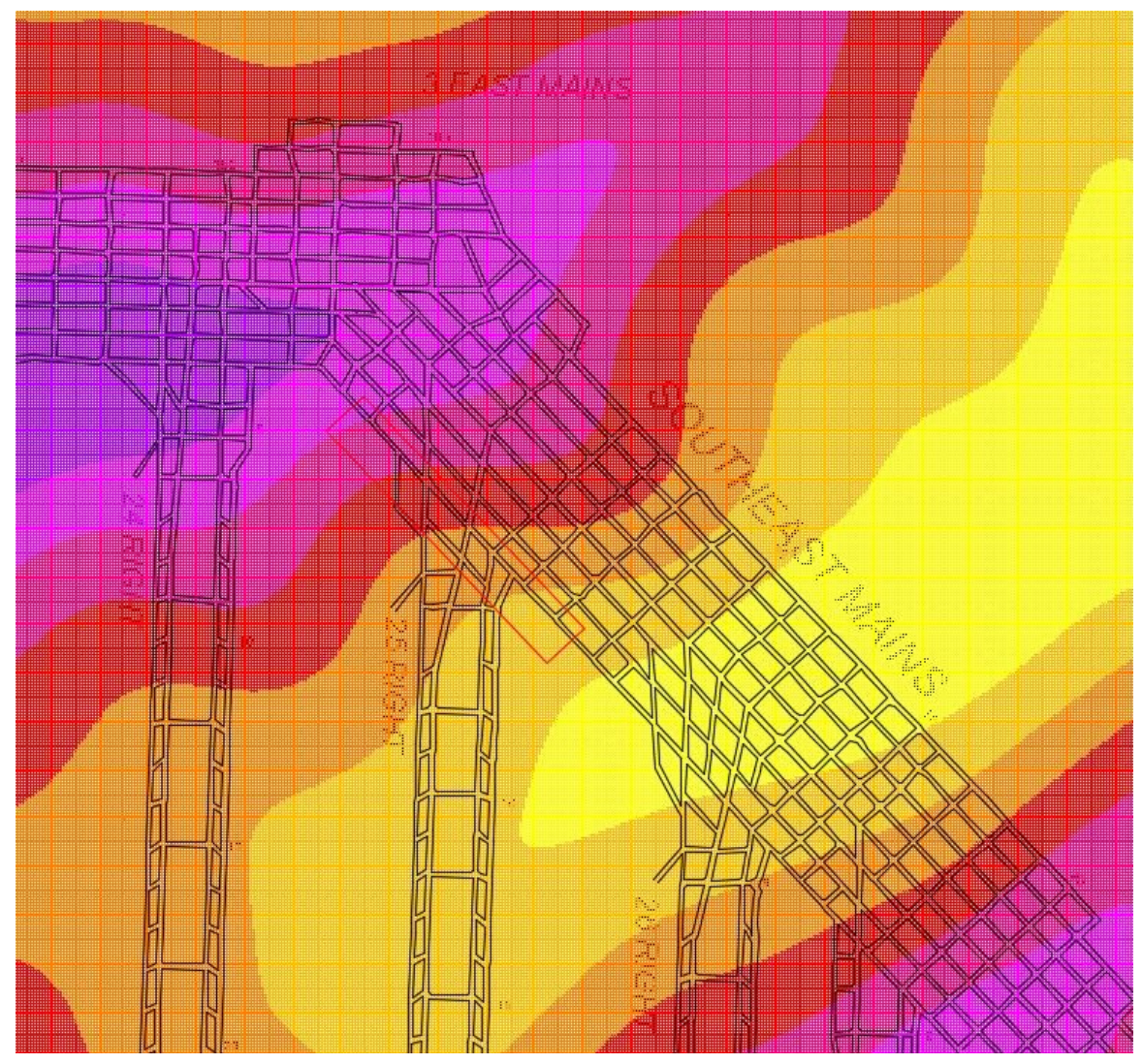

Figure 40. LaModel mesh for overburden stress in Mine A (adopted from Cicek et al., 2020) 
After obtaining in situ vertical stresses at the location of drill logs from the LaModel results, the depth for each drill log is calculated using the vertical gravitational stress formula (Equation 4.2) (Brady and Brown, 2004)

$$
z=\frac{\sigma_{\text {vertical }}}{\gamma}
$$

where $z$ is the depth below surface and $\gamma$ is the unit weight of rock or so-called vertical stress gradient. The default vertical stress gradient of $0.025 \mathrm{MPa} / \mathrm{m}(1.125 \mathrm{psi} / \mathrm{ft})$ in LamPre is utilized in Equation 4.2. For cases where the mine maps or input parameters required to build LaModel stress models were not adequate, the depth was obtained at the drill log locations using the topographic map of the mines.

Sears et al. (2018), Van Dyke et al. (2018), and Cicek et al. (2020) present detailed floor heave assessments at Mine A, and the elastic modulus of shale is stated to be a minimum of $14.01 \mathrm{GPa}$ and maximum of $17.6 \mathrm{GPa}$. However, it is found that the strong layer in the immediate floor strata at Mine A is not always shale, but sometimes sandstone. Therefore, using the elastic modulus of shale for all drill logs does not provide an appropriate representation for the floor strata at Mine A. Moreover, several of the case studies in the database do not have such a generalized elastic modulus of strong floor unit in the immediate floor strata. Therefore, a practical and consistent calculation method for elastic modulus calculation is presented. First, the elastic modulus of strong floor unit in the immediate floor strata for all drill log locations are gathered together using field data, published papers, and confidential mining reports. Then, the thickness-weighted average of the elastic modulus of stronger layers in the immediate floor strata is calculated. Afterwards, the thickness-weighted average of the elastic modulus is treated as a single elastic modulus for the mine floor and used for horizontal stress calculations of the associated mines. For cases in which the elastic modulus is not provided by case study mines, linear interpolation is conducted based on the UCS values of the strong floor unit using Table A.2, which shows the suggested elastic modulus of the rocks (Tulu et al., 2017). The details are given in Appendix A (Table A.3).

By following the depth and modulus calculation procedure and plugging them into Equation 4.1, the maximum horizontal stresses is calculated. Contrary to Depth Rating created by Mo (2019), the maximum horizontal stress has not been termed as a rating yet. Instead, the maximum 
horizontal stress will be combined with the horizontal stress orientation in the upcoming section, and then modified HSR will be proposed.

\subsubsection{Modifications of the Angle Rating}

As a continuation of section 4.3.2.1, which explains the modified depth rating calculation, this section details how to include the effect of horizontal stress orientation into the CMFR system through a continuous Angle Rating concept. The CMFR system proposes a discrete Angle Rating scale (Table 3) that assigns certain ratings for different angle intervals. The systematically increasing ratings are assigned to angle intervals between $10^{\circ}$ and $30^{\circ}$. In other words, consistently increasing Angle Ratings are given to angle intervals of $0^{\circ}-10^{\circ}, 10^{\circ}-20^{\circ}$ and $20^{\circ}-30^{\circ}$. The same maximum Angle Rating is assigned to angles greater than and equal to $30^{\circ}$.

As summarized in Table 6 , in nearly 75\% of cases in the Eastern U.S. database, the angle between the entry and major principal horizontal stress is greater than $30^{\circ}$ and is represented by the same Angle Rating of 5 according to angle rating proposed by Mo (2019), regardless of how much greater the angle is than $30^{\circ}$. In other words, the angle of $30^{\circ}$ and $90^{\circ}$ are represented by the same Angle Rating. For example, the angle between mine entry and maximum horizontal stress in Mine A is $90^{\circ}$ for failure and $0^{\circ}$ or $45^{\circ}$ for non-failure cases.

It is hypothesized that assigning Angle Rating to uneven angle intervals, and, more importantly, assigning the same Angle Rating for a large angle interval between $30^{\circ}$ and $90^{\circ}$ is likely to be the reason for the inaccurate classification of failure and non-failure cases in the Eastern U.S. database (Figure 38). Therefore, it is hypothesized that the discrete Angle Rating scale used in the Horizontal Stress Rating should be replaced with a continuous Angle Rating scale. In order to examine this hypothesis, a Modified Horizontal Stress Rating (MHSR) with a more detailed scale of angle is derived for the Eastern U.S. mines.

Calculation of a continuous Angle Rating begins with horizontal stress rotation calculations. The counterclockwise 2D stress transformation formula from continuum mechanics is implemented to the Angle Rating calculation procedure, which makes it possible to calculate the rating for every single angle value from $0^{\circ}$ to $90^{\circ}$ (Equation 4.3 and Equation 4.4). 


$$
\begin{aligned}
& \sigma_{x x}^{\prime}=\frac{1}{2}\left(\sigma_{x x}+\sigma_{y y}\right)+\frac{1}{2}\left(\sigma_{x x}-\sigma_{y y}\right) \cos (2 \theta)+\sigma_{x y} \sin (2 \theta) \\
& \sigma_{y y}^{\prime}=\frac{1}{2}\left(\sigma_{x x}+\sigma_{y y}\right)-\frac{1}{2}\left(\sigma_{x x}-\sigma_{y y}\right) \cos (2 \theta)-\sigma_{x y} \sin (2 \theta)
\end{aligned}
$$

Through Equation 4.3 and Equation 4.4, maximum principal stress $\left(\sigma_{1}, \sigma_{\mathrm{h} 1}\right)$ and minimum principal stress $\left(\sigma_{3}, \sigma_{h}\right)$ are rotated for angles between the entry and major principal horizontal stress at case study mines. In addition to rotating the principle stresses, the horizontal stresses are normalized by

dividing the minimum principal stress $\left(\sigma_{3}, \sigma_{\mathrm{h} 3}\right)$ by the maximum principal stress $\left(\sigma_{1}, \sigma_{\mathrm{h} 1}\right)$. The maximum horizontal stress to the minimum horizontal stress ratio for Mine A is stated as 1.5 by Sears et al. (2018). From the confidential consulting reports, the maximum horizontal stress to the minimum horizontal stress ratio for Mine $\mathrm{D}$ is calculated as 1.98. The ratio of the maximum horizontal stress to the minimum horizontal stress for Mine B and Mine C, which is located in the Central Appalachian basin, is decided based on an extensive study of horizontal stress and tectonic strain measurements in Eastern U.S. coal mines conducted by Dolinar (2003). The horizontal tectonic strain in the Central Appalachian basin found to be bimodal, so the horizontal tectonic strain field of the Central Appalachian basin is again grouped into high and low strain zones. The average maximum strain ratio in the Northern Appalachian region, which is 1.85 , is set to be the ratio of the maximum horizontal stress to the minimum horizontal stress for Mine B and Mine C. The coefficient calculated upon normalization is termed as the orientation coefficient and provides a value between 0 and 1, which enables an easy comparison between minimum and maximum principal stresses. By rotating and normalizing the principal stresses, the effect of horizontal stress orientation is calculated. Lastly, the previously calculated orientation coefficient and maximum horizontal stress are multiplied by one another to calculate the Modified Horizontal Stress Rating (MHSR).

The calculation steps for the Modified Horizontal Stress Rating (MHSR) can be summarized as follows:

(i) Maximum horizontal stress calculation 
(ii) Stress rotation and normalization

(iii) Orientation coefficient calculation

Figure 41 shows the variation in HSR which is calculated by original HSR (Mo, 2019) and modified HSR calculation procedure. HSR calculated for the database with Australian case histories by Mo (2019) range from 23.5 to 61 while they range from 23 to 76.5 for the database with Eastern U.S. coal mines. The modified HSR ranges from 4 to 24.

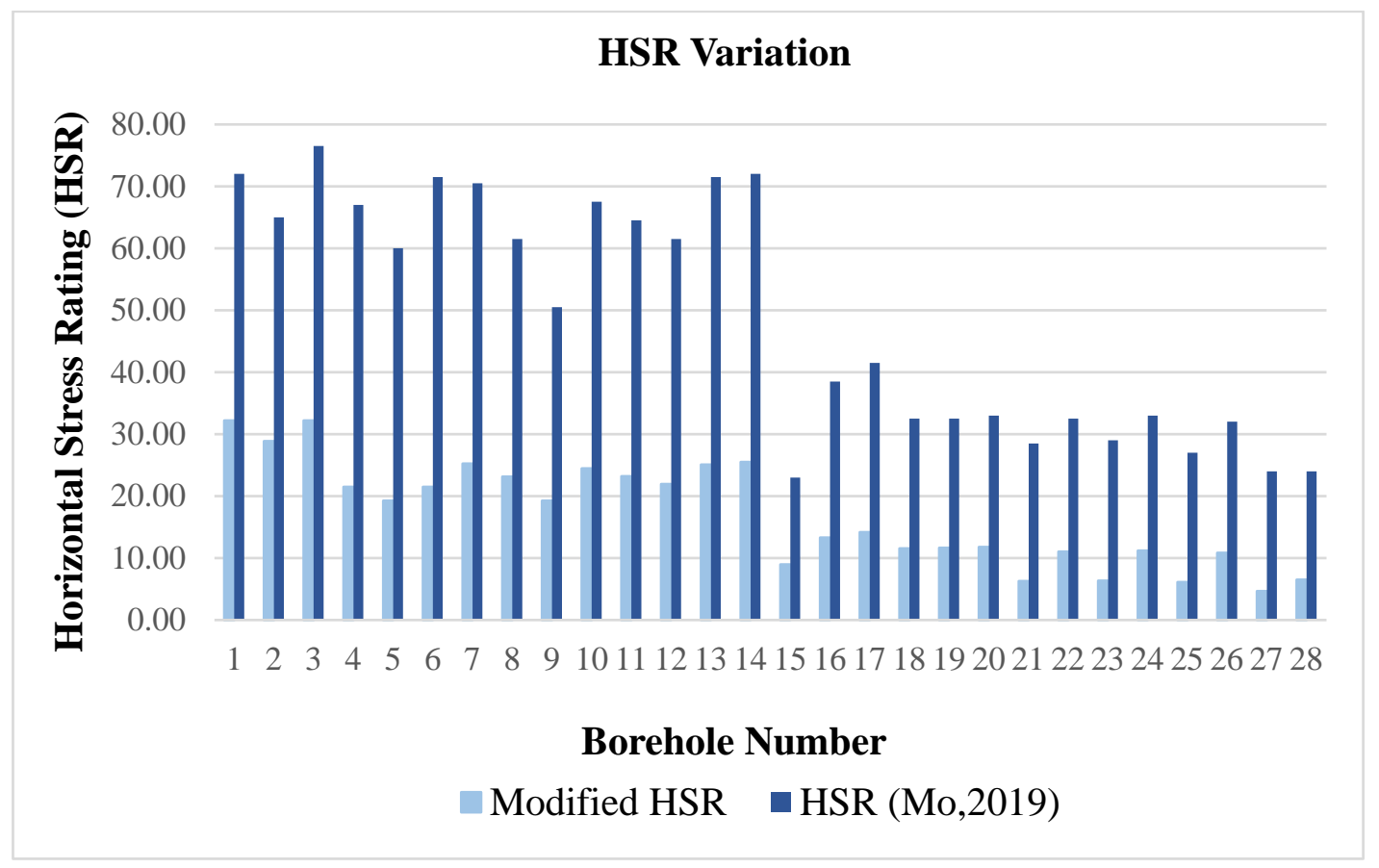

Figure 41. Variation in HSR.

\subsection{Re-analysis of cases based on Modified CMFR}

The modified CMFR and modified Horizontal Stress Rating proposed in the previous sections were then applied to the case study mines. Table 8 summarizes the modified CMFR along with orientation coefficients, and maximum horizontal stress and corresponding modified Horizontal Stress Rating (MHSR). Figure 42 shows the Floor Heave Index for the case study mines, plotted using the modified CMFR system. The dashed line is established to separate failure and nonfailure cases from each other. The proposed separation line provides $95.7 \%$ classification accuracy for the non-failure cases and 100\% classification accuracy for the failure cases. In contrast to the linear regression line in the FHI developed by Mo (2019), the dashed line is not 
plotted using linear regression. It is fitted into FHI in a way to obtain maximum classification accuracy. However, it should be also noted that the line is not established for design purposes and should be modified in the future if new case studies are included in the database.

Table 8. Modified CMFR and HSR.

\begin{tabular}{|c|c|c|c|c|c|c|}
\hline $\begin{array}{c}\text { Borehole } \\
\text { Name }\end{array}$ & $\begin{array}{c}\text { Failure or } \\
\text { Non- } \\
\text { failure }\end{array}$ & $\begin{array}{c}\text { Angle } \\
\left(^{\circ}\right) \\
\end{array}$ & $\begin{array}{l}\text { Orientation } \\
\text { Coefficient }\end{array}$ & $\begin{array}{c}\text { Maximum } \\
\text { Horizontal } \\
\text { Stress, MPa (psi) }\end{array}$ & $\begin{array}{c}\text { Modified } \\
\text { HSR }\end{array}$ & $\begin{array}{c}\text { Modified } \\
\text { CMFR }\end{array}$ \\
\hline BH 1 & Failure & 90 & 1.00 & 24.4 (3539) & 24.4 & 68 \\
\hline BH 2 & Failure & 90 & 1.00 & $21.1(3060)$ & 21.1 & 67 \\
\hline BH 3 & Failure & 90 & 1.00 & 24.4 (3539) & 24.4 & 75 \\
\hline BH 4 & Non-failure & 0 & 0.67 & 24.4 (3539) & 16.3 & 68 \\
\hline BH 5 & Non-failure & 0 & 0.67 & $21.1(3060)$ & 14.1 & 67 \\
\hline BH 6 & Non-failure & 0 & 0.67 & 24.4 (3539) & 16.3 & 75 \\
\hline BH 7 & Non-failure & 45 & 0.83 & $22.5(3263)$ & 18.8 & 70 \\
\hline BH 8 & Non-failure & 45 & 0.83 & 20.0 (2901) & 16.7 & 74 \\
\hline BH 9 & Non-failure & 45 & 0.83 & 15.3 (2219) & 12.8 & 85 \\
\hline BH 10 & Non-failure & 45 & 0.83 & $21.6(3133)$ & 18.0 & 70 \\
\hline BH 11 & Non-failure & 45 & 0.83 & 20.1 (2915) & 16.7 & 68 \\
\hline BH 12 & Non-failure & 45 & 0.83 & $18.6(2698)$ & 15.5 & 72 \\
\hline BH 13 & Non-failure & 45 & 0.83 & $22.3(3234)$ & 18.6 & 71 \\
\hline BH 14 & Non-failure & 45 & 0.83 & 22.8 (3307) & 19.0 & 63 \\
\hline BH 15 & Non-failure & 45 & 0.77 & 4.7 (682) & 3.6 & 63 \\
\hline BH 16 & Non-failure & 45 & 0.77 & $10.3(1494)$ & 7.9 & 71 \\
\hline BH 17 & Non-failure & 45 & 0.77 & $11.4(1653)$ & 8.8 & 67 \\
\hline BH 18 & Non-failure & 45 & 0.77 & $8.0(1160)$ & 6.2 & 70 \\
\hline BH 19 & Non-failure & 45 & 0.77 & 8.2 (1189) & 6.3 & 60 \\
\hline BH 20 & Non-failure & 45 & 0.77 & 8.3 (1204) & 6.4 & 68 \\
\hline BH 21 & Failure & 11 & 0.56 & $13.1(1900)$ & 7.3 & 52 \\
\hline BH 22 & Failure & 79 & 0.98 & $13.1(1900)$ & 12.9 & 52 \\
\hline BH 23 & Non-failure & 11 & 0.56 & $13.2(1914)$ & 7.4 & 63 \\
\hline
\end{tabular}




\begin{tabular}{llllccc} 
BH 24 & Non-failure & 79 & 0.98 & $13.2(1914)$ & 13.0 & 63 \\
BH 25 & Non-failure & 10 & 0.55 & $12.8(1856)$ & 7.1 & 62 \\
BH 26 & Non-failure & 80 & 0.99 & $12.8(1856)$ & 12.7 & 62 \\
BH 27 & Non-failure & 30 & 0.63 & $7.4(1073)$ & 4.7 & 59 \\
BH 28 & Non-failure & 60 & 0.88 & $7.4(1073)$ & 6.5 & 59 \\
\hline
\end{tabular}

\section{Floor Heave Index (FHI)}

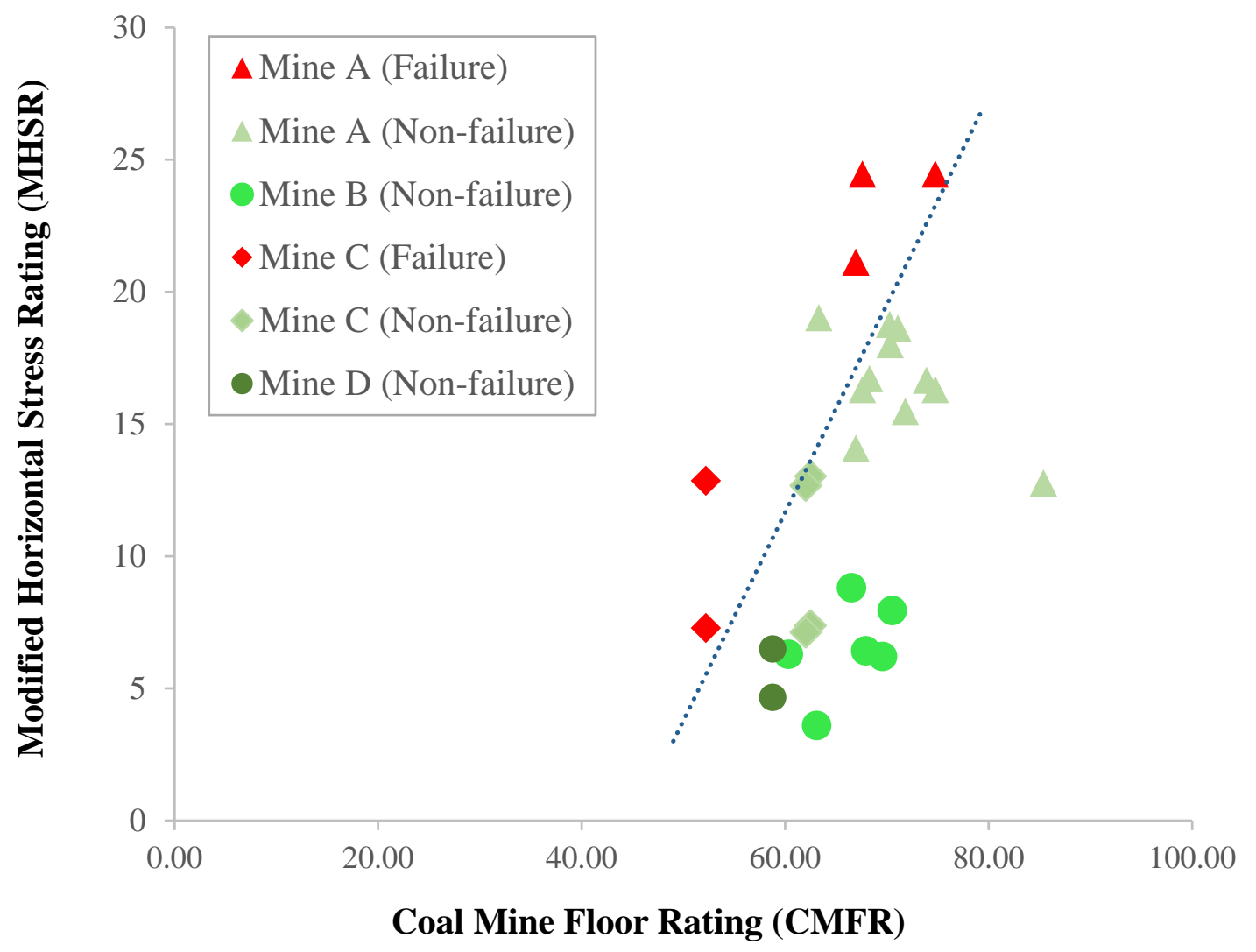

Figure 42. Floor Heave Index applying modified CMFR system. 


\section{Chapter 5 Summary and Conclusions}

\subsection{Summary}

Floor heave - the excessive deformation and failure of floor strata-is a serious problem for many underground coal mining operations in the U.S. Despite the major progress in reducing floor heave incidents in the Illinois coal basin of the U.S. underground mining sector, Sears et al. (2018) stated that floor heave is an increasing problem in the deep underground coal mines of other U.S. coal mining regions. In order to prevent stability problems associated with floor failure in this region, a systematic and proactive method to assess the potential of floor stability that also takes the floor failure mechanisms into consideration is a requirement.

Considering the lack of attention paid to the buckling floor failure mechanism in Eastern U.S. and the absence of a coal mine ground control design tool with a focus of floor stability analysis, this study utilized the Coal Mine Floor Rating (CMFR) system, a rock mass classification system recently developed by Mo (2019) for Australian coal mines derived from Coal Mine Roof Rating (CMRR) in the U.S. This system, which provides an indicator for the competence of floor strata, was applied to Eastern U.S. coal mines that intermittently experienced floor heave. This was done in order to propose a rock mass classification system as a regular floor stability analysis technique for the Eastern U.S. coal mines which experience buckling floor failure.

As an initial step to implement a floor stability methodology into floor design, a database was built from actual cases of stable and unstable floors across four currently active Eastern U.S. coal mines. Exploratory geologic drill log data, overburden maps, and mine plans were gathered in a broad database for this study. Additionally, qualitative data (failure/non-failure) on floor conditions of the mine entries near the core holes was collected and analyzed so that the floor quality and its relation to entry stability could be estimated by statistical methods. Then, the CMFR methodology was applied to floor stability at Eastern U.S. coal mines. This study examined the applicability of the CMFR outside of its domain, i.e. other than Australian coal mines, and investigated the potential factors for why it may not be applicable to Eastern U.S. coal mines.

The initial adaptation attempts indicated that the current CMFR classification system is not directly applicable in assessing the floor stability of Eastern U.S. coal mines. In order to incorporate the 
CMFR system into floor stability practices as a practical method, CMFR and HSR components of the CMFR system were modified, and new calculation procedures and factors were introduced.

\subsection{Conclusions}

This study found that the logistic regression line in FHI of the CMFR classification system proposed by Mo (2019) is not directly applicable in separating failure and non-failure cases from each other in Eastern U.S. coal mines. Through modifications on Coal Mine Floor Rating (CMFR) and Horizontal Stress Rating (HSR), as well as the addition of new parameters, the applicability of the CMFR system extended outside of its database which consisted of Australian case histories; as such, a successful adaption of the CMFR system enabled to the floor stability analysis of Eastern U.S. coal mines.

First, it was hypothesized that assigning a Unit Rating of 40 for a floor unit with UCS less than 10 MPa (1,450 psi) overestimates the competency of the floor unit; this hypothesis was supported by examples of weak floor units in the database. Consequently, the assumption of Unit Ratings for the floor units with UCS less than $10 \mathrm{MPa}(1,450 \mathrm{psi})$ decreased from 40 to 25 . Second, it was hypothesized that one of the major reasons for why failure and non-failure cases did not separate from each other using the original CMFR system's component in FHI (Figure 38) might be due to HSR. Therefore, HSR was revised and replaced with an elaborative but still practically applicable HSR. The depth rating of HSR, which calculates the effect of horizontal stress magnitude based on depth of cover was replaced with Equation 4.1 (Mark and Gadde, 2008) which evaluates the maximum horizontal stress based on stress field location and elastic modulus of rock in addition

to depth of cover. Moreover, the angle rating of HSR, which assigns the rating to unsystematically divided angle intervals, was substituted by a continuous angle rating scale by introducing an orientation coefficient.

By applying the modified CMFR, FHI was plotted and the separation line for failure and nonfailure cases was proposed (Figure 42). The proposed separation line had 95.7\% classification accuracy for the non-failure cases and 100\% classification accuracy for the failure cases. Detailed information including exploratory geologic drill log data, overburden maps, mine plans, and discussions with the mine engineers and geologists provided valuable insights to observed floor heaves in the Eastern U.S. and led to the achievement of high classification accuracy for the 
modified CMFR. Therefore, it was verified that the modified CMFR can be implemented as a practical and proactive floor design procedure for the Eastern U.S. coal mining industry.

This research study demonstrated the effectiveness of a rock mass classification system in preliminary floor stability analysis within the extent of the database. This study also shown that potential floor failures can be estimated through implementation of proper floor stability estimation techniques into regular ground control analysis in the Eastern U.S. which enables ensuring health and safety of miners. It also established a foundation for future adaptation studies of the CMFR system in regions other than the Eastern U.S. In order to apply the CMFR system for cases which do not share similar geologic settings and operational features, further modifications in the methodology would be required.

\subsection{Suggestions for Future Research}

Future research studies are recommended to focus on enlarging the database, primarily with buckling type floor heave and non-floor heave cases from active underground coal mines. The current database includes case histories of mines which experienced floor heave during the development stage of mining. The database can be also extended by adding case histories for the buckling mechanism during longwall retreat or pillar retreat. Further, a comprehensive empirical method can be proposed based on a database including case histories for the buckling mechanism during retreat mining.

None of case histories of mines in the database of this study have experienced floor heave due to exposure to moisture or water. Since it was not possible to understand the effect of moisture on floor stability, it is desirable to research the effect of moisture sensitivity and groundwater conditions in further studies by applying the CMFR system to case histories that experienced floor failure as a result of exposure to moisture or water. Accordingly, adding moisture sensitivity adjustments to the CMFR calculation procedure should be considered.

Strong unit adjustment (SUA) to the CMFR suggested by Mo (2019) was intended to apply to Eastern U.S. case histories. However, none of drill log samples and associated floor strata in the current database met the requirements to apply SUA during calculation of final CMFRs. Therefore, the applicability of SUA for Eastern U.S. mines and its functionality in the CMFR system were 
not thoroughly investigated. Upon addition of new cases histories, an attempt to verify SUA would be worthwhile. Particularly, the thickness limitation on the minimum strong layer thickness of 0.7 $\mathrm{m}(2.3 \mathrm{ft})$ should be further investigated by conducting sensitivity analysis with greater and lesser thickness limitations.

The discontinuity spacing rating of CMFR manually counts discontinuities and depends on the judgement of the practitioner. Although the potential for human errors remains, it is not a large concern as long as the average discontinuity spacing is evaluated by the same practitioner following a consistent method of discontinuity counting. In the case of extending the database to include case histories which are not close to each other, the evaluation of discontinuity spacing rating by the same practitioner would be difficult. For this reason, the discontinuity spacing calculation may be improved automation through the application of photogrammetry techniques.

\section{REFERENCES}

Afrouz, A. (1975a). Yield and bearing capacity of coal mine floor. International Journal of Rock Mechanics and Mining Sciences, 12(8):241-253.

Afrouz, A. (1975b). Floor behaviour along longwall roadways. International Journal of Rock Mechanics and Mining Sciences, 12(8):229-240.

Aggson, J. R. (1978). Coal mine floor heave in Beckley coalbed, an analysis. U.S. Department of the Interior, Bureau of Mines, Report of Investigations 8274.

Aggson, J. R., \& Curran, J. (1978). Coal mine ground control problems associated with a high horizontal stress field. Preprint Number 78-AM-14 (Society of Mining Engineers of AIME).

Aksoy, C. O. (2008). Review of rock mass rating classification: historical development, applications, and restrictions. Journal of Mining Science, 44(1):51-63.

Bamford, W. F. (1984). Rock test indices are being successfully correlated with tunnel boring machine performance. Proceedings of the 5th Australian Tunneling Conference, pp 9-22, Melbourne. 
Barefield, E., \& Shakoor, A. (2006). The effect of degree of saturation on the unconfined compressive strength of selected sandstones. Proceedings of the 10th IAEG International Congress - Engineering geology for tomorrow's cities, Nottingham, United Kingdom. (The Geological Society of London).

Barton, N. (1988). Rock mass classification and tunnel reinforcement selection using the Qsystem. ASTM STP 984, pp 59-88 West Conshohocken, Pennsylvania. (eds: L. Kirkaldie).

Barton, N. (2002). Some new Q-value correlations to assist in site characterization and tunnel design. International Journal of Rock Mechanics and Mining Science, 39(2):185-216.

Barton, N. R. (1999). TBM performance estimation in rock using Q (TBM). Tunnels and Tunneling International, 31(9):30-34.

Barton, N., \& Grimstad, E. (1994). The Q-system following twenty years of application in NMT support. Geomechanics Colloquy, 6(94):428-436.

Barton, N., Lien, R., \& Lunde, J. (1974). Engineering classification of rock masses for the design of tunnel support. Rock Mechanics, 6(4):189-236.

Beerkircher, M. D. (1994). Monterey Coal Company’s longwall project. Proceedings of the Illinois Mining Institute, pp 85-93, Collinsville, Illinois.

Bérest, P., Brouard, B., Feuga, B., \& Karimi-Jafari, M. (2008). The 1873 collapse of the SaintMaximilien panel at the Varangeville salt mine. International Journal of Rock Mechanics and Mining Sciences, 45(7):1025-1043.

Bieniawski, Z. T. (1973). Engineering classification of jointed rock masses. Transactions of the South African Institution of Civil Engineers, 15(12):335-344.

Bieniawski, Z. T. (1979). The geomechanics classification in rock engineering applications. Proceedings of the 4th International Congress on Rock Mechanics, pp 41-48, Montreux, Switzerland.

Bieniawski, Z. T. (1987). Strata Control in Mineral Engineering (J. Wiley \& Sons). 
Bieniawski, Z. T. (1989). Engineering Rock Mass Classifications: A Complete Manual for Engineers and Geologists in Mining, Civil and Petroleum Engineering (Wiley Interscience Publication).

Blindheim, O. T. (1979). Boreability predictions for tunneling. PhD thesis, Norwegian Institute of Technology, Trondheim, Norway.

Brady, B., \& Brown, E. (2004). Rock Mechanics for Underground Mining (Springer's).

Brown, J. D., \& Meyerhof, G. G. (1969). Experimental study on the bearing capacity in layered clays. Proceedings of the 7th International Conference on Soil Mechanics and Foundation Engineering, pp 45-51, Mexico City.

Bruland, A. (1998). Hard rock tunnel boring. PhD thesis, Norwegian University of Science and Technology (NTNU), Trondheim, Norway.

Buddery, P. S., Oldroyd, D., \& Hudson, J. A. (1992). Development of a roof and floor classification applicable to collieries. Proceedings of the Eurock '92, pp 197-202, Chester. (Thomas Telford Publishing).

Cai, M., \& Champaigne, D. (2012). Influence of bolt-grout bonding on MCB conebolt performance. International Journal of Rock Mechanics and Mining Sciences, 49:165-175.

Cartwright, P. B. (1997). A review of recent in-situ stress measurements in United Kingdom coal measure strata. Proceedings of the International Syposium on Rock Stress, pp 469-474, Kumamoto, Japan.

Cassie, J. W., Altounyan, P. F., \& Cartwright, P. B. (1999). Coal pillar design for longwall gate entries. Proceedings of the 2nd International Workshop on Coal Pillar Mechanics and Design, pp 23-32, Pittsburgh, Pennsylvania. U.S. Department of the Interior, Bureau of Mines, IC 9448.

Cassinelli, F., Cina, S., Unnaurato, N., Mancini, R., \& Sampaolo, A. (1982). Power consumption and metal wear in tunnel-boring machines: analysis of tunnel boring machine operation in hard rock. Tunneling 82, Proceedings of the 3rd International Symposium, pp 73-81, London. 
Cecil, O. S. (1970). Correlations of rock bolt shotcrete support and rock quality parameters in Scandinavian tunnels. PhD thesis, University of Illinois, Illinois.

Chandrashekhar, K. (1990). Effects of weak floor interaction on underground room-and-pillar coal mining. PhD thesis, Southern Illinois University, Carbondale, Illinois.

Chandrashekhar, K., Nath, R., \& Tandon, S. (1987). Design of coal pillars under weak floor conditions. Proceedings of the 28th U.S. Symposium on Rock Mechanics, pp 1073-1081.

Chase, F. E., Zipf, R. K., \& Mark, C. (1994). The massive collapse of coal pillars - case histories from the United States. Proceedings of the 13th International Conference on Ground Control in Mining, pp 69-80, Morgantown, West Virginia.

Cheema, S. (1999). Development of a rock mass boreability index for the performance of tunnel boring machines. PhD thesis, Colorado School of Mines, Colorado.

Chugh, Y. P. (1986a). Laboratory characteristics of immediate floor strata associated with coal seams in Illinois. Illinois State Geological Survey, Champaign, Illinois.

Chugh, Y. P. (1986b). In situ strength characteristics of coal mine floor strata in Illinois. Southern Illinois University, Carbondale, Illinois.

Chugh, Y. P., \& Missavage, R. A. (1981). Effects of moisture on strata control in coal mines. Engineering Geology, 17(4):241-255.

Chugh, Y. P., Nath, R., \& Shankar, S. (1987). Time-dependent behavior of immediate weak floor strata from an Illinois coal mine. Proceedings of the 6th International Conference on Ground Control in Mining, pp 204-218, Morgantown, West Virginia. (eds: S S Peng).

Cicek, S., Tulu, I. B., Van Dyke, M., Klemetti, T., \& Wickline, J. (2020). Application of the coal mine floor rating (CMFR) to assess the floor stability in a Central Appalachian coal mine. Proceedings of the 39th International Conference on Ground Control in Mining.

Coates, D. F. (1964). Classification of rocks for rock mechanics. International Journal of Rock Mechanics and Mining Sciences, 1(3):421-429.

Coates, D. F., \& Parsons, R. C. (1966). Experimental criteria for classification of rock substances. International Journal of Rock Mechanics and Mining Sciences, 3(3):181-189. 
Coduto, P. D., Yeung, M. C., \& Kitch, W. A. (2010). Geotechnical, Engineering, Principles and Practices (PHI Learning Private Ltd.).

Colwell, M., Frith, R., \& Hill, D. (2003). ALTS II-A longwall gateroad design methodology for Australian collieries. Proceedings of the 1st Australasian Ground Control in Mining Conference, pp 123-135, Sydney, Australia.

Colwell, M., Frith, R., \& Mark, C. (1999). Analysis of Longwall Tailgate Serviceability (ALTS) A chain pillar design methodology for Australian Conditions. Proceedings of the 2nd Workshop on Coal Pillar Mechanics and Design, pp 33-48, Pittsburgh, Pennsylvania. U.S. Department of the Interior, Bureau of Mines, IC 9448.

Cording, E. J., \& Deere, D. U. (1972). Rock tunnel supports and field measurements. Proceedings of the North American Rapid Excavation and Tunneling Conference, pp 601-622, Chicago, Illinois. (Society of Mining Engineers of AIME).

De Marco, M. J. (1994). Yielding pillar gate road design considerations for longwall mining. In New technology for longwall ground control, Pittsburgh, Pennsylvania. (eds: C Mark, RJ Tuchman, RC Repsher, CL Simon) pp 19-36.

Deere, D. U. (1963). Technical description of rock cores for engineering purposes. Rock Mechanics and Engineering Geology, 1(1):16-22.

Deere, D. U., \& Deere, D. W. (1988). The Rock Quality Designation (RQD) Index in practice. In Rock Classification Systems for Engineering Purposes. (eds: L Kirkaldie) ASTM STP 984, pp 91-101 (American Society for Testing and Materials).

Deere, D. U., \& Miller, R. P. (1966). Engineering classification and index properties for intact rock, Air Force Weapons Laboratory, Technical Report No. AFWL-TR-65-116.

Deere, D. U., Hendron, A. J., Patton, F. D., \& Cording, E. J. (1967). Design of surface and near surface construction in rock. Proceedings of the 8th U.S. Symposium on Rock Mechanics: Failure and breakage of rock, New York. (American Rock Mechanics Association).

Deere, D. U., Merritt, A. H., \& Coon, R. F. (1969a). Engineering classification of in-situ rock, U.S. Department of Commerce, Technical Report No. AFWL-TR-67-144. 
Deere, D. U., Peck, R. B., \& Parker, H. W. (1970). Design of tunnel support systems. Highway Research Record.

Deere, D. U., Peck, R. B., Monsees, J. E., \& Schmidt, B. (1969b). Design of tunnel liners and support systems, UIUC final report for U.S. Department of Transportation, Contract 30152 (U.S. Department of Commerce).

Dolinar, D. (2003). Variation of horizontal stresses and strains in mines in bedded deposits in the Eastern and Midwestern United States. Proceedings of the 22nd International Conference on Ground Control in Mining, pp 178-185, Morgantown, West Virginia.

Dou, L. M., \& He, X. Q. (2011). Bumping prevention and control theory and technology, Mining University Press, pp 5-10.

Einstein, H. H. (1989). Design and analysis of underground structures in swelling and squeezing rocks. In R. S. Sinha, Underground Structures: Design and Instrumentation. pp 203-262 (Elseiver).

Englund, K. J. (1979). The Mississippian and Pennsylvanian (Carboniferous) Systems in the United States: U.S. Geological Survey Professional Paper 1110-C, pp 1-21.

Esterhuizen, E., Mark, C., \& Murphy, M. (2010). Numerical model calibration for simulating coal pillars, gob and overburden response. Proceedings of the 29th International Conference on Ground Control in Mining, pp 46-57.

Esterhuizen, G., Ellenberger, J. L., \& Klemetti, T. (2015). A procedure for the rapid assessment of coal mine roof stability against large roof falls. Proceedings of the 34th International Conference on Ground Control in Mining, pp 217-224.

Faria Santos, C. (1988). Analysis of floor stability in underground coal mines. PhD thesis, Pennsylvania State University, Pennsylvania.

Faria Santos, C., \& Bieniawski, Z. T. (1989). Floor design in underground coal mines. Rock Mechanics and Rock Engineering, 22(4):249-271.

Farmer, I. W., \& Glossop, N. H. (1980). Mechanics of disc cutter penetration. Tunnels and Tunnelling International, 12(6):22-25. 
Feng, X. T., \& Hudson, J. A. (2011). Rock Engineering Design (CRC Press).

Franklin, J. A. (1970a). Classification of rock according to its mechanical properties. PhD thesis, University of London, London, United Kingdom.

Franklin, J. A. (1970b). Observations and tests for engineering description and mapping of rocks. Proceedings of the International Society of Rock Mechanics, pp 1-19. (International Society of Rock Mechanics).

Franklin, J. A. (1975). Safety and economy in tunneling. Proceedings of the 10th Canadian Rock Mechanics Symposium, pp 27-53.

Franklin, J. A., Broch, E., \& Walton, G. (1971). Logging the mechanical character of rock. Transactions of the Institution of Mining and Metallurgy, Section A: Mining Technology, 80(770):1-9.

Fredlund, D. G. (1996). Geotechnical problems associated with swelling clays. Developments in Soil Science, 24:499-524.

Freer, J. (1892). Mine creeps. Illinois Mining Journal, 1(3):238-243.

Fujii, Y., Ishijima, Y., Ichihara, Y., Kiyama, T., Kumakura, S., Takada, M., . . Nakata, E. (2011). Mechanical properties of abandoned and closed roadways in the Kushiro coal mine, Japan. International Journal of Rock Mechanics and Mining Sciences, 48(4):585596.

Gadde, M. M. (2009). Weak floor stability in the Illinois Basin underground coal mines. PhD thesis, West Virginia University.

Galvin, J. M. (2016). Ground Engineering-Principles and Practices for Underground (Springer International Publishing).

Galvin, J. M., Hebblewhite, B. K., \& Vasundhara. (1999). Geomechanics developments in mining coal under strong roof and weak floor conditions. Proceedings of the 9th International Society for Rock Mechanics Congress, Paris. 
Gong, Q. M., \& Zhao, J. (2009). Development of a rock mass characteristics model for TBM penetration rate prediction. International Journal of Rock Mechanics and Mining Sciences, 46(1):8-18.

Gonzalez de Vallejo, L. I. (1983). A new classification system for underground assessment using surface data. Proceedings of the International Symposium on Engineering Geology and Underground Construction, Lisbon, Portugal. (Laboratório Nacional de Engenharia Civil).

Graham, P. C. (1976). Rock exploration for machine manufacturers. In Z. T. Bieniawski, Exploration for rock engineering, pp 173-180.

Grim, R. E. (1968). Clay Mineralogy (McGraw-Hill Book Company).

Grima, M. A., Bruines, P. A., \& Verhoef, P. N. (2000). Modeling tunnel boring machine performance by neuro-fuzzy methods. Tunnelling and Underground Space Technology, 15(3):259-269.

Grimstad, E., \& Barton, N. (1993). Updating the Q-system for NMT. Proceedings of the International Symposium on Sprayed Concrete-Modern use of wet mix sprayed concrete for underground support, Fagernes, Oslo. (Norwegian Concrete Association).

Guangyu, L., Shiwei, B., \& Jiguang, L. (1986). Twenty years of experience on in-situ stress measurements in China. Proceedings of the International Syposium on Rock Stress an Rock Stress Measurements, pp 79-88, Stockholm, Sweden.

Hall, R. D. (1909). Squeeze in mines and their causes. Mines and Miner, 30(5):286-287.

Hanna, A. M. (1982). Bearing capacity of foundations on a weak sand layer overlying a strong deposit. Canadian Geotechnical Journal, 19(3):392-396.

Hasenfus, G. J., \& Su, D. W. (1992). A comprehensive integrated approach for longwall development design. Proceedings of the Workshop on Coal Pillar Mechanics and Design, pp 225-237, Pittsburgh, Pennsylvania. U.S. Department of the Interior, Bureau of Mines, IC 9315. 
Hawkins, A., \& McConnell, B. (1992). Sensitivity of sandstone strength and deformability to changes in moisture content. Quarterly Journal of Engineering Geology and Hydrogeology, 25(2):115-130.

Heasley, K. (1998). Numerical modelling of coal mines with a laminated displacement continuity code. PhD thesis, Colorado School of Mines, Colorado.

Heasley, K. A. (2009). An overview of calibrating and using the LaModel program for coal mine design. Proceedings of the International Workshop on Numerical Modeling for Underground Mine Excavation Design, pp 63-74, Asheville, North Carolina. U.S. Department of Health and Human Services, NIOSH Information Circular 9512.

Heasley, K. A. (2012). Calibrating the Lamodel program for site specific conditions. Proceedings of the 31st International Conference on Ground Control in Mining, pp 1-8, Morgantown, West Virginia.

Heasley, K. A., Sears, M. M., Tulu, I. B., Calderon-Arteaga, C. H., \& Jimison, W. L. (2010). Calibrating the LaModel program for deep cover pillar retreat coal mining. Proceedings of the 3rd International Workshop on Coal Pillar Mechanics and Design, pp 47-57, Morgantown, West Virginia.

Hennen, R. V. (1915). Wyoming and McDowell Counties: West Virginia Geological Survey (County Report), p 783.

Hennen, R. V. (1919). Fayette County: West Virginia Geological Survey (County Report), p 1002.

Herdy, A. C., \& Townsend, F. C. (1982). Preliminary investigation of bearing capacity of layered soils by centrifugal modeling. Transportation Research Record 872, pp 20-24.

Hoek, E. (1994). Strength of rock and rock masses. ISRM News Journal, 2(2):4-16.

Hoek, E. (2000). Big tunnels in bad rock: 2000 Terzaghi lecture. ASCE Journal of Geotechnical and Geoenvironmental Engineering, 127(9):726-740.

Hoek, E. (2007). Practical Rock Engineering (RocScience). 
Hoek, E., \& Brown, E. T. (1997). Practical estimates of rock mass strength. International Journal of Rock Mechanics and Mining Sciences, 34(8):1165-1186.

Hoek, E., Marinos, P., \& Benissi, M. (1998). Applicability of the geological strength index (GSI) classification for very weak and sheared rock masses: the case of the Athens Schist Formation. Bulletin of Engineering Geology and the Environment, 57(2):151-160.

Hudson, J. A., \& Harrison, J. P. (2000). Engineering Rock Mechanics: Part 2: Illustrative Worked Examples (eds: ME Popescu) (Pergamon).

Iida, R., \& and others. (1970). Geological rock classification of dam foundations. Rock Mechanics, V1, p171.

Innaurato, N., Mancini, R., Rondena, E., \& Zaninetti, A. (1991). Forcasting and effective TBM performance in a rapid excavation of a tunnel in Italy. Proceedings of the 7th International Congress Rock Mechanics, pp 1009-1014, Aachen, Germany. (eds: W Wittke).

Jayanti, S. (1991). A finite element analysis of bearing capacity of coal pillars on weak floor strata. $\mathrm{PhD}$ thesis, Southern Illinois University, Carbondale, Illinois.

Jenkins, J. D. (1955). Mechanics of floor penetration in mines. Iron and Coal Trades Review, 171(4560):541-547.

Jenkins, J. D. (1958). Some Investigations into the bearing capacities of floors in the Northumberland and Durham coalfields. Transactions of the Institution of Mining and Metallurgy, 117(2):725-738.

Jenkins, J. D. (1960). A laboratory and underground study of the bearing capacity of mine floors. Proceedings of the 3rd International Conference of Strata Control, pp 227-240, Paris.

Jeremic, M. L. (1981). Coal mine roadway stability in relation to lateral tectonic stress in western Canada. Mining Engineering, 33(6):704-709.

John, K. W. (1962). An approach to rock mechanics. Journal of the Soil Mechanics and Foundations Division, 88(4):1-30.

Jones, E. (1897). The control of creeps. Colliery Eng. and Met. Monit., 18(3):111-113. 
Kaiser, P. K., Tannant, D. D., \& McCreath, D. R. (1996). Canadian rockburst support handbook. Geomechanics Research Centre, Laurentian University, Sudbury, Canada.

Kalamaras, E. S., \& Bieniawski, Z. T. (1995). A rock mass strength concept for coal seams incorporating the effect of time. Proceedings of the International Society of Rock Mechanics Congress, pp 295-302, Balgema, Japan.

Kalantari, B. (2012). Engineering significant of swelling soils. Research Journal of Applied Sciences, Engineering and Technology, 4(7):2874-2878.

Karabin, G. J., \& Evanto, M. A. (1994). Experience with boundary element method of numerical modelling as a tool to resolve complex ground control problems. Proceedings of the 13th International Conference on Ground Control Problems, pp 201-213, Morgantown, West Virginia .

Keatley, J. P. (1929). Report on the Glen Rogers Mine, Raleigh-Wyoming Company, Glen Rogers (West Virginia State Department of Mines).

Kendorski, F. S., Cummings, R. A., Bieniawski, Z. T., \& Skinner, E. H. (1983). Rock mass classification for block caving mine drift support. Proceedings of the 5th International Society of Rock Mechanics, Melbourne.

Klemetti, T., Van Dyke, M. E., Compton, C. C., \& Tulu, I. (2020). Insights into the relationships among the roof, rib, floor and pillars of underground coal mines. Mining, Metallurgy and Exploration, https://doi.org/10.1007/s42461-020-00313-7.

Krebs, C. E. (1916). Raleigh County and the western portions of Mercer and Summers Counties: West Virginia Geological Survey (County Report), p 778.

Krishna, R., \& Whittaker, B. N. (1973). Floor lift in mine roadways. Colliery Guardian, 221(11):396-402.

Kwasniewski, M. (1990). Effect of moisture on the mode of deformation and failure of coal measure mudstone under triaxial compression. Proceedings of the Strata Control in Deep Mines, pp 169-186, Balkema, Rotterdam. 
Lang, B. (1994). Span design for entry type excavations. MSc thesis, University of British Columbia, Vancouver, Canada.

Latilla, J. (2004). Weak floors and their influence on pillar stability on Southern African collieries. Proceedings of SANIRE-The Miner's Guide through the Earth Crust, pp 71-78. (South African Institue of Rock Engineering).

Laubscher, D. H. (1975). Class distinction in rock masses. Coal, Gold, Base ,Minerals S. Afr. 23.

Laubscher, D. H. (1990). A geomechanics classification system for the rating of rock mass in mine design. Journal of the South African Institute of Mining and Metallurgy, 90(10):257-273.

Laubscher, D. H., \& Taylor, H. W. (1976). The importance of geomechanics classification of jointed rock mass in mining operations. Proceedings of the Symposium Exploration for Rock Engineering, Johannesburg, South Africa.

Lauffer, H. (1958). Classification for tunnel construction. Geologie und Bauwesen, 24(1):46-51.

Lee, R. D. (1961). Testing mine floor. Colliery Engineering, 38(448):255-261.

Li, X., Wang, E., Li, Z., Liu, Z., Song, D., \& Qiu, L. (2016a). Rock burst monitoring by integrated microseismic and electromagnetic radiation methods. Rock Mechanics and Rock Engineering, 49(11):4393-4406.

Li, Z.-l., Dou, L.-m., Cai, W., Wang, G.-f., Ding, Y.-l., \& Kong, Y. (2016b). Roadway stagger layout for effective control of gob-side rock bursts in the longwall mining of a thick coal seam. Rock Mechanics and Rock Engineering, 49(2):621-629.

Lu, S., \& Jiang, Y. (1998). The control of support resistance over strata around roadway in soft rock. Rock and Soil Mechanics, 19(1):1-6.

Luo, J., Haycocks, C., \& Karmis, M. (1997). Design in overlying multiple seam mines. SME Preprint 97-107, pp 11.

Macias, F. J., Eide, L. N., Jakobsen, P. D., Jacobs, C., \& Bruland, A. (2015). Performance prediction assessments of a hard rock TBM used in mining development. Proceedings of the Rapid Excavation and Tunneling Conference, New Orleans, Louisiana. 
Mandel, J., \& Salencon, J. (1969). Force portante d'un sol sur une assise rigide. Proceedings of the 7th International Conference on Soil Mechanics and Foundation Engineering, pp 157-164, Mexico. (Sociedad Mexicana de Mecanica).

Marino, G. (1985). Subsidence damaged homes over room and pillar mines in Illinois. $\mathrm{PhD}$ thesis, University of Illinois, Urbana-Champaign, Illinois.

Mark, C. (1990). Pillar design methods for longwall mining. U.S. Bureau of Mines Information Circular 9247, pp 55.

Mark, C. (1992). Analysis of longwall pillar stability (ALPS): an update. Proceedings of the Workshop on Coal Pillar Mechanics and Design, pp 238-249, Washington DC. U.S. Department of Interior, Bureau of Mines, Information Circular 9315.

Mark, C. (2000). Design of roof bolt systems. Proceedings of the New Technology in Roof Support. U.S. Department of Health and Human Services, Public Health Service, Centers for Disease Control and Prevention, National Institute for Occupational Safety and Health, DHHS (NIOSH), Information Circular 9453.

Mark, C. (2009). Deep cover pillar recovery in the U.S. Proceedings of the 28th International Conference on Ground Control in Mining, pp 1-9, Morgantown, West Virginia.

Mark, C. (2010). ARMPS 2010: pillar design for deep cover retreat mining. Proceedings of the 2nd International Workshop on Coal Pillar Mechanics and Design, pp 106-122. U.S. NIOSH.

Mark, C., \& Agioutantis, Z. (2018). Analysis of Coal Pillar Stability (ACPS): A new generation of pillar design software. International Journal of Mining Science and Technology, 29(1):87-91.

Mark, C., \& Barczak, T. M. (2000). Fundamentals of coal mine roof support. In Proceedings of the New Technology for Coal Mine Roof Support. (eds: C Mark, DR Dolinar, RJ Tuchman, TM Barczak, SP Signer, PF Wopat) NIOSH Open Industry Briefing IC 9453, pp 23-42. 
Mark, C., \& Bieniawski, Z. T. (1986). An emprical method for the design of chain pillars in longwall mining. Proceedings of the 27th U.S. Symposium on Rock Mechanics, New York, NY, pp 415-422. American Institute of Mining, Metallurgical, and Petroleum Engineers.

Mark, C., \& Chase, F. E. (1997). Analysis of retreat mining pillar stability. Proceedings of the NIOSH Technology Transfer Seminar, pp 17-34. U.S. NIOSH IC 9446.

Mark, C., \& Gadde, M. M. (2008). Global trends in coal mine horizontal stress measurements. Proceedings of the 27th International Conference on Ground Control in Mining Conference, pp 319-331, Morgantown, West Virgina.

Mark, C., \& Molinda, G. (1994). Coal Mine Roof Rating (CMRR): A practical rock mass classification for coal mines, Bureau of Mines, Pittsburgh Research Center, Pittsburgh, Pennsylvania.

Mark, C., \& Molinda, G. M. (2005). The Coal Mine Roof Rating (CMRR)—a decade of experience. International Journal of Coal Geology, 64(1):85-103.

Mark, C., \& Molinda, G. M. (2007). Development and application of the Coal Mine Roof Rating (CMRR). Proceedings of the International Workshop on Rock Mass Classification in Underground Mining, pp 95-110.

Mark, C., Chase, F. E., \& Pappas, D. M. (2007). Analysis of multiple-seam stability. Proceedings of the 26th International Conference on Ground Control in Mining, pp 5-18, Morgantown, West Virginia.

Mark, C., Molinda, G., \& Dolinar, D. R. (2001). Analysis of roof bolt systems (ARBS). Proceedings of the 20th International Conference on Ground Control in Mining, pp 218225, Morgantown, West Virginia.

Matetic, R. J., Chekan, G. J., \& Galek, J. A. (1987). Pillar load transfer associated with multipleseam mining. U.S. Department of Interior, Bureau of Mines, Report of Investigations 9066. 
Mathis, J. I., \& Page, C. H. (1995). Drifting in very poor rock-experience and analysis. Proceedings of the 101st annual Northwest Mining Association Convention, Spokane, Washington.

McColloch, G. H. (1995). Keystone Coal Industry Manual, pp. 178-188 (Intertec Publishing Company).

McFeat-Smith, I. (1999). Mechanised tunnelling for Asia. Workshop Manual, IMS Tunnel Consultancy Ltd.

McGarr, A. (1988). On the state of lithospheric stress in the absence of applied tectonic forces. Journal of Geophysical Research, 93(11):13609-13617.

Merritt, A. H. (1972). Geologic predictions for underground excavations. Proceedings of the North American Rapid Excavation and Tunneling Conference, pp 115-132.

Meyerhof, G. G. (1974). Ultimate bearing capacity of footing on sand layer overlying clay. Canadian Geotechnical Journal, 11(2):223-229.

Mills, K. W., \& Edwards, J. L. (1997). Review of pillar stability in claystone floor. Proceedings of the Symposium on Safety in Mines: The Role of Geology, pp 161-168, Newcastle, New South Wales. (eds: R Doyle, J Moloney, J Rogis, M Sheldon) (Coalfield Geology Council of New South Wales).

Milne, D., Hadjigeorgiou, J., \& Pakalnis, R. (1998). Rock mass characterization for underground hard rock mines. Tunnelling and Underground Space Technology, 13(4):383-391.

Mo, S. (2019). Floor heave mechanics in underground coal mine roadways. PhD thesis, University of New South Wales, Sydney, Australia.

Mo, S., Tutuk, K., \& Saydam, S. (2018). Proceedings of the 37th International Conference of Ground Control in Mining, pp 122- 130, Morgantown, West Virginia. (eds: B Mishra, TM Klemetti, H Lawson, MM Murphy, KA Perry).

Mohamed, K. M., Zhao, C., \& Rashed, G. (2019). Coal rib stability based on the strength reduction of the coal mass model. Proceedings of the 53rd U.S. Rock Mechanics and 
Geomechanics Symposium, Seattle, Washington. (American Rock Mechanics Association).

Mohamed, K., Van Dyke, M., Rashed, G., Sears, M. M., \& Kimutis, R. (2020). Preliminary rib support requirements for solid coal ribs using a coal pillar rib rating. Proceedings of the 39th International Conference on Ground Control in Mining, pp 85-96.

Molinda, G. M., \& Mark, C. (1993). The Coal Mine Roof Rating (CMRR) - a practical rock mass classification for coal mines. Proceedings of the 12th Conference on Ground Control in Mining, pp 92-103, Morgantown, West Virginia. (ed: S S Peng).

Molinda, G. M., \& Mark, C. (1994). U.S. Department of Interior, Bureau of Mines, IC 9387: The Coal Mine Roof Rating (CMRR)-A practical rock mass classification for coal mines.

Molinda, G. M., \& Mark, C. (1996). Rating the strength of coal mine roof rocks. Proceedings of the 2nd North American Rock Mechanics Symposium, pp 413-422, Montréal, Québec, Canada . (NARMS'96, International Society for Rock Mechanics).

MSHA. (2019). Retrieved March, 2019, from https://arlweb.msha.gov/OpenGovernmentData/OGIMSHA.asp.

MSHA. (2020). Mine Data Retrieval System. Retrieved 09 23, 2020 from https://www.msha.gov/mine-data-retrieval-system.

MSHA. (2020). MSHA Data Retrieval Systsem. Retrieved 10 20, 2020 from https://www.msha.gov/mine-data-retrieval-system.

Murphy, M. M. (2020). Personal communication.

Murphy, M. M., Ellenberger, J. L., Esterhuizen, G. S., \& Miller, T. (2015a). Roof and pillar failure associated with weak floor at a limestone mine. Proceedings of the Annual Meeting, Denver, Colorado . (Society for Mining, Metallurgy \& Exploration).

Murphy, M. M., Esterhuizen, G. S., Ellenberger, J. L., \& Miller, T. (2015b). Analysis of roof and pillar failure associated with weak floor at a limestone mine. Proceedings of the 34th International Conference on Ground Control in Mining, pp 195-201. 
Nelson, A. (1947). Floor movements and their control. Iron and Coal Trades Review, vol 146, No 4136.

Nelson, P. P., Yousof, A. A.-J., \& Laughton, C. (1999). Improved strategies for TBM performance prediction and project management. Proceedings of the Rapid Excavation and Tunneling Conference, pp 963-979.

Nemcik, J. (2003). Floor failure mechanism at underground longwall face. $\mathrm{PhD}$ thesis, University of Wollongong, Australia.

Newman, D. A. (1985). The design of coal mine roof support and yielding pillars for longwall mining in the Appalachian coalfield. PhD thesis, Pennsylvania State University, Pennsylvania.

Newman, D. A., \& Bieniawski, Z. T. (1985). A modified version of the geomechanics classification: for entry design in underground coal mines (Society of Mining Engineers of AIME).

NGI. (2015). Handbook: Using the Q-System. Rock mass classification and support design. (Norwegian Geotehnical Institute).

Nolde, J. E. (1994a). Devonian to Pennsylvanian stratigraphy and coal beds of the Appalachian Plateaus Province. Geology and mineral resources of the southwest Virginia coalfield: Virginia Division of Mineral Resources Publication 131, pp 1-85.

Nolde, J. E. (1994b). Coal beds, coal zones, and key stratigraphic names in the Pennsylvanian units of southwestern Virginia: Virginia Division of Mineral Resources Publication 136.

O’Rourke, J. E., Spring, J. E., \& Coudray, S. V. (1994). Geotechnical parameters and tunnel boring machine performance at goodwill tunnel. Proceedings of the 1st North American Rock Mechanics Symposium, Austin, Texas. (eds: PP Nelson, SE Laubach).

Odom, I. E., \& Parham, W. E. (1968). Petrography of Pennsylvanian underclays in Illinois and their application to some mineral industries. Illinois State Geological Survey Circular 429. 
Onargan, T., Koca, M. Y., Kucuk, K., Deliormanli, A., \& Saydam, S. (2004). Impact of the mechanical characteristics of weak rocks and trona ore beds on the main drift deformation at the Beypazari mine, Turkey. International Journal of Rock Mechanics and Mining Sciences, 41(4):641-654.

Onargan, T., Kucuk, K., Deliormanli, A., Saydam, S., \& Koca, M. Y. (2012). Ground control for underground evaporite mine in Turkey . In Mining Methods (eds: T Onargan) pp 33-46.

Onodera, T. F. (1970). Activities in rock mechanics in the Japanese Society of Soil Mechanics and Foundation Eng. Rock Mechanics, V1.

Palmström, A. (1995). RMi-a rock mass characterization system for rock engineering purposes. PhD thesis, University of Oslo, Oslo, Norway.

Palmström, A. (2000). Recent developments in rock support estimates by RMi. Journal of Rock Mechanics and Tunneling Technology, 6(1):1-19.

Peck, R. B., Deere, D. U., Monsees, J. E., Parker, H. W., \& Schmidt, B. (1969). Some design considerations in the selection of underground support systems, UIUC final report for U.S. Department of Transportation (U.S. Department of Commerce).

Peng, S. S. (1994). Mechanism and Control of Floor Heaves. Unpublished Report (West Virginia University).

Peng, S. S. (2015). Topical areas of research needs in ground control-A state of the art review on coal mine ground control. International Journal of Mining Science and Technology, 25(1):1-6.

Peng, S. S., Wang, Y. J., \& Tsang, P. (1995). Analysis of Floor Heave Mechanism. Proceedings of the SME Annual Meeting, Denver, Colorado. (Society of Mining, Metallurgy \& Exploration).

Perry, K. A., Bradley, J., Unrug, K. F., \& Klimek, M. (2015). Floor heave control outby the seal line in No.11 West Kentucky seam. Proceedings of the 34th International Conference on Ground Control in Mining, pp 169-173, Morgantown, West Virginia. (eds: TM Barczak, SS Peng, D Schmidt, SC Tadolini, M Thompson). 
Plass, W. T., \& Vogel, W. G. (1973). Chemical properties and particle-size distribution of 39 surface mine spoils in Southern West Virginia, U.S. Department of Agriculture, Forest Service Research Paper NE-276.

Price, P. H. (1939). Greenbrier County: West Virginia Geological Survey (County Report), p 846.

Priest, S. D. (1993). Discontinuity Analysis for Rock Engineering (Springer).

Pytel, W. M. (1998). 3D roof-pillar-floor interaction analysis model, p 315 (CUPRUM).

Qi, Q. X., Zhao, S. K., \& Zhang, N. B. (2013). Prediction and prevention technology of rock burst based on stress control theory. In Rock Dynamics and Applications State of Art. (eds: J Zhao, J Li) pp 591-596.

Rabcewicz, L. V. (1964). The new Austrian tunneling method. Water Power, Part one, 453-457.

Rabcewicz, L. V. (1965). The New Austrian Tunneling Method. Water Power, Part two, 511515.

Rabcewicz, L. V. (1975). Tunnel under Alps uses new, cost-saving lining method. ASCE Civil Engineering, 45(10):66-68.

Rashed, G., Mohamed, K. M., \& Kimutis, R. (2020). A coal rib monitoring study in a room-andpillar retreat mine. Proceedings of the 39th International Conference on Ground Control in Mining, pp 237-246.

Reger, D. B. (1926). Mercer, Monroe, and Summers Counties: West Virginia Geological Survey (County Report), p 963.

Richardson, A., Agapito, J. F., \& Gilbride, L. (1999). Rock mechanics issues in the trona patch. Proceedings of the 18th Conference on Ground Control in Mining, pp 194-201, Morgantown, West Virginia. (eds: SS Peng, C Mark).

Riefenberg, J. (1995). Towards a method of determining floor quality in an underground coal mine. Proceedings of the 14th Conference on Ground Control in Mining, pp 200-208, Morgantown, West Virginia. 
Ritter, W. (1879). Die statik der tunnelgewölbe (Springer).

Rockaway, J. D., \& Stephenson, R. W. (1979). Investigation of the effects of weak floor conditions on the stability of coal pillars. Report No. BUMINES-ofr-12-81.

Romana, M. (1985). New adjustment ratings for application of Bieniawski classification to slopes. Proceedings of the International Symposium on Role of Rock Mechanics, pp 4953, Zacatecas, Mexico.

Romana, M., Seron, J. B., \& Montalar, E. (2003). SMR Geomechanics classification: application, experience and validation. Proceedings of the 10th Congress of the International Society for Rock Mechanics, pp 1-4, Sandton, South Africa.

Rostami, J. (1997). Development of a force estimation model for rock fragmentation with disc cutters through theoretical modeling and physical measurement of crushed zone pressure. $\mathrm{PhD}$ thesis, Colorado School of Mines, Colorado.

Rostami, J., \& Ozdemir, L. (1993). A new model for performance prediction of hard rock TBM. Proceedings of the Rapid Excavation and Tunneling Conference, pp 793-809, Boston, Massachusetts. (eds: LD Bowerman et al.).

Ruppert, L. F., Tewalt, S. J., Wallack, R. N., Bragg, L. J., Brezinski, D. K., Carlton, R. W., . . Calef, F. J. (2000). A digital resource model of the Middle Pennsylvanian Upper Freeport Coal Bed, Allegheny Group, Northern Appalachian Basin Coal Region. US Geological Survey Professional Paper 1625-C. Chapter D.

Sainsbury, B.-A. L. (2003). An investigation of the pillar system stability over softened claystone floors at the Cooranbong colliery. MSc thesis, University of New South Wales, Sydney, Australia.

Sapigni, M., Berti, M., Bethaz, E., Busillo, A., \& Cardone, G. (2002). TBM performance estimation using rock mass classifications. International Journal of Rock Mechanics and Mining Sciences, 39(6):771-788. 
Saydam, S., Onargan, T., \& Deliormanli, A. (2003). The relationship between slake durability and geomechanical properties for upper rocks of Beypazari trona bed in Ankara, Turkey. Journal of the South African Institute of Mining and Metallurgy, 103(4):241-250.

Sears, M. M. (2020). Personal communication.

Sears, M. M., \& Heasley, K. A. (2013). Calibrating the LaModel program for shallow cover multiple-seam mine. Proceedings of the 32nd International Conference on Ground Control in Mining, pp 99-106.

Sears, M., Van Dyke, M., Klemetti, T., Su, W. H., \& Tulu, I. (2018). The effect of floor strength and horizontal stress orientation on floor heave in a deep U.S. longwall mine. Proceedings of the 52nd U.S. Rock Mechanics and Geomechanics Symposium, Seattle, Washington. (American Rock Mechanics Association).

Seedsman, R. (2012). The strength of the pillar-floor system. Proceedings of the 12th Coal Operator's Conference, pp 23-30, Wollongong, New South Wales.

Seneviratne, S. P. (1986). Design of partial extraction systems for mining in New South Wales. $\mathrm{PhD}$ thesis, University of New South Wales, Sydney, Australia.

Serata, S., Carr, F., \& Martin, E. (1984). Stress control method applied to stabilization of underground coal mine openings. Proceedings of the 25th US Symposium on Rock Mechanics, pp 583-590, Evanston, Illinois. (American Rock Mechanics Association).

Shakoor, A., \& Barefield, E. (2009). Relationship between unconfined compressive strength and degree of saturation for selected sandstones. Environmental and Engineering Geoscience, 15(1):29-40.

Shankar, S. (1987). Geotechnical properties of immediate floor strata from an Illinois coal mine. $\mathrm{PhD}$ thesis, Southern University, Carbondale, Illinois.

Sheffield, P., \& Corbett, P. (2018). Managing floor heave in an underground longwall coal mine. Proceedings AusRock 2018: The 4th Australasian Ground Control in Mining Conference, pp 78-94, Sydney, Australia. 
Sheorey, P. R. (1991). Application of modern rock mass classifications in coal mines. Proceedings of the Workshop on Tunnels, Mine Roadways and Caverns, Ooty, India.

Signer, S. P. (1994). Field evaluations of grouted roof bolts. Proceeding of the U.S. Bureau of Mines Technology Transfer Seminar, pp 91-101. U.S. Department of the Interior, Bureau of Mines, New Technology For Longwall Ground Control, Special Publication 01-94.

Singh, B., \& Goel, R. K. (1999). Rock Mass Classification-A Practical Approach in Civil Engineering (Elsevier).

Singh, M. M., \& Cummings, R. A. (1983). Predicting moisture-induced deterioration of shales. Proceedings of the 5th ISRM Congress, pp 87-95, Melbourne, Australia. (International Society for Rock Mechanics).

Sizer, K., \& Gill, M. (2000). Pillar failure in shallow coal mines-a recent case history. Mining Technology , 109(3):146-152.

Slaker, B. A., \& Murphy, M. M. (2018). Analysis of extensometer, photogrammetry and laser scanning monitoring techniques for measuring floor heave in an underground limestone mine. Transactions of Society for Mining, Metallurgy, and Exploration. 344(1):31-37.

Slaker, B. A., Murphy, M. M., \& Miller, T. (2017). Analysis of monitoring techniques to measure floor heave in an underground limestone mine. Proceedings of the SME Annual Meeting, pp 54-58. (Society for Mining, Metallurgy \& Exploration).

Slaker, B. A., Westman, E., Ellenberger, J., \& Murphy, M. M. (2015). Time-lapse photogrammetric monitoring of an underground stone mine. Proceedings of the 34th International Conference on Ground Control in Mining, pp 274-278.

Sliwa, R., Hatherly, T., Medhurst, T., \& Turner, R. (2006). Quantitative geophysical log interpretation for geotechnical and geological assessment of coal measure rocks. Proceedings of the 6th International Mining Geology Conference, pp 117-125, Darwin, NT, Australia. 
Spears, D., \& Taylor, R. (1972). The influence of weathering on the composition and engineering properties of in-situ coal measures rocks. International Journal of Rock Mechanics and Mining Sciences and Geomechanics, 9(6):729-730.

Speck, C. R. (1979). A comparative evaluation of geologic factors Influencing floor stability in two Illinois coal mines. PhD Thesis, University of Missouri, Missouri.

Speck, C. R. (1981). The influence of certain geologic and geotechnical factors on coal mine floor stability - A case study. Proceedings of the 1st Conference on Ground Control in Mining, pp 44-49, Morgantown, West Virginia.

Sundaram, N. M., Rafek, A. G., \& Komoo, I. (1998). The influence of rock mass properties in the assessment of TBM performance. Proceedings of the 8th International IAEG Congress, pp 3353-3359, Balkema, Rotterdam.

Tandon, S. (1987). Field strength-deformation characteristics of immediate floor strata in Illinois coal mines. PhD thesis, Southern Illinois University, Carbondale.

Taylor, R. (1988). Coal measures mudrocks: composition, classification and weathering processes. Quarterly Journal of Engineering Geology and Hydrogeology, 21(1):5-99.

Taylor, R. K., \& Spears, D. A. (1970). The breakdown of British coal measure rocks. International Journal of Rock Mechanics and Mining Sciences and Geomechanics, 7(5):481-501.

Terzaghi, K. (1946). Rock defects and loads in tunnel supports (Commercial Shearing and Stamping Company).

Tulu, I. B., Esterhuizen, G. S., Gearhart, D. F., Klemetti, T. M., Mohamed, K. M., \& Su, D. W. (2017). Analysis of global and local stress changes in a longwall gateroad. Proceedings of the 36th International Conference on Ground Control in Mining, pp 100-110.

Unal, E. (1983). Development of design guidelines and roof-control standards for coal-mine roofs. PhD thesis, Pennsylvania State University, Pennsylvania.

Underwood, L. B. (1967). Classification and identification of shales. Journal of Soil Mechanics and Foundations Division, 93:97-116. 
Vallabhan, C. V., \& Das, Y. C. (1987). A note on elastic foundations. Texas Technical University, IDR Report.

Vallabhan, C. V., \& Das, Y. C. (1988). A parametric study of beams on elastic foundations. Journal of Engineering Mechanics Division, 114(12):2072-2082.

Vallabhan, C. V., \& Das, Y. C. (1989). Beams on elastic foundations: a new approach. Proceedings of the American Society of Civil Engineers Conference on Foundation Engineering: Current Principles and Practices, Evanston, Illinois.

Van Dyke, M., Sears, M., Klemetti, T., Su, D., Tulu, I., \& Wickline, J. (2018). Geological evaluation of floor heave in a longwall mine under deep overburden. Proceedings of the 52nd US Rock Mechanics and Geomechanics Symposium, Seattle, Washington. (American Society of Rock Mechanics).

Van Eeckhout, E. M. (1976). The mechanisms of strength reduction due to moisture in coal mine shales. International Journal of Rock Mechanics and Mining Sciences and Geomechanics, 13(2):61-67.

Van Eeckhout, E. M., \& Peng, S. S. (1975). The effect of humidity on the compliances of coal mine shales. International Journal of Rock Mechanics and Mining Sciences and Geomechanics, 12(11):335-340.

Vásárhelyi, B., \& Ván, P. (2006). Influence of water content on the strength of rock. Engineering Geology, 84:70-74.

Vasundhara. (1999). Geomechanical behavior of soft floor strata in underground coal mines. PhD thesis, University of New South Wales, Sydney, Australia.

Venkateswarlu, V. (1986). Geomechanics classification of coal measure rocks vis-a-vis roof supports. In Z. T. Bieniawski, Engineering rock mass classification. (John Wiley and Sons).

Vesic, A. S. (1973). Analysis of ultimate loads of shallow foundations. Journal of Soil Mechanics and Foundation Division, 99(1):45-73. 
Vlasov, V. Z., \& Leont'ev, N. N. (1966). Beams, plates, and shells on elastic foundations. Translated from Russian, Israel Program for Scientific Translations.

Von Preinl, Z. B., Tamames, B. C., Fernandéz, J. G., \& Hernandéz, M. Á. (2006). Rock mass excavability indicator: New way to selecting the optimum tunnel construction method. Underground Space Technology, 21(3):237-237.

Wakim, J., Hadj-Hassen, F., Tijani, M., \& Noirel, J.-F. (2005). Effect of water on the mechanical behaviour of shales. Proceedings of the Post-Mining 2005 Conference, pp 1-12, Nancy, France. The Research Group for the Impact and Safety of Underground Works (GISOS).

Wang, Y. (1996). Mechanisms and control of mine floor heave. PhD thesis, West Virginia University.

West, G. (1994). Effect of suction on the strength of rock. Quarterly Journal of Engineering Geology and Hydrogeology, 27(1):51-56.

Whiteley, B., Vasundhara, \& Sainsbury, B.-A. L. (2005). Systems approach to pillar design, module 2: long term stability flooded mine workings above claystone floors. ACARP Project C9018 Final Report (Australian Coal Association Research Program).

Whittles, D. N. (1999). The application of rock mass classification principles to coal mine design. PhD thesis, University of Nottingham, United Kingdom.

Whittles, D., Reddish, D., \& Lowndes, I. (2007). The development of a coal measure classification (CMC) and its use for prediction of geomechanical parameters. International Journal of Rock Mechanics and Mining Sciences, 44(4):496-513.

Wickham, G. E., Tiedeman, H. R., \& Skinner, E. H. (1972). Support determination based on geological predictions. Proceedings of the North American Rapid Excavation and Tunneling Conference, pp 43-64, New York. (American Society of Mechanical Engineers).

Winkler, E. (1864). Die Lehre von der Elastizitt und Festigkeit (Theory of Elasticity and Strength) (H. Dominicus). 
Wuest, J. (1992). Controlling coal mine floor heave: an overview. U.S. Department of the Interior, Bureau of Mines, Washington, D.C.

Wuest, W. J., DeMarco, M. J., \& Mark, C. (1996). Review of applications of the Coal Mine Roof Rating (CMRR) for ground control planning and operations. Mining Engineering, 48(7):49-55.

WVGES. (2020). West Virginia Geological and Ecological Survey, West Virginia Earth Science Studies: Geology of the New River Gorge. Retrieved 10 19, 2020, from https://www.wvgs.wvnet.edu/www/geology/geoles01.htm.

Yagiz, S. (2002). Development of rock fracture and brittleness indices to quantify the effects of rock mass features and toughness in the CSM Model basic penetration for hard rock tunneling machines. PhD thesis, Colorado School of Mines, Colorado.

Yagiz, S. (2008). Utilizing rock mass properties for predicting TBM performance in hard rock conditions. Tunnelling and Underground Space Technology, 23(3):326-339.

Yilmaz, I. (2010). Influence of water content on the strength and deformability of gypsum. International Journal of Rock Mechanics and Mining Sciences, 47(2):342-347.

Young, C. M. (1917). Percentage of extraction bituminous coal with special reference to Illinois conditions. Bulletin of University of Illinois Engineering Experiment Station, No 100, p 175.

Zhang, S., Bei, Z., \& Zhang, Y. F. (2011). The causes analysis and control measures about rapid floor heave in deep mine. Applied Mechanics and Materials .

Zhu, S., Feng, Y., \& Jiang, F. (2016). Determination of abutment pressure in coal mines with extremely thick alluvium stratum: a typical kind of rockburst mines in China. Rock Mechanics and Rock Engineering, 49(5):1943-1952. 


\section{APPENDIX A}

Table A.1. Common coal mine roof rock strength values (Molinda and Mark, 1996).

\begin{tabular}{|c|c|c|c|c|c|c|c|}
\hline \multirow{2}{*}{$\begin{array}{c}\text { Ferm } \\
\text { No. }\end{array}$} & \multirow[t]{2}{*}{ Lithological Description } & \multicolumn{2}{|c|}{ Axial Strength (MPa) } & \multicolumn{2}{|c|}{$\begin{array}{c}\text { Diametral Strength } \\
\text { (MPa) }\end{array}$} & \multirow[t]{2}{*}{ State } & \multirow{2}{*}{$\begin{array}{c}\text { Average } \\
\text { UR }\end{array}$} \\
\hline & & Average & Std. Dev. & Average & Std. Dev. & & \\
\hline 14 & Slumped sandy shale & & & & & PA & 35 \\
\hline 20 & Coal & 12 & 5 & 6 & 2 & WY,PA,KY,WV & 35 \\
\hline 113 & Black shale with coal streaks & 34 & 7 & 5 & 2 & OH,PA & 35 \\
\hline 114 & Black shale & 44 & 29 & 10 & 6 & IL,PA & 39 \\
\hline 119 & Black shale with fossil shells & 18 & 6 & 9 & 4 & KY & 39 \\
\hline 122 & Dark gray layered shale & 53 & 20 & 25 & 31 & WV,PA & 45 \\
\hline 123 & Dark gray shale with coal streaks & 36 & 9 & 9 & 4 & $\mathrm{PA}, \mathrm{WV}, \mathrm{OH}$ & 33 \\
\hline 124 & Dark gray shale & 36 & 28 & 8 & 4 & $\mathrm{PA}, \mathrm{WY}, \mathrm{KY}$ & 36 \\
\hline 127 & Dark gray fireclay & - & - & 9 & 6 & $\mathrm{PA}, \mathrm{OH}, \mathrm{WV}$ & 30 \\
\hline 137 & Light gray green fireclay & 33 & 45 & 6 & - & KY & 28 \\
\hline 147 & Green claystone & - & - & - & - & $\mathrm{OH}, \mathrm{PA}$ & 30 \\
\hline 237 & $\begin{array}{l}\text { Light gray green fireclay with limestone } \\
\text { nodules }\end{array}$ & 64 & 24 & 16 & - & PA & - \\
\hline 322 & Dark gray shale and interbedded sandstone & 78 & 27 & 17 & 9 & WV,PA & 48 \\
\hline 323 & Dark gray shale with sandstone streaks & 48 & 24 & 11 & 5 & $\mathrm{PA}, \mathrm{KY}$ & 40 \\
\hline 324 & Dark gray massive sandy shale & 55 & 15 & 9 & 5 & WV,PA,IL,KY & 47 \\
\hline 325 & Dark gray massive churned sandy shale & 42 & 11 & 13 & 11 & WV,PA & 48 \\
\hline 327 & Dark gray sandy fireclay & 9 & 1 & - & - & KY & 29 \\
\hline 332 & $\begin{array}{l}\text { Light gray green shale and interbedded } \\
\text { sandstone }\end{array}$ & 32 & 10 & 10 & 6 & IL,WY,KY & 44 \\
\hline 337 & Light gray green sandy fireclay & 41 & 8 & 39 & 30 & PA & - \\
\hline 357 & Red and green sandy claystone & 64 & 43 & - & - & PA & - \\
\hline 437 & $\begin{array}{l}\text { Light gray green sandy fireclay with limestone } \\
\text { nodules }\end{array}$ & 12 & 4 & 5 & 2 & PA & - \\
\hline
\end{tabular}


Gray crossbedded sandstone

Gray sandstone with shale streaks, rippled

Gray massive sandstone

Gray sandstone with coal spars

Hard quartz pebble conglomerate

Shale breccia

Shale pebble shaley limestone breccia

Layered fine-grained shaley limestone

Massive fine-grained shaley limestone

Massive fine-grained shaley limestone

Fine-grained shale limestone with limestone nodules

Massive fine-grained sandstone

Nodular fine-grained limestone

Massive fine-grained limestone with fossil shells

\begin{tabular}{cccccc}
61 & 5 & 24 & 13 & PA,KY,WY & 63 \\
80 & 48 & 28 & 14 & OH,PA,WY,KY,WV & 63 \\
75 & 27 & 94 & 38 & WV,KY,PA & 77 \\
- & - & - & - & WV,OH & 43 \\
98 & 23 & 67 & 35 & PA & 46 \\
22 & 2 & - & - & - & - \\
- & - & - & - & KY & 78 \\
78 & 14 & 15 & 4 & OH & 63 \\
61 & 32 & 41 & 30 & - & - \\
30 & 16 & 14 & 3 & KY & 35 \\
39 & 30 & 9 & 2 & - & - \\
126 & 38 & 127 & 23 & OH & 100 \\
- & - & - & - & OH & 94 \\
114 & 34 & 83 & - & - & - \\
\hline
\end{tabular}


Table A.2. CMFR Calculation.

\begin{tabular}{|c|c|c|c|c|c|c|c|c|c|c|}
\hline $\begin{array}{l}\text { Mine } \\
\text { Name }\end{array}$ & $\begin{array}{c}\text { Borehole } \\
\text { Name }\end{array}$ & $\begin{array}{c}\text { Failure or } \\
\text { Non- } \\
\text { failure } \\
\end{array}$ & $\begin{array}{c}\text { Immediate Floor } \\
\text { Lithological Description }\end{array}$ & $\begin{array}{c}\text { Thickness } \\
\text { (m) }\end{array}$ & (MPa) & $\begin{array}{c}\text { UCS } \\
\text { Rating }\end{array}$ & $\begin{array}{l}\text { Discontinuity } \\
\text { Spacing } \\
\text { Interval }\end{array}$ & $\begin{array}{l}\text { Discontinuity } \\
\text { Spacing } \\
\text { Rating }\end{array}$ & $\begin{array}{c}\text { Unit } \\
\text { Rating }\end{array}$ & CMFR \\
\hline \multirow{3}{*}{ A } & \multirow{3}{*}{ BH 1} & \multirow{3}{*}{ Failure } & Dark gray fireclay & 2.03 & 59.29 & 48.79 & 60 to 200 & 15 & 63.79 & \multirow{3}{*}{68} \\
\hline & & & Dark gray sandy fireclay & 0.40 & 100.66 & 57.58 & 60 to 200 & 15 & 72.58 & \\
\hline & & & Gray crossbedded ss & 0.58 & 139.96 & 62.50 & 60 to 200 & 15 & 77.50 & \\
\hline \multirow{6}{*}{ A } & \multirow{6}{*}{ BH 2} & \multirow{6}{*}{ Failure } & Fireclay & 0.11 & N/A & N/A & 20 to 60 & 5 & 40.00 & \multirow{6}{*}{68} \\
\hline & & & Dark gray shale & 0.23 & 55.16 & 47.55 & 20 to 60 & 5 & 52.55 & \\
\hline & & & Sandy fireclay & 1.23 & 108.25 & 58.53 & 60 to 200 & 15 & 73.53 & \\
\hline & & & Dark gray shale & 0.75 & 88.94 & 56.12 & 20 to 60 & 5 & 61.12 & \\
\hline & & & Shale & 0.03 & 244.07 & 65.00 & 20 to 60 & 5 & 70.00 & \\
\hline & & & Dark gray shale & 0.65 & 105.49 & 58.19 & 60 to 200 & 15 & 73.19 & \\
\hline \multirow{3}{*}{$\mathrm{A}$} & \multirow{3}{*}{ BH 3} & \multirow{3}{*}{ Failure } & Dark gray fireclay & 0.40 & 55.16 & 47.55 & 20 to 60 & 5 & 52.55 & \multirow{3}{*}{75} \\
\hline & & & Sandy fireclay & 0.91 & 93.08 & 56.64 & 60 to 200 & 15 & 71.64 & \\
\hline & & & Dark gray shale w/ss str. & 1.69 & 93.08 & 56.64 & 200 to 600 & 25 & 81.64 & \\
\hline \multirow{3}{*}{ A } & \multirow{3}{*}{ BH 4} & \multirow{3}{*}{$\begin{array}{l}\text { Non- } \\
\text { failure }\end{array}$} & Dark gray fireclay & 2.03 & 59.29 & 48.79 & 60 to 200 & 15 & 63.79 & \multirow{3}{*}{68} \\
\hline & & & Dark gray sandy fireclay & 0.40 & 100.66 & 57.58 & 60 to 200 & 15 & 72.58 & \\
\hline & & & Gray crossbedded ss & 0.58 & 139.96 & 62.50 & 60 to 200 & 15 & 77.50 & \\
\hline \multirow{6}{*}{ A } & \multirow{6}{*}{ BH 5} & \multirow{6}{*}{$\begin{array}{l}\text { Non- } \\
\text { failure }\end{array}$} & Fireclay & 0.11 & N/A & N/A & 20 to 60 & 5 & 40.00 & \multirow{6}{*}{67} \\
\hline & & & Dark gray shale & 0.23 & 55.16 & 47.55 & 20 to 60 & 5 & 52.55 & \\
\hline & & & Sandy fireclay & 1.23 & 108.25 & 58.53 & 60 to 200 & 15 & 73.53 & \\
\hline & & & Dark gray shale & 0.75 & 88.94 & 56.12 & 20 to 60 & 5 & 61.12 & \\
\hline & & & Shale & 0.03 & 244.07 & 65.00 & 20 to 60 & 0 & 65.00 & \\
\hline & & & Dark gray shale & 0.65 & 105.49 & 58.19 & 60 to 200 & 15 & 73.19 & \\
\hline
\end{tabular}




\begin{tabular}{|c|c|c|c|c|c|c|c|c|c|c|}
\hline \multirow{3}{*}{ A } & \multirow{3}{*}{ BH 6} & \multirow{3}{*}{$\begin{array}{l}\text { Non- } \\
\text { failure }\end{array}$} & Dark gray fireclay & 0.40 & 55.16 & 47.55 & 20 to 60 & 5 & 52.55 & \multirow{3}{*}{75} \\
\hline & & & Sandy fireclay & 0.91 & 93.08 & 56.64 & 60 to 200 & 15 & 71.64 & \\
\hline & & & Dark gray shale w/ss str. & 1.69 & 93.08 & 56.64 & 200 to 600 & 25 & 81.64 & \\
\hline \multirow{5}{*}{ A } & \multirow{5}{*}{ BH 7} & \multirow{5}{*}{$\begin{array}{l}\text { Non- } \\
\text { failure }\end{array}$} & Dark shale & 0.12 & N/A & N/A & $<20$ & 0 & 40.00 & \multirow{5}{*}{71} \\
\hline & & & Sandy fireclay & 1.20 & 79.29 & 54.79 & 60 to 200 & 15 & 69.79 & \\
\hline & & & Gray sandstone & 0.29 & 105.49 & 58.19 & 60 to 200 & 15 & 73.19 & \\
\hline & & & Sandy fireclay & 0.43 & 88.94 & 56.12 & 60 to 200 & 15 & 71.12 & \\
\hline & & & Gray sandstone & 0.96 & 122.73 & 60.34 & 60 to 200 & 15 & 75.34 & \\
\hline \multirow{4}{*}{ A } & \multirow{4}{*}{ ВН 8} & \multirow{4}{*}{$\begin{array}{l}\text { Non- } \\
\text { failure }\end{array}$} & Dark gray fireclay & 0.24 & 49.0 & 45.69 & 20 to 60 & 5 & 50.69 & \multirow{4}{*}{74} \\
\hline & & & Dark gray sandy fireclay & 0.67 & 57.9 & 48.38 & 60 to 200 & 15 & 63.38 & \\
\hline & & & Sandstone w/shale str. & 1.60 & 192.4 & 65.00 & 60 to 200 & 15 & 80.00 & \\
\hline & & & Dark gray sandy shale & 0.48 & 192.4 & 65.00 & 60 to 200 & 15 & 80.00 & \\
\hline \multirow{5}{*}{ A } & \multirow{5}{*}{ ВН 9} & \multirow{5}{*}{$\begin{array}{l}\text { Non- } \\
\text { failure }\end{array}$} & Dark shale & 0.11 & 77.91 & 54.37 & 20 to 60 & 5 & 59.37 & \multirow{5}{*}{85} \\
\hline & & & Dark gray fireclay & 0.12 & 82.74 & 55.34 & 60 to 200 & 15 & 70.34 & \\
\hline & & & Dark gray sandy fireclay & 0.34 & 148.24 & 63.53 & 60 to 200 & 15 & 78.53 & \\
\hline & & & Gray sandstone & 2.39 & 145.48 & 63.19 & 200 to 600 & 25 & 88.19 & \\
\hline & & & Sandstone w/shale str. & 0.04 & 160.65 & 65.00 & 200 to 600 & 25 & 90.00 & \\
\hline \multirow{4}{*}{ A } & \multirow{4}{*}{ BH 10} & \multirow{4}{*}{$\begin{array}{l}\text { Non- } \\
\text { failure }\end{array}$} & Fireclay & 0.91 & 79.29 & 54.79 & 20 to 60 & 5 & 59.79 & \multirow{4}{*}{70} \\
\hline & & & Sandy fireclay & 1.08 & 117.21 & 59.65 & 60 to 200 & 15 & 74.65 & \\
\hline & & & Dark shale & 0.73 & 110.32 & 58.79 & 60 to 200 & 15 & 73.79 & \\
\hline & & & Dark gray shale w/ss str. & 0.28 & 149.62 & 63.70 & 60 to 200 & 15 & 78.70 & \\
\hline \multirow{3}{*}{ A } & \multirow{3}{*}{ BH 11} & \multirow{3}{*}{$\begin{array}{l}\text { Non- } \\
\text { failure }\end{array}$} & Dark gray fireclay & 0.88 & 56.54 & 47.96 & 60 to 200 & 15 & 62.96 & \multirow{3}{*}{68} \\
\hline & & & Dark gray sandy fireclay & 0.62 & 86.18 & 55.77 & 60 to 200 & 15 & 70.77 & \\
\hline & & & Dark gray shale w/ss str. & 1.49 & 83.43 & 55.43 & 60 to 200 & 15 & 70.43 & \\
\hline \multirow{5}{*}{ A } & \multirow{5}{*}{ BH 12} & \multirow{5}{*}{$\begin{array}{l}\text { Non- } \\
\text { failure }\end{array}$} & Dark shale & 0.12 & N/A & N/A & $<20$ & 0 & 40.00 & \multirow{5}{*}{72} \\
\hline & & & Dark gray sandy fireclay & 0.72 & 46.19 & 44.86 & 60 to 200 & 15 & 59.86 & \\
\hline & & & Dark gray intb ss and shale & 1.22 & 180.64 & 65.00 & 60 to 200 & 15 & 80.00 & \\
\hline & & & Dark gray shale w/ss str & 0.21 & 93.77 & 56.72 & 20 to 60 & 5 & 61.72 & \\
\hline & & & Gray sandstone w/shale str & 0.74 & 179.26 & 65.00 & 60 to 200 & 15 & 80.00 & \\
\hline
\end{tabular}




\begin{tabular}{|c|c|c|c|c|c|c|c|c|c|c|}
\hline \multirow{5}{*}{ A } & \multirow{5}{*}{ BH 13} & \multirow{5}{*}{$\begin{array}{l}\text { Non- } \\
\text { failure }\end{array}$} & Dark gray shale & 0.30 & N/A & N/A & 20 to 60 & 5 & 40.00 & \multirow{5}{*}{73} \\
\hline & & & Gray fireclay & 0.17 & 90.32 & 56.29 & 20 to 60 & 5 & 61.29 & \\
\hline & & & Dark sandy fireclay & 0.76 & 93.77 & 56.72 & 60 to 200 & 15 & 71.72 & \\
\hline & & & Dark gray shale w/ss str. & 1.24 & 156.51 & 64.56 & 60 to 200 & 15 & 79.56 & \\
\hline & & & Gray sandstone w/shale str. & 0.52 & 164.78 & 65.00 & 60 to 200 & 15 & 80.00 & \\
\hline \multirow{4}{*}{ A } & \multirow{4}{*}{ BH 14} & \multirow{4}{*}{$\begin{array}{l}\text { Non- } \\
\text { failure }\end{array}$} & Dark gray fireclay & 0.52 & 55.16 & 47.55 & 20 to 60 & 5 & 52.55 & \multirow{4}{*}{61} \\
\hline & & & Dark gray sandy fireclay & 1.15 & 60.67 & 49.20 & 20 to 60 & 5 & 54.20 & \\
\hline & & & Dark gray shale w/ss str. & 1.08 & 128.93 & 61.12 & 60 to 200 & 15 & 76.12 & \\
\hline & & & Dark shale & 0.25 & 96.53 & 57.07 & 60 to 200 & 15 & 72.07 & \\
\hline \multirow{6}{*}{ B } & \multirow{6}{*}{ BH 15} & \multirow{6}{*}{$\begin{array}{l}\text { Non- } \\
\text { failure }\end{array}$} & Dark gray fireclay & 0.47 & 31.78 & 40.54 & 60 to 200 & 15 & 55.54 & \multirow{6}{*}{63} \\
\hline & & & Dark gray shale w/ss str & 0.68 & 48.00 & 45.40 & 60 to 200 & 15 & 60.40 & \\
\hline & & & Dark gray shale w/ss str & 0.79 & 48.00 & 45.40 & 60 to 200 & 15 & 60.40 & \\
\hline & & & Dark gray massive sandy sh & 0.53 & 55.00 & 47.50 & 200 to 600 & 25 & 72.50 & \\
\hline & & & Gray sandstone w/shale str. & 0.12 & 80.00 & 55.00 & 20 to 60 & 5 & 60.00 & \\
\hline & & & Gray sandstone w/shale str. & 0.42 & 80.00 & 55.00 & 60 to 200 & 15 & 70.00 & \\
\hline \multirow{6}{*}{ B } & \multirow{6}{*}{ BH 16} & \multirow{6}{*}{$\begin{array}{l}\text { Non- } \\
\text { failure }\end{array}$} & Massive dark gray shale & 0.56 & 43.23 & 43.97 & 60 to 200 & 15 & 58.97 & \multirow{6}{*}{71} \\
\hline & & & Massive dark gray shale & 0.55 & 59.61 & 48.88 & 200 to 600 & 25 & 73.88 & \\
\hline & & & Gray ripple ss w/shale str. & 0.57 & 104.20 & 58.03 & 200 to 600 & 25 & 83.03 & \\
\hline & & & Gray ripple ss w/shale str. & 0.58 & 88.45 & 56.06 & 60 to 200 & 15 & 71.06 & \\
\hline & & & Gray ripple ss w/shale str. & 0.58 & 66.24 & 50.87 & 60 to 200 & 15 & 65.87 & \\
\hline & & & Gray ripple ss w/shale ss & 0.15 & 80.00 & 55.00 & 60 to 200 & 15 & 70.00 & \\
\hline \multirow{7}{*}{ B } & \multirow{7}{*}{ BH 17} & \multirow{7}{*}{$\begin{array}{l}\text { Non- } \\
\text { failure }\end{array}$} & Dark gray fireclay & 0.32 & $\mathrm{~N} / \mathrm{A}$ & $\mathrm{N} / \mathrm{A}$ & $<20$ & 0 & 40.00 & \multirow{7}{*}{70} \\
\hline & & & Dark gray fireclay & 0.14 & N/A & N/A & $<20$ & 0 & 40.00 & \\
\hline & & & Dark gray fireclay & 0.15 & N/A & N/A & $<20$ & 0 & 40.00 & \\
\hline & & & Gray ripple ss w/shale str. & 0.48 & 150.95 & 63.87 & 200 to 600 & 25 & 88.87 & \\
\hline & & & Dark gray sandy shale & 0.89 & 122.95 & 60.37 & 60 to 200 & 15 & 75.37 & \\
\hline & & & Dark gray sandy shale & 0.61 & 137.03 & 62.13 & 200 to 600 & 25 & 87.13 & \\
\hline & & & Gray sandy shale & 0.40 & 137.00 & 62.13 & 60 to 200 & 15 & 77.13 & \\
\hline \multirow{3}{*}{ B } & \multirow{3}{*}{ BH 18} & \multirow{3}{*}{$\begin{array}{l}\text { Non- } \\
\text { failure }\end{array}$} & Gray sandstone & 0.47 & 103.64 & 57.95 & 60 to 200 & 15 & 72.95 & \multirow{3}{*}{70} \\
\hline & & & Gray sandstone & 0.40 & 90.93 & 56.37 & 60 to 200 & 15 & 71.37 & \\
\hline & & & Gray sandstone & 2.14 & 75.00 & 53.50 & 60 to 200 & 15 & 68.50 & \\
\hline
\end{tabular}




\begin{tabular}{|c|c|c|c|c|c|c|c|c|c|c|}
\hline \multirow{4}{*}{ B } & \multirow{4}{*}{ BH 19} & \multirow{4}{*}{$\begin{array}{l}\text { Non- } \\
\text { failure }\end{array}$} & Dark gray fireclay & 0.27 & 42.84 & 43.85 & 60 to 200 & 15 & 58.85 & \multirow{4}{*}{61} \\
\hline & & & Dark gray sandy fireclay & 0.23 & N/A & N/A & 60 to 200 & 15 & 40.00 & \\
\hline & & & Massive gray sandstone & 0.63 & 59.19 & 48.76 & 60 to 200 & 15 & 63.76 & \\
\hline & & & Gray sandstone & 1.87 & 59.19 & 48.76 & 60 to 200 & 15 & 63.76 & \\
\hline \multirow{3}{*}{ B } & \multirow{3}{*}{ BH 20} & \multirow{3}{*}{$\begin{array}{l}\text { Non- } \\
\text { failure }\end{array}$} & Dark gray fireclay & 0.25 & 45.20 & 44.56 & 60 to 200 & 15 & 59.56 & \multirow{3}{*}{68} \\
\hline & & & Gray rooted sandstone & 0.31 & 79.88 & 54.96 & 60 to 200 & 15 & 69.96 & \\
\hline & & & Gray massive sandstone & 2.44 & 75.00 & 53.50 & 60 to 200 & 15 & 68.50 & \\
\hline \multirow{4}{*}{$\mathrm{C}$} & \multirow{4}{*}{ BH 21} & \multirow{4}{*}{ Failure } & Shale/ silty shale & 0.30 & 36.00 & 41.80 & 20 to 60 & 5 & 46.80 & \multirow{4}{*}{52} \\
\hline & & & Sandy shale & 0.55 & 55.00 & 47.50 & 60 to 200 & 15 & 62.50 & \\
\hline & & & Shale & 1.66 & 36.00 & 41.80 & 20 to 60 & 5 & 46.80 & \\
\hline & & & Dark shale w/coal str. & 0.49 & 55.00 & 47.50 & 60 to 200 & 15 & 62.50 & \\
\hline \multirow{4}{*}{$\mathrm{C}$} & \multirow{4}{*}{ BH 22} & \multirow{4}{*}{ Failure } & Shale/ silty shale & 0.30 & 36.00 & 41.80 & 20 to 60 & 5 & 46.80 & \multirow{4}{*}{52} \\
\hline & & & Sandy shale & 0.55 & 55.00 & 47.50 & 60 to 200 & 15 & 62.50 & \\
\hline & & & Shale & 1.66 & 36.00 & 41.80 & 20 to 60 & 5 & 46.80 & \\
\hline & & & Dark shale w/coal str. & 0.49 & 55.00 & 47.50 & 60 to 200 & 15 & 62.50 & \\
\hline \multirow{2}{*}{$\mathrm{C}$} & \multirow{2}{*}{ BH 23} & \multirow{2}{*}{$\begin{array}{l}\text { Non- } \\
\text { failure }\end{array}$} & Sandy shale & 0.05 & 55 & 47.50 & 60 to 200 & 15 & 62.50 & \multirow{2}{*}{63} \\
\hline & & & Shale w/ss str. & 2.95 & 55 & 47.50 & 60 to 200 & 15 & 62.50 & \\
\hline \multirow{2}{*}{ C } & \multirow{2}{*}{ BH 24} & \multirow{2}{*}{$\begin{array}{c}\text { Non- } \\
\text { failure }\end{array}$} & Sandy shale & 0.05 & 55 & 47.50 & 60 to 200 & 15 & 62.50 & \multirow{2}{*}{63} \\
\hline & & & Shale w/ss str. & 2.95 & 55 & 47.50 & 60 to 200 & 15 & 62.50 & \\
\hline \multirow{2}{*}{$\mathrm{C}$} & \multirow{2}{*}{ BH 25} & \multirow{2}{*}{$\begin{array}{l}\text { Non- } \\
\text { failure }\end{array}$} & Black shale & 0.43 & 44 & 44.20 & 60 to 200 & 15 & 59.20 & \multirow{2}{*}{62} \\
\hline & & & Sandy shale & 2.57 & 55 & 47.50 & 60 to 200 & 15 & 62.50 & \\
\hline \multirow{2}{*}{$\mathrm{C}$} & \multirow{2}{*}{ BH 26} & Non- & Black shale & 0.43 & 44 & 44.20 & 60 to 200 & 15 & 59.20 & 67 \\
\hline & & failure & Sandy shale & 2.57 & 55 & 47.50 & 60 to 200 & 15 & 62.50 & 62 \\
\hline $\mathrm{n}$ & ВН 27 & Non- & No Recovery & 0.46 & N/A & N/A & 60 to 200 & 15 & 40.00 & 61 \\
\hline $\mathrm{D}$ & ВН 27 & failure & Clay shale & 2.54 & 62.80 & 49.84 & 60 to 200 & 15 & 64.84 & 61 \\
\hline $\mathrm{n}$ & ВН 28 & Non- & No Recovery & 0.46 & N/A & N/A & 60 to 200 & 15 & 25.00 & 66 \\
\hline U & ВН $\angle 8$ & failure & Clay shale & 2.54 & 62.80 & 49.84 & 60 to 200 & 15 & 64.84 & 01 \\
\hline
\end{tabular}


Table A.3. Elastic modulus of rocks for given rock type and UCS (Tulu et.al, 2018).

\begin{tabular}{lcc}
\hline Rock Type & UCS (MPa) & E (GPa) \\
\hline Limestone & 140 & 31.51 \\
& 100 & 26.86 \\
Sandstone & 80 & 24.54 \\
& 120 & 23.32 \\
& 100 & 20.46 \\
Shale & 80 & 17.60 \\
& 60 & 14.74 \\
& 40 & 11.88 \\
& 80 & 17.60 \\
& 60 & 14.74 \\
& 40 & 11.88 \\
& 30 & 10.45 \\
& 20 & 9.02 \\
& 10 & 7.59 \\
& 5 & 6.88 \\
\hline
\end{tabular}

